AUTARQUIA ASSOCIADA À UNIVERSIDADE DE SÃO PAULO

\title{
BASES DE PROJETO PARA A AUTOMATIZAÇÃO DO SISTEMA DE GARANTIA DA QUALIDADE EM GERÊNCIA DE REJEITOS RADIOATIVOS
}

\author{
RICARDO BASTOS SMITH
}

Dissertação apresentada como parte dos requisitos para obtenção do Grau de Mestre em Ciências na Área de Tecnologia Nuclear - Aplicações

Orientador:

Prof. Dr. Roberto Vicente 
INSTITUTO DE PESQUISAS ENERGÉTICAS E NUCLEARES

Autarquia associada à Universidade de São Paulo

\section{BASES DE PROJETO PARA A AUTOMATIZAÇÃO DO SISTEMA DE GARANTIA DA QUALIDADE EM GERÊNCIA DE REJEITOS RADIOATIVOS}

RICARDO BASTOS SMITH

Dissertação apresentada como parte dos
requisitos para obtenção do Grau de
Mestre em Ciências na Área
de Tecnologia Nuclear - Aplicações
Orientador:

Prof. Dr. Roberto Vicente

Versão Corrigida

Versão Original disponível no IPEN

São Paulo

2018 
Autorizo a reprodução e divulgação total ou parcial deste trabalho, para fins de estudo e pesquisa, desde que citada a fonte

Como citar:

$\mathrm{SMITH}, \mathrm{R}$. B. Bases de projeto para a automatização do sistema de garantia a qualidade em gerência de rejeitos radioativos. 2018. 159 p. Dissertação (Mestrado em Tecnologia Nuclear), Instituto de Pesquisas Energéticas e Nucleares, IPEN-CNEN/SP, São Paulo. Disponível em: <www.teses.usp.br> (data de consulta no formato: $\mathrm{dd} / \mathrm{mm} / \mathrm{aaaa})$

Ficha catalográfica elaborada pelo Sistema de geração automática da Biblioteca IPEN/USP, com os dados fornecidos pelo(a) autor(a)

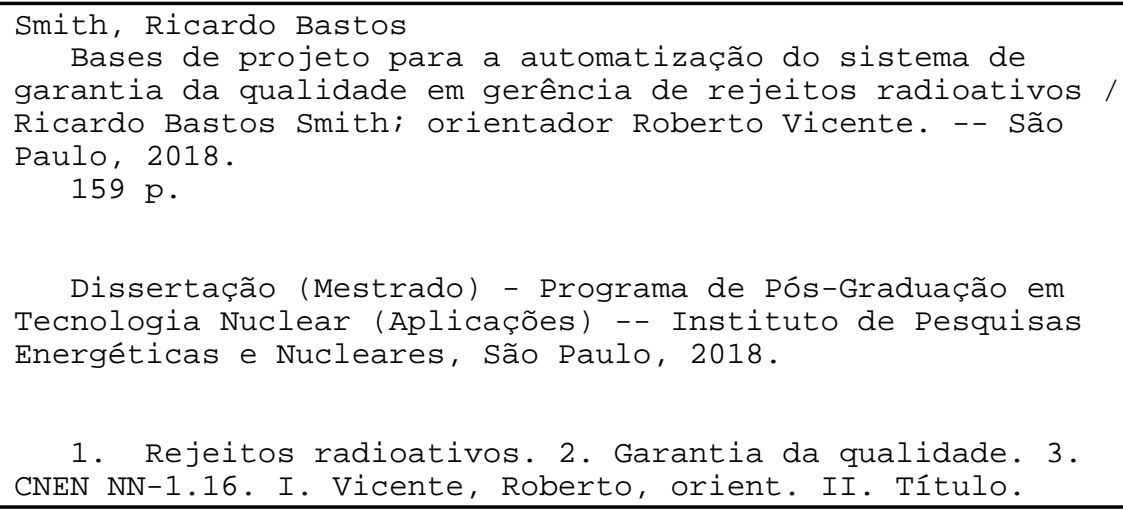




\section{FOLHA DE APROVAÇÃO}

Autor: Ricardo Bastos Smith

Título: Bases de projeto para a automatização do sistema de garantia da qualidade em gerência de rejeitos radioativos

Dissertação apresentada ao Programa de Pós-Graduação em Tecnologia Nuclear da Universidade de São Paulo para obtenção do título de Mestre em Ciências.

Data: 04 / 05 / 2018

\section{Banca examinadora}

Prof. Dr.: Francisco Carlos Paletta

Instituição: FEA-USP/SP

Julgamento: Aprovado

Prof. Dr.: Laís Alencar de Aguiar

Instituição: IRD/RJ

Julgamento: Aprovado

Prof. Dr.: Roberto Vicente

Instituição: IPEN/SP

Julgamento: Aprovado 


\section{AGRADECIMENTOS}

Agradeço primeiro de tudo a esta Força maior que rege a existência, sem a qual nada teria início e realização.

Ao meu orientador Roberto Vicente, que além de extenso conhecimento e possuir uma paciência sui generis para me ouvir e instruir; foi também colega de conversas as mais diversas, de escalas musicais a mensagens via satélite para extraterrestres.

Meus mais sinceros agradecimentos ao Júlio T. Marumo, da Gerência de Rejeitos Radioativos (GRR) do IPEN, que teve um olho clínico para me apontar correções e ajustes diversos a serem feitos em minha dissertação.

Ao Cláudio Dellamano e a toda a equipe do GRR, que em maior ou menor grau auxiliaram em meus estudos.

Ao trio Camila, Regiane e Tereza, colegas de disciplinas e amigas queridas, no IPEN e fora dele.

À Mychelle, que primeiro me inspirou a experimentar este novo caminho nuclear e muito me apoiou, e à sua irmã Luciene, que já me aguentou por alguns anos e por tantos mais aguentar-me-á.

À Comissão Nacional de Energia Nuclear (CNEN), pela bolsa de estudos concedida, número do processo 01341-001688/2016-12.

E a todos que de alguma forma contribuíram para a execução deste trabalho. 


\section{RESUMO}

SMITH, R. B. Bases de projeto para a automatização do sistema de garantia da qualidade em gerência de rejeitos radioativos. 2018. 159 p. Dissertação (Mestrado em Tecnologia Nuclear), Instituto de Pesquisas Energéticas e Nucleares, IPEN-CNEN/SP, São Paulo.

O projeto, operação e descomissionamento de uma unidade de tratamento e armazenamento de rejeitos requerem que sejam observados os requisitos regulatórios referentes à garantia da qualidade nuclear, conforme o Regulamento CNEN-NN-1.16 - "Garantia da Qualidade para a Segurança de Usinas Nucleoelétricas e Outras Instalações", da Comissão Nacional de Energia Nuclear (CNEN). Entretanto, embora a aplicação do regulamento seja obrigatória, o documento da CNEN apresenta requisitos para qualquer tipo de instalação nuclear, sendo por isso genérico e pouco detalhado em relação às ações necessárias para garantir que os requisitos mais específicos de uma unidade de tratamento e armazenamento de rejeitos sejam observados. Além disso, não existem comercialmente ferramentas informatizadas já prontas para utilização, mas somente programas para gestão de qualidade que requerem uma adaptação através da inclusão de conjuntos de dados específicos do programa de controle da qualidade de uma instalação de gestão de rejeitos, ou então o desenvolvimento de uma ferramenta personalizada. Desta forma, o objetivo deste trabalho é buscar informações que permitam o desenvolvimento de bases para um sistema informatizado de garantia da qualidade que esteja em conformidade com o regulamento da CNEN NN-1.16, e que possa vir a englobar os procedimentos específicos para uma instalação de tratamento e gestão de rejeitos radioativos.

Palavras-chave: Rejeitos Radioativos; Garantia da Qualidade; CNEN-NN-1.16. 


\begin{abstract}
SMITH, R. B. Project bases for the automation of a quality assurance system in radioactive waste management. 2018. 159 p. Dissertation (Masters in Nuclear Technology), Nuclear and Energy Research Institute, IPENCNEN/SP, São Paulo.
\end{abstract}

The design, operation and decommissioning of a radioactive waste treatment and storage unit requires the compliance with the regulatory requirements for nuclear quality assurance, in accordance with the CNEN-NN.1.16 - "Quality Assurance for the Safety of Nuclear Power Plants and Other Installations", of the National Nuclear Energy Commission (CNEN). However, although the regulation is mandatory, the CNEN document presents requirements for any type of nuclear facility, therefore it is generic and not detailed in relation to the actions necessary to ensure that the more specific requirements of a radioactive waste treatment and storage unit are met. In addition, there are no commercially available ready-to-use computer tools, but only quality management programs that require adaptation through the inclusion of specific data sets from the quality control program of a radioactive waste management facility, or the development of a customized tool. Therefore, the objective of this work is to gather information that allows the development of bases for a computerized quality assurance system that is in compliance with the CNEN NN-1.16 regulation, and which may include the specific procedures for an facility of treatment and management of radioactive waste.

Keywords: Radioactive Waste; Quality Assurance; CNEN-NN-1.16. 


\section{LISTA DE FIGURAS}

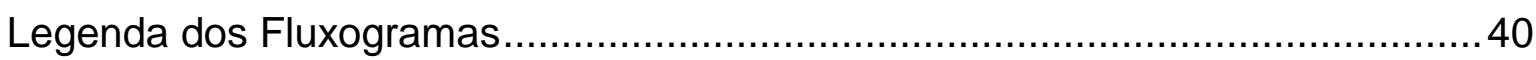

Figura 01 - Fluxograma "Inclusão de Documentos" ........................................... 40

Figura 02 - Fluxograma "Consulta e Edição de Documentos" ..............................42

Figura 03 - Fluxograma "Verificação de Documentos" ........................................ 44

Figura 04 - Fluxograma "Aprovação de Documentos" ......................................... 45

Figura 05 - Fluxograma "Inclusão de Dados de Entrada" ..................................59

Figura 06 - Fluxograma "Consulta e Edição de Dados de Entrada" ......................61

Figura 07 - Fluxograma "Verificação de Dados de Entrada" ................................62

Figura 08 - Fluxograma "Aprovação de Dados de Entrada" ................................... 64

Figura 09 - Fluxograma "Inclusão de Aquisições" ............................................. 75

Figura 10 - Fluxograma "Consulta e Edição de Aquisições" ...............................77

Figura 11 - Fluxograma "Verificação de Aquisições"............................................78

Figura 12 - Fluxograma "Aprovação de Aquisições" .......................................... 80

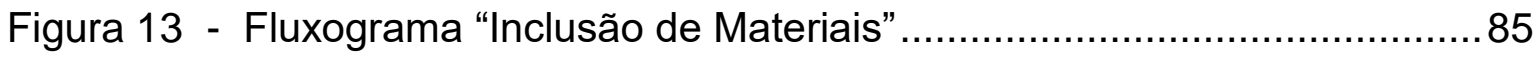

Figura 14 - Fluxograma "Consulta e Edição de Materiais" ................................... 87

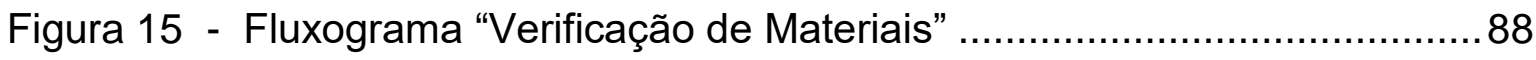

Figura 16 - Fluxograma "Aprovação de Materiais" ............................................ 90

Figura 17 - Fluxograma "Inclusão de Processos"............................................... 94

Figura 18 - Fluxograma "Consulta e Edição de Processos" ................................96

Figura 19 - Fluxograma "Verificação de Processos" .........................................97

Figura 20 - Fluxograma "Aprovação de Processos" .............................................99

Figura 21 - Fluxograma "Inclusão de Inspeções ou Testes" .............................110

Figura 22 - Fluxograma "Consulta e Edição de Inspeções ou Testes"................112

Figura 23 - Fluxograma "Verificação de Inspeções ou Testes" ..........................114

Figura 24 - Fluxograma "Aprovação de Inspeções e Testes"...............................116

Figura 25 - Fluxograma "Inclusão de Itens Não Conformes" ............................120

Figura 26 - Fluxograma "Consulta e Edição de Itens Não Conformes"..............122

Figura 27 - Fluxograma "Verificação de Itens Não Conformes" ........................123

Figura 28 - Fluxograma "Aprovação de Itens Não Conformes".........................125

Figura 29 - Fluxograma "Inclusão de Ações Corretivas" ..................................129

Figura 30 - Fluxograma "Consulta e Edição de Ações Corretivas" ....................131

Figura 31 - Fluxograma "Verificação de Ações Corretivas"...............................132

Figura 32 - Fluxograma "Inclusão de Auditorias" ............................................. 149

Figura 33 - Fluxograma "Consulta e Edição de Auditorias"..................................151 


\section{SUMÁRIO}

INTRODUÇÃO 10

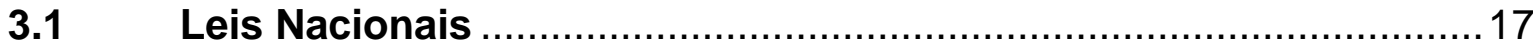

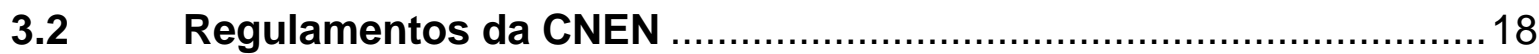

3.3 Manuais da Agência Internacional de Energia Atômica ...................19

3.4 Regulamentação em Outros Países ……..........................................21

3.5 Regulamentação nos Estados Unidos da América .........................23

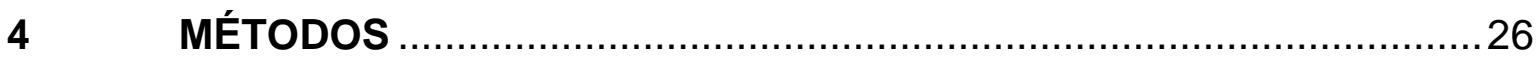

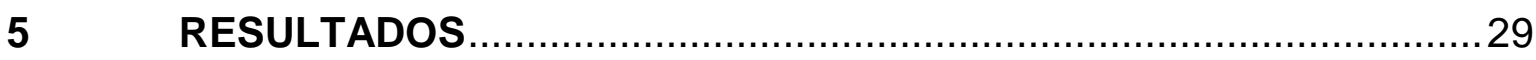

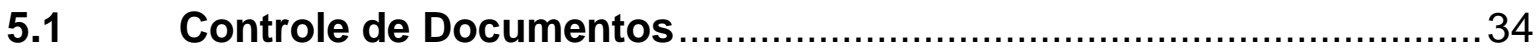

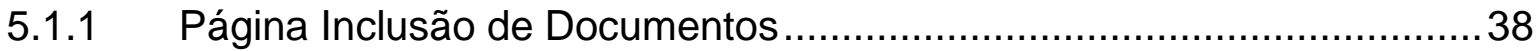

5.1.2 Página Consulta e Edição de Documentos ...........................................40

5.1.3 Página Verificação de Documentos .................................................. 42

5.1.4 Página Aprovação de Documentos ...................................................... 44

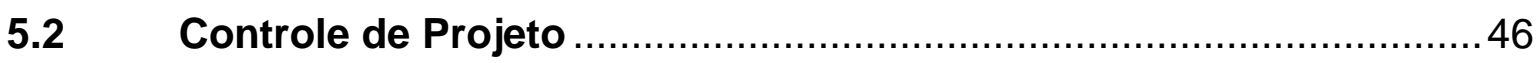

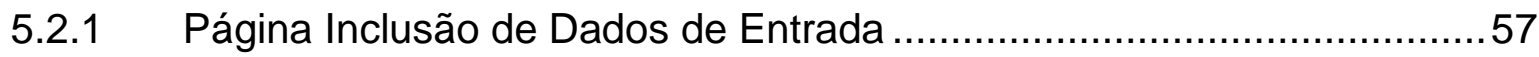

5.2.2 Página Consulta e Edição de Dados de Entrada ...................................59

5.2.3 Página Verificação de Dados de Entrada.............................................. 61

5.2.4 Página Aprovação de Dados de Entrada ............................................... 63

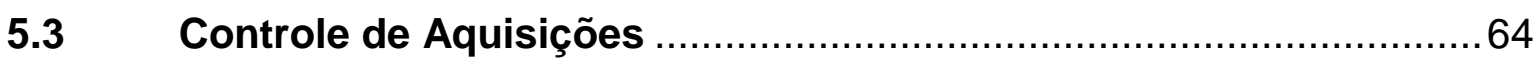

5.3.1 Página Inclusão de Aquisições......................................................... 74

5.3.2 Página Consulta e Edição de Aquisições .............................................. 75

5.3.3 Página Verificação de Aquisições ....................................................77

5.3.4 Página Aprovação de Aquisições ......................................................79

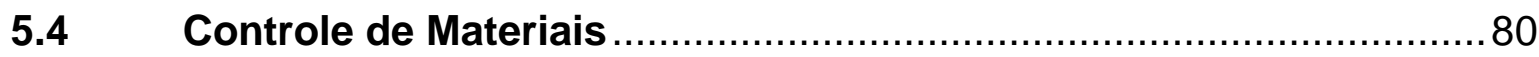

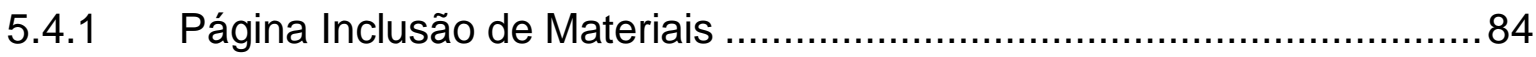

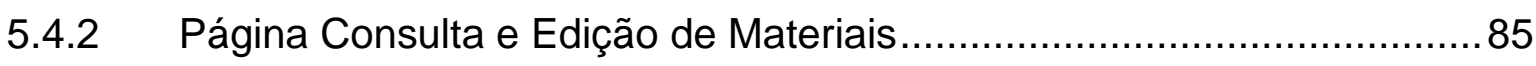

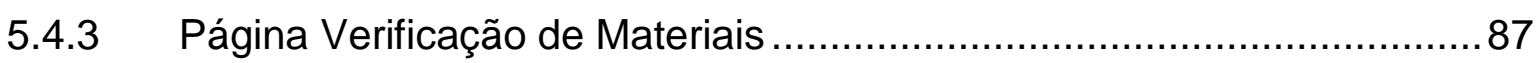

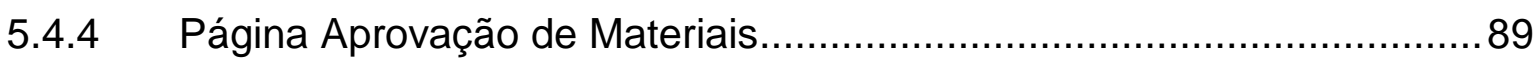

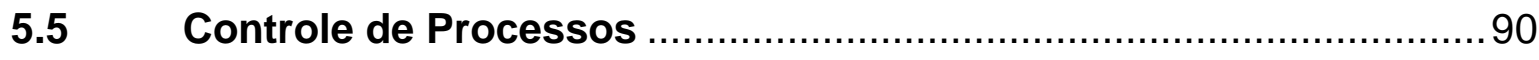

5.5.1 Página Inclusão de Processos ......................................................... 
5.5.2 Página Consulta e Edição de Processos …………………………....... 94

5.5.3 Página Verificação de Processos .....................................................96

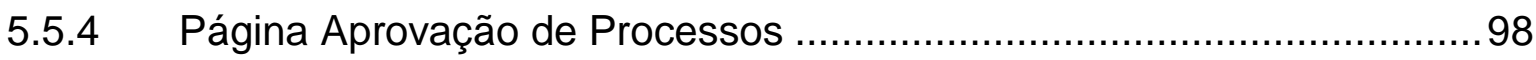

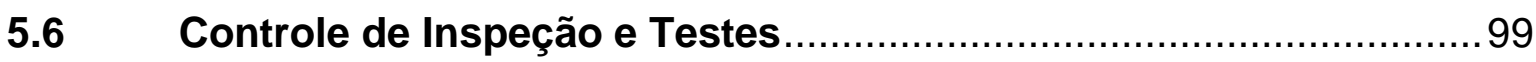

5.6.1 Página Inclusão de Inspeções ou Testes ...........................................109

5.6.2 Página Consulta e Edição de Inspeções ou Testes ...............................111

5.6.3 Página Verificação de Inspeções ou Testes........................................112

5.6.4 Página Aprovação de Inspeções e Testes ........................................114

5.7 Controle de Itens Não Conformes ……..................................116

5.7.1 Página Inclusão de Itens Não Conformes .........................................119

5.7.2 Página Consulta e Edição de Itens Não Conformes ............................120

5.7.3 Página Verificação de Itens Não Conformes....................................... 122

5.7.4 Página Aprovação de Itens Não Conformes ......................................124

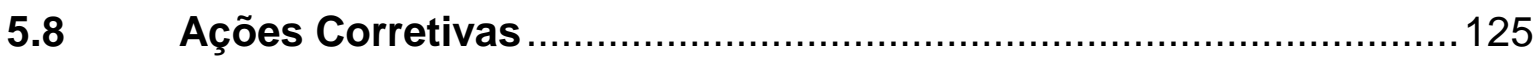

5.8.1 Página Inclusão de Ações Corretivas................................................128

5.8.2 Página Consulta e Edição de Ações Corretivas ....................................129

5.8.3 Página Verificação de Ações Corretivas ............................................ 131

5.9 Registros de Garantia da Qualidade ........................................... 133

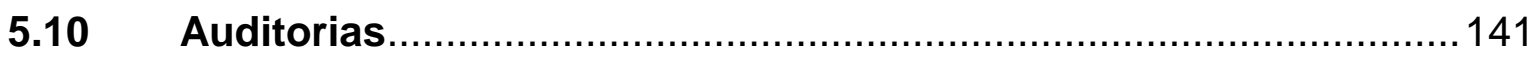

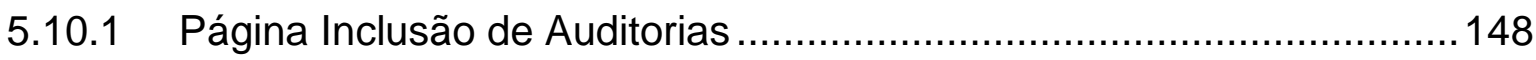

5.10.2 Página Consulta e Edição de informações sobre Auditorias .................149

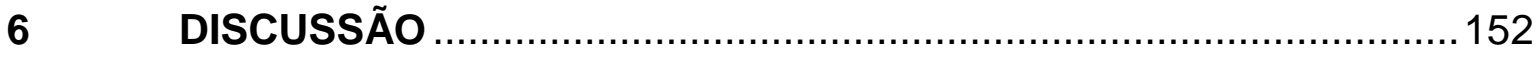

$7 \quad$ CONCLUSÃO

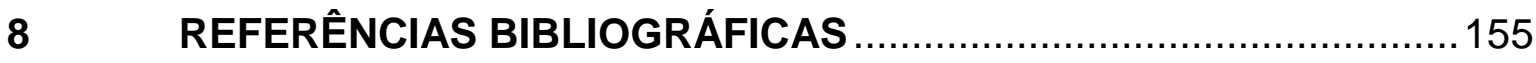




\section{INTRODUÇÃO}

De acordo com a Agência Internacional de Energia Atômica, para efeito regulamentar e legal, o rejeito radioativo é todo aquele que contenha ou esteja contaminado com radionuclídeos em concentrações ou atividades superiores aos limites de isenção estabelecidos pelo órgão regulador correspondente (IAEA, 2003). No Brasil, este órgão regulador é a Comissão Nacional de Energia Nuclear (CNEN), e os limites de isenção são estabelecidos segundo a norma CNEN-NE6.02 (CNEN, 2017).

Os rejeitos radioativos podem ser divididos em rejeitos de alto, médio e baixo níveis de atividade. Segundo a Associação Nuclear Mundial (WNA, 2018), $95 \%$ dos rejeitos são de alta atividade, produzidos em usinas nucleares de energia. Os rejeitos de nível médio são provenientes de filtros usados, componentes de aço do reator, fontes seladas, e alguns efluentes do reprocessamento. Já os rejeitos de baixo nível são compostos por itens levemente contaminados, como ferramentas e roupas de trabalho, provenientes da operação de usinas e outras instalações nucleares. Os rejeitos de baixo nível compõem $90 \%$ do volume total de rejeitos radioativos, mas contêm somente $1 \%$ da radioatividade (WNA, 2018).

Na produção de energia em usinas nucleares, os rejeitos de alto nível ficam guardados em piscinas no próprio local para posterior encaminhamento a depósitos definitivos, enquanto que os rejeitos de média e baixa atividades são armazenados em depósitos intermediários na superfície do planeta; no entanto, estes devem ser tratados visando a sua redução de volume antes do armazenamento.

Para o devido tratamento, devem ser encaminhados a uma instituição licenciada que realize sua gestão de acordo com os padrões recomendados em norma. O termo "gestão de rejeitos", conforme o glossário de termos da Agência Internacional de Energia Atômica, é o conjunto de operações de natureza operacional e administrativa relacionadas com o manuseio, caracterização, tratamento, transporte, armazenamento e deposição dos rejeitos (IAEA, 2003).

Pode-se parecer estranho considerar o rejeito como um produto de alta qualidade; no entanto, termos como "garantia da qualidade" e "controle de produção" são importantes componentes na gestão de rejeitos radioativos; afinal, 
o meio ambiente é um recurso que deve ser protegido. Devido à alta toxicidade de diversos radionuclídeos, a administração dos mesmo após não mais serem aproveitáveis exige um alto nível de controle de qualidade em seu tratamento e armazenamento (LASER, 1991).

No Brasil, pode-se citar como exemplo a Gerência de Rejeitos Radioativos (GRR) do Instituto de Pesquisas Energéticas e Nucleares (IPEN), em São Paulo, que atua como executor da missão constitucional da CNEN de receber e armazenar os rejeitos radioativos gerados pelas instalações radiativas do Brasil, conforme a Lei Federal oㅜ 7781, de 27 de junho de 1989 (BRASIL, 1989). A GRR do IPEN "tem como Missão promover a gestão segura dos rejeitos radioativos gerados no Brasil, dentro dos princípios éticos de proteção ao homem e ao meio ambiente, hoje e no futuro" (IPEN, 2012). As outras instalações da CNEN para gestão de rejeitos radioativos no Brasil são: Instituto de Engenharia Nuclear (IEN), no Rio de Janeiro; Centro de Desenvolvimento da Tecnologia Nuclear (CDTN), em Belo Horizonte; Centro Regional de Ciências Nucleares do Nordeste (CRCN), em Recife; e o Centro Regional do Centro Oeste (CRCO), em Goiânia.

A CNEN é uma autarquia federal vinculada ao Ministério da Ciência, Tecnologia, Inovações e Comunicações (MCTIC), criada e estruturada pela Lei 4.118, de 27 de agosto de 1962 (BRASIL, 1962) para desenvolver a política nacional de energia nuclear. Órgão superior de planejamento, orientação, supervisão e fiscalização, a CNEN estabelece regulamentos em radioproteção e é responsável por regulamentar, licenciar e fiscalizar a produção e o uso da energia nuclear no Brasil (CNEN, 2015).

As operações de tratamento que devem ser realizadas nos processos de gestão, comuns a todos os rejeitos, incluem:

- armazenamento de rejeitos em depósitos iniciais,

- recolhimento de amostras dos diferentes fluxos de rejeito,

- análises radioquímicas das amostras,

- análises radiométricas de embalados de rejeitos,

- transferências e transporte de rejeitos e

- armazenamento de embalados em depósito intermediário. 
Além disso, operações de tratamento específicas para cada tipo incluem:

- compactação de rejeitos sólidos compactáveis;

- fragmentação e encapsulamento em pasta cimento de rejeitos sólidos não compactáveis;

- pré-condicionamento químico de rejeitos líquidos;

- redução de volume de efluentes líquidos por evaporação; e

- imobilização de rejeitos líquidos em cimento.

Alguns dos rejeitos que devem ser gerenciados possuem potencial para causar exposições relevantes do ponto de vista radiológico. Em consequência disso, o projeto de uma instalação de gestão de rejeitos e, depois, sua operação, e por fim o descomissionamento, requererão que sejam observados os requisitos regulatórios referentes à garantia da qualidade nuclear, de acordo com o Regulamento CNEN-NN-1.16 - "Garantia da Qualidade para a Segurança de Usinas Nucleoelétricas e Outras Instalações" (CNEN, 2000) e atendendo à política de coordenação do projeto. É importante lembrar, também, que o Brasil é signatário da Convenção Conjunta para o Gerenciamento Seguro de Combustível Nuclear Usado e dos Rejeitos Radioativos, patrocinado pela Agência Internacional de Energia Nuclear, internalizado no marco legal pátrio pelo Decreto No. 5.935 de 19 de outubro de 2006 e, portanto, deve observar o disposto no Artigo 23 da Convenção que estabelece que

(...) cada Parte Contratante tomará as medidas apropriadas para assegurar que sejam estabelecidos e implementados programas apropriados de garantia da qualidade referentes ao gerenciamento seguro do combustível nuclear usado e de rejeitos radioativos. (BRASIL, 2006).

Os requisitos de garantia da qualidade que foram estabelecidos pela CNEN visam assegurar que as instalações, e o produto resultante da operação delas, cumpram com todos os regulamentos e normas aplicáveis. De acordo com as diretrizes básicas desse regulamento, no desenvolvimento e aplicação do Programa de Garantia da Qualidade (PGQ) devem ser levados em consideração os aspectos técnicos das atividades a serem realizadas, de forma a assegurar a identificação e o cumprimento dos regulamentos da CNEN ou outros órgãos reguladores e as normas e boas práticas de engenharia aplicáveis. 
Além disso, levando-se em conta a natureza da instalação, o regulamento requer que sejam definidos os itens, serviços e processos chamados Itens Importantes para a Segurança (IIS), bem como devem ser delineados os métodos ou níveis apropriados de controle e verificação a serem usados para garantir a qualidade deles. Portanto, uma condição necessária para desenvolver 0 projeto adequadamente é identificar, antecipadamente, as atividades relevantes para a segurança e estabelecer a dependência de cada uma com os requisitos dos regulamentos, normas, etc. de cada processo.

O fim último da observância dos requisitos de garantia da qualidade, no contexto do presente trabalho, e que é obtido com o SGQ, é garantir que o nível apropriado de segurança radiológica e nuclear seja alcançado na construção, operação, descomissionamento e encerramento das instalações de gestão de rejeitos radioativos.

A aplicação dos requisitos de garantia da qualidade é obrigatória no projeto e na operação de uma unidade de gerenciamento de rejeitos radioativos em uma instalação nuclear, motivo pelo qual o documento CNEN-NN-1.16 é tratado aqui como "regulamento". Faz-se o esclarecimento para enfatizar que o SGQ previsto pelo regulamento CNEN-NN-1.16 é de natureza distinta daqueles previstos em normas nacionais e internacionais, tais como as das séries ISO-9000. Enquanto a finalidade da primeira é garantir a segurança nuclear e radiológica de uma instalação, as outras têm como propósito garantir a satisfação dos clientes de um estabelecimento fornecedor de bens ou serviços. Essa última é, portanto, de aplicação opcional por qualquer entidade.

Segundo o Guia de Termos e Expressões utilizados na Normalização da ABNT, o termo "regulamento" é um "documento que contém regras de caráter obrigatório e que é adotado por uma autoridade", enquanto que uma "norma" é um "documento estabelecido por consenso e aprovado por um organismo reconhecido, que fornece, para uso comum e repetitivo, regras, diretrizes ou características para produtos, serviços, processos, sistemas de gestão, pessoas, enfim, nos mais variados campos, e cuja observância não é obrigatória" (ABNT, 2012).

Embora a aplicação do regulamento seja obrigatória, o documento da CNEN apresenta requisitos para qualquer tipo de instalação nuclear, sendo por isso genérico e pouco detalhado em relação às ações necessárias para garantir 
que os requisitos sejam observados. Em particular, a aplicação da regulamentação em uma unidade de tratamento e armazenamento de rejeitos, ainda que muito mais simples do que aquela de uma usina nucleoelétrica, também requer que se estabeleça as bases de projeto com relação à garantia da qualidade. Entende-se por "bases de projeto" o conjunto de condições, necessidades e requisitos levados em consideração no projeto da instalação, na realização do produto ou na implementação de um PGQ e, também, os princípios fundamentais nos quais o projeto é baseado.

O estabelecimento de um PGQ deve levar em consideração que as questões de segurança na gestão dos rejeitos radioativos, em particular da segurança radiológica, possuem dois componentes: a segurança operacional da instalação e a segurança de longo prazo dos rejeitos quando estiverem depositados definitivamente no repositório, chamado de "depósito final" pela Lei Brasileira (BRASIL, 2001). A segurança de longo prazo é alcançada fazendo com que os rejeitos tratados na instalação cumpram com os critérios de aceitação em um depósito final, estabelecidos pela CNEN (CNEN, 2002). A segurança operacional depende do atendimento aos requisitos regulatórios e normativos, técnicos ou administrativos, aplicáveis tanto nas fases de projeto e construção da unidade, como na de operação. Portanto, o programa de garantia da qualidade deve estabelecer um SGQ que opere desde a concepção da instalação e se estenda às fases operacional, de descomissionamento e encerramento.

Além da ausência de detalhes mais específicos no regulamento, a complexidade do SGQ da unidade de GRR pode requerer ferramentas gerenciais informatizadas, sendo que não foram encontrados comercialmente produtos já em sua forma final prontos para uso; existem programas para o Gerenciamento de Processos de Negócio (BPM - Business Process Management), como por exemplo o Bizagi (BIZAGI, 2018), TestRail (GUROCK, 2018) e o MasterControl (MASTERCONTROL, 2018), que requerem a introdução de um conjunto de dados específico da gestão de rejeitos para que possam ser utilizados no controle de garantia da qualidade de uma instalação de gestão de rejeitos radioativos. Uma análise deve ser realizada em cada situação quanto à opção mais indicada: desenvolver tal conjunto de dados de forma a adequar algum dos sistemas comerciais já existentes, ou desenvolver um sistema informatizado customizado. 
Em qualquer um dos casos, será igualmente necessário o mapeamento de processos da respectiva instalação. 


\section{OBJETIVOS}

O objetivo geral deste trabalho é o de reunir informações que permitam o desenvolvimento de bases para um sistema informatizado de garantia da qualidade específico para uma instalação de gestão de rejeitos radioativos, que esteja em conformidade com o regulamento da CNEN NN-1.16, e que possa englobar todos os procedimentos presentes neste tipo de unidade, em instituições como o IPEN, outros institutos da CNEN ou em um empreendimento como o Reator Multipropósito Brasileiro (RMB).

Para alcançar este objetivo geral, foram estabelecidos os seguintes objetivos específicos:

1) identificar os regulamentos, normas, especificações e documentos de boas práticas de engenharia aplicáveis;

2) efetuar correspondências entre a CNEN-NN-1.16 (CNEN, 2000) e outros regulamentos internacionais compatíveis;

3) identificar os procedimentos operacionais de cada processo a ser controlado, aqui chamadas operações elementares;

4) realizar um mapeamento de processos através do desenvolvimento de um conjunto de algoritmos lógicos, na forma de fluxogramas, com os procedimentos para aplicar os requisitos de garantia da qualidade do regulamento CNEN-NN-1.16 nas diversas atividades, itens, serviços e processos de uma instalação nuclear, de modo que possam posteriormente auxiliar como ferramenta no desenvolvimento de um sistema informatizado. 


\section{REVISÃO BIBLIOGRÁFICA}

Foram feitas diversas pesquisas em diferentes bases de dados (Web Of Science, ScienceDirect, Google Scholar, SciTech Connect, INIS, SciELO, CAPES) buscando artigos acadêmicos relativos à garantia da qualidade na gestão de rejeitos radioativos, porém o retorno foi exíguo; alguns dos documentos recuperados eram normas e regulamentos semelhantes aos do Brasil, sem acréscimo de informações relevantes.

Outros artigos encontrados descrevem os sistemas de garantia da qualidade utilizados em laboratórios locais, porém não tratam da operacionalização do referido sistema, não acrescentando, da mesma forma, qualquer informação que já não estivesse presente nos regulamentos brasileiro ou americano.

Além da busca por artigos acadêmicos, foram realizadas pesquisas nos seguintes campos:

\subsection{Leis Nacionais}

O estudo das leis brasileiras no âmbito federal permitiu a identificação das seguintes leis que fundamentam a regulamentação da área nuclear, mais especificamente a de gestão dos rejeitos radioativos.

Na Constituição da República Federativa do Brasil, de 1988, Artigo 21 inciso XXIII, estabelece-se que compete à União “...explorar os serviços e instalações nucleares de qualquer natureza e exercer monopólio estatal sobre a pesquisa, a lavra, o enriquecimento e reprocessamento, a industrialização e o comércio de minérios nucleares e seus derivados"; no Artigo 22 inciso XXVI, compete privativamente à União legislar sobre "atividades nucleares de qualquer natureza"; e no Artigo 177 inciso V estabelece-se que é monopólio da União a "pesquisa, a lavra, o enriquecimento, o reprocessamento, a industrialização e o comércio de minérios e minerais nucleares e seus derivados, com exceção dos radioisótopos cuja produção, comercialização e utilização poderão ser autorizadas sob regime de permissão..." (BRASIL, 1988).

A primeira lei brasileira que veio dispor sobre a política nacional de energia nuclear foi a Lei № 4.118 promulgada em 27 de agosto de 1962 (BRASIL, 1962), com a criação da CNEN. Após revisões, em 16 de dezembro de 1974, pela 
Lei № 6.189 (BRASIL, 1974) e, posteriormente, pela Lei no 7.781 de 27 de junho de 1989 (BRASIL, 1989), a CNEN tornou-se a responsável por regulamentar a área nuclear do Brasil em seus diversos âmbitos.

No ano de 2001, em 20 de novembro, foi promulgada a Lei o 10.308 para dispor especificamente sobre depósitos provisórios de rejeitos radioativos, tornando a CNEN responsável pelos procedimentos de projeto, construção e operação (BRASIL, 2001). No entanto, depósitos iniciais e o descomissionamento em geral não fazem parte das responsabilidades da CNEN, e sim dos operadores.

Em 19 de outubro de 2006, pelo Decreto № 5.935 (BRASIL, 2006), foi internalizada no ordenamento jurídico brasileiro a Convenção Conjunta para o Gerenciamento Seguro de Combustível Nuclear Usado e dos Rejeitos Radioativos. Tal convenção havia sido celebrada pela Agência Internacional de Energia Atômica (AIEA) e realizada na cidade de Viena, Áustria, de 1 a 5 de setembro de 1997, tendo sido assinada pelo Governo brasileiro em 31 de outubro do mesmo ano. A Convenção Conjunta é o primeiro instrumento legal que aborda a questão da segurança do gerenciamento do combustível nuclear usado e dos rejeitos radioativos em escala global (IAEA, 2017).

Assim sendo, segundo as leis brasileiras, a CNEN é a entidade responsável por regulamentar e controlar a área nuclear no Brasil, em suas diversas evoluções.

\subsection{Regulamentos da CNEN}

A CNEN estabeleceu regulamentos que foram divididos em nove grupos. A regulamentação relativa à garantia da qualidade a ser aplicada em uma instalação de gestão de rejeitos radioativos consta no primeiro grupo, "Normas para Instalações Nucleares", sendo esta a CNEN-NN-1.16 "Garantia da qualidade para a Segurança de Usinas Nucleoelétricas e outras Instalações" (CNEN, 2000).

Os outros regulamentos que devem ser aplicados em uma instalação deste tipo são os do grupo 6 "Instalações Radiativas" - CNEN-NE-6.06 "Seleção e Escolha de Locais para Depósitos de Rejeitos Radioativos" (CNEN, 1990), e CNEN-NE-6.09 "Critérios para Aceitação e Deposição de Rejeitos Radioativos de Baixo e Médio Níveis de Radiação" (CNEN, 2002); e do grupo 8 "Rejeitos Radioativos" - CNEN-NN-8.01 "Gerência de Rejeitos Radioativos de Baixo e 
Médio Níveis de Radiação" (CNEN, 2014), e CNEN-NN-8.02 "Licenciamento de Depósitos de Rejeitos Radioativos de Baixo e Médio Níveis de Radiação" (CNEN, 2014). No regulamento CNEN-NN-8.02, para a preparação do Relatório Final de Análise de Segurança (RFAS) de depósitos finais, o item 8 - anexo III do regulamento remete à CNEN-NN-1.16 como base para a descrição dos programas de garantia de qualidade para as fases de projeto, construção e operação de um depósito final (CNEN, 2014).

\subsection{Manuais da Agência Internacional de Energia Atômica}

A International Atomic Energy Agency (IAEA), ou Agência Internacional de Energia Atômica, é uma organização internacional estabelecida em 1957 de forma autônoma, porém relacionando-se com a Assembleia Geral e - Conselho de Segurança das Nações Unidas. Constitui um fórum intergovernamental para a cooperação científica e técnica do uso pacífico da tecnologia nuclear.

Um dos objetivos da Agência é fornecer recomendações e padrões na área nuclear, buscando sempre a segurança no uso pacífico da energia nuclear. Assim, foi elaborada ao longo dos anos uma extensa quantidade de material de suporte, na forma de manuais, relatórios técnicos e normas de segurança, relativos aos diversos campos no âmbito nuclear. Os documentos direta ou indiretamente referentes à gestão de rejeitos radioativos localizados são os seguintes:

- "Radioactive Waste Management Glossary" (Glossário de Gestão de Rejeitos Radioativos): Glossário de termos utilizados na área de gestão de rejeitos radioativos (IAEA, 2003).

- "Radioactive Waste Management Information Systems - Radioactive Waste Management Registry" (Inventário de Gestão de Rejeitos Radioativos): Compêndio de dados sobre pesquisas, inventários, instalações e práticas de gestão de rejeitos radioativos elaborado pela IAEA a seus Estados membros e partes interessadas, utilizando a tecnologia de internet atualizada (IAEA, 2015).

- "Application of Quality Assurance to Radioactive Waste Disposal Facilities" (Aplicação da Garantia da Qualidade em Instalações de Deposição de 
Rejeitos Radioativos): trata de princípios da garantia da qualidade para a disposição segura dos rejeitos radioativos (IAEA, 1996).

- "The Management System for Facilities and Activities - Safety Requirements" (Sistema de Gestão para Instalações e Atividades - Requisitos de Segurança): estabelece requisitos para sistemas de gestão que integram segurança, saúde, garantia da qualidade e objetivos ambientais. Auxilia no estabelecimento e implementação de sistemas de gestão eficazes que integrem todos os aspectos da gestão de instalações e atividades nucleares de forma coerente (IAEA, 2006).

- "Manual on Training, Qualification and Certification of Quality Assurance Personnel' (Manual de Formação, Qualificação e Certificação de Pessoal de Garantia da Qualidade): este manual aplica-se aos participantes em um projeto de instalação nuclear que estejam associados ao estabelecimento e implementação dos vários programas de garantia da qualidade (QA) durante o ciclo de vida do projeto. Ele fornece exemplos de funções de controle de qualidade típicas a serem realizadas e os requisitos de qualificação associados, programas e técnicas de treinamento, e métodos de certificação do pessoal que implementa essas funções (IAEA, 1986).

- "Regulatory Inspection of the Implementation of Quality Assurance Programmes: A Manual' (Inspeção de Regulamentação da Implementação de Programas de Garantia da Qualidade: um Manual): orienta na organização e desempenho das funções de inspeção regulatória sobre implementação de programas de garantia da qualidade em todas as etapas do projeto de uma instalação nuclear. O manual destina-se principalmente ao pessoal de gerenciamento e de órgãos reguladores, mas também é útil para o pessoal de gerenciamento de serviços e fornecedores nucleares (IAEA, 1989).

- "Implementation of Quality Assurance Corrective Actions: A Manual" (Implementação de Ações Corretivas da Garantia da Qualidade: um Manual): este manual foi desenvolvido para servir de guia sobre não conformidade e ações corretivas, identificadas como os principais problemas na implementação de um programa efetivo de garantia da qualidade. O escopo deste manual também abrange processos de ações corretivas que, em geral, ajudam os usuários no desenvolvimento de boas práticas para melhorar o desempenho em todas as áreas de segurança, confiabilidade e economia, e 
oferece um modelo prático e exemplos ilustrativos dos meios pelos quais ações e medidas efetivas podem ser implementadas (IAEA, 1990).

- "Grading of Quality Assurance Requirement: A Manual" (Classificação de Requisitos de Garantia da Qualidade: um Manual): a proposta deste manual é fornecer orientações e exemplos ilustrativos para aplicação de um método pelo qual os requisitos classificados de garantia da qualidade possam ser determinados e adaptados aos itens e serviços de uma usina de energia nuclear, assegurando que os itens e serviços significativos tenham medidas de controle e verificação mais rigorosas do que itens ou serviços de menor importância, e que estejam em conformidade com as especificações técnicas necessárias. Ainda que seja focado em uma usina de energia nuclear, o método apresentado neste manual trata dos aspectos de gestão, documentação, controle, verificação e administração que afetam a qualidade (IAEA, 1991).

- “Quality Assurance Integrated Training Packages: A Manual" (Pacotes de Treinamento Integrados de Garantia da Qualidade: um Manual): apresenta pacotes de treinamento que abrangem princípios e práticas de garantia da qualidade, que podem ser modificados para atender a diferentes níveis de gerenciamento, bem como ser adaptados às situações locais e às diferentes necessidades no campo da garantia da qualidade (IAEA, 1992).

- "The IAEA Online Information Resource for Radioactive Waste Management" (Fonte de informações on-line da AIEA para a gestão de rejeitos radioativos): contém informações sobre programas nacionais de gestão, inventários e depósitos de rejeitos radioativos, leis e regulamentos relevantes, políticas de gestão de rejeitos, planos e atividades. Atualizado anualmente (IAEA, 2002).

\subsection{Regulamentações em Outros Países}

A pesquisa foi continuada buscando-se informações sobre a regulamentação em outros países com atividades na área nuclear.

Na Europa, a Agência de Energia Nuclear (AEN) da Organização para a Cooperação e o Desenvolvimento Econômico (OCDE) foi criada em Paris em 1958 e adquiriu seu nome atual em 1972, quando o Japão se tornou seu primeiro membro fora da Europa. Atua em estreita colaboração com a Agência Internacional de Energia Atômica, em Viena. As áreas de especialização da AEN 
incluem segurança nuclear, licenciamento, gestão de rejeitos radioativos, e políticas de energia nuclear. Possui autoridades reguladoras para o controle da gestão de rejeitos radioativos dos países-membros (OCDE, 2004).

$\mathrm{Na}$ França, o Ministério responsável por pesquisa, energia e meio ambiente estabeleceu há mais de 30 anos a empresa ANDRA como a responsável pela gestão de longo prazo de todos os rejeitos radioativos produzidos no país. O repositório definitivo francês é o Centre de l'Aube, de superfície. O programa de garantia da qualidade desenvolvido para a instalação é baseado em três níveis de verificação, envolvendo inspeção, rastreamento e ensaios destrutivos e não-destrutivos de rejeitos. Estas verificações garantem a conformidade com as especificações técnicas estipuladas pela ANDRA (ERRERA; TISON, 2001; OUZOUNIAN, 2016).

A segurança para operação de instalações nucleares na Grã-Bretanha, incluindo aquelas para tratamento e armazenamento de rejeitos radioativos, é regulada pela Health and Safety Executive - HSE (Diretoria de Saúde e Segurança), de acordo com a Lei de Instalações Nucleares, de 1965. O titular da licença da instalação fica responsável pelo gerenciamento seguro dos rejeitos radioativos (OCDE, 2004). O regulamento utilizado para elaboração do programa de garantia da qualidade na área nuclear busca, tal qual realizado no Brasil, estabelecer compatibilidade com os princípios de garantia da qualidade dispostos na regulamentação americana 10 CFR 50 - anexo B e os códigos de prática 50C-QA da Agência Internacional de Energia Atômica (BSI, 1996).

$\mathrm{Na}$ Espanha, a empresa pública responsável pelo gerenciamento e armazenamento seguro de rejeitos radioativos é a ENRESA. Seus programas de garantia da qualidade, em especial o do depósito de El Cabril, seguem o mesmo formato do regulamento americano ASME-NQA-1-2008 (EOI, 2011).

A entidade responsável, entre outras áreas, pela construção e operação de depósitos e repositórios de armazenamento de rejeitos radioativos na Alemanha é o Bundesamt für Strahlenschutz - BfS (Escritório Federal de Proteção Radiológica), submetido ao Bundesministerium für Umwelt, Naturschutz und nukleare Sicherheit - MBU (Ministério do Meio Ambiente, Conservação da Natureza e Segurança de Reatores). Os custos de construção e operação dos depósitos de rejeitos radioativos são pagos pelos produtores dos rejeitos radioativos, em geral, serviços públicos (OCDE, 2004). Também possui um 
Departamento de Auto-Vigilância, que é uma unidade organizacional independente do Escritório Federal, responsável por verificar quaisquer mudanças, não conformidades e ações corretivas que venham a afetar a licença outorgada à instalação radiativa (BECKMERHAGEN; BERG; HARNACK, 1996).

R.O. Abdel Rahman, A.M. El-Kamash, F.A. Shehata, e El-Sourougy, M.R. (2007) descreveram o sistema de gestão de rejeitos radioativos sólidos no Egito, descrevendo alguns métodos de tratamento e armazenamento, e a estrutura organizacional utilizada em laboratório no Cairo. Também descreveu o programa de garantia de qualidade instituído, porém sem detalhes quanto à sua operacionalização. Um manual de garantia de qualidade foi desenvolvido para este mesmo laboratório no Cairo (MOHAMED, 2007), baseando-se nas normas da AIEA, e nos regulamentos americanos do NRC e do DOE/RW-0333P, no entanto de forma simplificada.

\subsection{Regulamentação nos Estados Unidos da América}

Verificou-se uma maior compatibilidade entre as estruturas das leis americanas e das leis brasileiras aplicadas à área nuclear. Os padrões americanos mais recentes de garantia da qualidade na área nuclear foram desenvolvidos pela Sociedade Americana de Engenheiros Mecânicos (American Society of Mechanical Engineers - ASME) a partir de 1975, por solicitação do Instituto Americano Federal de Padrões (American National Standards Institute ANSI) refletindo a estrutura da 10 CFR 50, Apêndice B (U.S.DOE, 2011), que consiste em 18 itens, conforme disposto abaixo:

1. Organização

2. Programa de Garantia da qualidade

3. Controle de Projeto

4. Controle de Documentos de Aquisição

5. Instruções, Procedimentos e desenhos

6. Controle de Documentos

7. Controle de Compra de Materiais, Equipamentos e Serviços

8. Identificação e Controle de Materiais, Partes e Componentes

9. Controle de Processos Especiais

10. Inspeção 
11. Controle de Testes

12. Controle de Equipamentos de Medição e Testes

13. Manipulação, Armazenamento e Transporte

14. Situações de Inspeção, Teste e Operação

15. Materiais, Partes ou Componentes Não Conformes

16. Ações Corretivas

17. Registros de Garantia da qualidade

18. Auditorias

Teve sua primeira edição publicada em 1979, e desde então esta regulamentação foi por diversas vezes atualizada e expandida, conforme 0 desenvolvimento da área. A edição atual é o ASME-NQA-1-2017 (ASME, 2017).

No empreendimento nuclear americano, as entidades governamentais e comerciais, devido a suas próprias adequações, seguem diferentes edições do NQA-1. Desde 1985, a Comissão Reguladora Nuclear (Nuclear Regulatory Commission - NRC) aprovou partes do NQA-1-1983 em seus guias regulatórios. Além das inclusões em guias regulatórios, as aprovações da NRC foram determinadas em função da aceitação de solicitações de licenciamento de empresas que se propuseram a utilizar a NQA-1 como guia de implementação do 10 CFR 50, Apêndice B (U.S.DOE, 2011).

O fato de que as instalações comerciais (por exemplo, usinas de energia) e as instalações nucleares do Departamento de Energia (Department of Energy - DOE) estão sujeitas a regulamentos e autoridades diferentes termina por incentivar a diversificação de edições da norma. A NRC regula as instalações comerciais, enquanto que o DOE regula as suas próprias instalações. Ao contrário das instalações comerciais sujeitas à 10 CFR 50 , as instalações do DOE seguem a 10 CFR 830 ("Gestão de Segurança Nuclear") Subparte A- "Requisitos da Garantia da qualidade". O DOE, por regra, exige a utilização de padrões nacionais e internacionais adequados para a implementação de seus requisitos de garantia da qualidade (U.S. FEDERAL REGISTER, 2001).

Em seu programa de garantia da qualidade do repositório de Yucca Mountain, no estado de Nevada, o Escritório de Gestão de Rejeitos Radioativos Comerciais (OCRWM, 2009) do DOE desenvolveu um documento tendo por base os mesmos 18 itens do ASME-NQA-1, sendo este o DOE/OCWRM-QARD 
"Quality Assurance Requirements and Description" (Requisitos e Descrição da Garantia da Qualidade), atualmente em sua vigésima primeira versão.

Ainda que o documento acima tenha sido elaborado especificamente para a garantia da qualidade na gestão de rejeitos radioativos de alto nível, os requisitos de controle são os mesmos que os utilizados em uma instalação de gestão de rejeitos de baixo e médio níveis de radiação, bem como os constantes na CNEN-NN-1.16. Assim sendo, decidiu-se estudar o DOE/OCRWM-QARD v.21, buscando as analogias com o documento brasileiro CNEN-1.16, e apresentar o detalhamento dos requisitos americanos que possam ser utilizados visando o aprimoramento do programa de garantia da qualidade de uma instalação de gestão de rejeitos radioativos no Brasil. 


\section{MÉTODOS}

As leis nacionais foram estudadas para melhor compreensão do âmbito legal no Brasil. A seguir, foram estudados os regulamentos da CNEN, sendo identificados os correspondentes à área de gestão de rejeitos radioativos. Uma série de recomendações da AIEA relativas à mesma área também foram estudadas, para conhecimento das melhores práticas.

Conforme já citado anteriormente na revisão bibliográfica, buscaram-se artigos acadêmicos sobre garantia da qualidade na gestão de rejeitos radioativos nas diversas bases de dados, porém foram poucos os encontrados, o que evidencia a necessidade de publicações futuras com análises mais aprofundadas sobre o tema.

Posteriormente, foi feito um estudo sobre a regulamentação da área nuclear em outros países. e verificou-se que nos Estados Unidos da América alguns dos principais regulamentos daquele país possuem a mesma estrutura que o regulamento da CNEN NN-1.16. Conforme já descrito no item Revisão Bibliográfica deste trabalho, ao aprofundar estas pesquisas, encontrou-se um documento do Departamento de Energia dos Estados Unidos preparado especificamente para a garantia da qualidade na gestão de rejeitos radioativos do repositório de Yucca Mountain, o DOE/RW/0333P (OCRWM, 2009). Este foi o regulamento encontrado mais compatível com o CNEN-NN-1.16.

Assim, foram realizadas a análise e a correlação da norma americana DOE/RW-0333P com a CNEN-NN-1.16, com identificação de seus pontos em comum. Os procedimentos mais específicos foram relacionados.

\section{Mapeamento de processos via fluxogramas}

De acordo com o estatístico americano William Edwards Deming, considerado o pai da evolução na qualidade, "se você não é capaz de descrever o que você faz como um processo, então você não sabe o que está fazendo" (PMQM, 2018). Dando continuidade a este raciocínio, para que o mapeamento obtenha êxito, o processo precisará ser executável por uma pessoa que trabalhe na área do processo em questão e compreensível para uma pessoa da instalação que não trabalhe na área. 
Mapeamento é a descrição do processo em uma linguagem. Em seu livro "BPMN Method and Style" (SILVER, 2009), Bruce Silver define o mapeamento em três tipos: 1) Descritivo: procura basicamente alinhar o entendimento a respeito do funcionamento geral do processo. 2) Analítico: além de mostrar os passos, inclui as exceções e tratamentos de erros, necessários tanto para melhorar a performance de um processo de trabalho quanto para subsidiar o desenho de um sistema informatizado pela equipe de TI. 3) Executável: a modelagem nesse nível criaria o sistema informatizado diretamente a partir do desenho do processo de trabalho. Seria o objetivo máximo dos profissionais de TI e de Gestão de Processos.

Entre os benefícios do mapeamento, este proporciona melhor conhecimento e entendimento sobre o processo, permite uma visualização mais clara da sequência das atividades, facilita a análise e melhoria do processo (sua modelagem), bem como a sua informatização, e melhora os fluxos de informação e comunicação (DAMELIO, 2011).

O mapeamento de processos mais utilizado atualmente é o fluxograma, devido a sua facilidade de elaboração e entendimento. O fluxograma é uma representação gráfica formalizada de uma sequência lógica programada, trabalho, processo de manufatura, ou estrutura em geral (AGUILAR-SAVÉN, 2004).

Para efetuar 0 mapeamento de processos dos requisitos da regulamentação CNEN-NN-1.16 (CNEN, 2000), foram feitas a identificação e o detalhamento de cada um dos processos a serem controlados pelo sistema, estabelecendo os dados de entrada, as operações elementares de cada processo, os dados de saída, os pontos de controle do processo, os requisitos de bancos de dados, entre outros componentes do sistema.

Algoritmos foram elaborados com base nesses dados, descrevendo as operações elementares a serem executadas. As operações incluídas no escopo de trabalho são aquelas necessárias para controle e registro administrativo das ações de Garantia da Qualidade, de forma a demonstrar que as exigências regulatórias da CNEN-NN-1.16 foram cumpridas. As operações elementares podem ser entendidas como procedimentos mais básicos a serem seguidos para a operacionalização do SGQ. A cada lista de operações elementares foi associado um fluxograma lógico que representa visualmente os processos, as 
ações ou eventos que iniciam os processos, as entradas e saídas de dados, os pontos de controle, e bancos de dados requeridos pelo sistema.

Foram feitos fluxogramas para cada um dos itens a serem controlados na CNEN-NN-1.16, na visão de um sistema informatizado, com processos para inclusão de dados, edição e revisão de executores, verificadores e gerentes, conforme disposto neste regulamento. 


\section{RESULTADOS}

Após análise das correspondências entre os itens da DOE/RW-0333P v.21 (OCRWM, 2009) e os da CNEN-NN-1.16 (CNEN, 2000) verificou-se que, ainda que os dois regulamentos tenham sido baseados nos 18 requisitos anteriormente citados da 10 CFR 50, Apêndice B (U.S.DOE, 2011), alguns dos requisitos foram combinados, reduzindo assim o seu número.

O regulamento americano, por outro lado, possui um número maior de subitens em cada requisito, e tais subitens em muitos casos estão associados a outros requisitos que não os seus próprios. Assim, foram elaboradas a Tabela 01, com as correlações encontradas entre os subitens do documento brasileiro e 0 americano, e a Tabela 02, com as correlações entre os subitens do documento americano e o brasileiro.

Tabela 01 - Correlação entre os itens CNEN 1.16 e os da DOE/RW-0333P v.21

\begin{tabular}{ll}
\multicolumn{1}{c}{ CNEN-NN-1.16 } & \multicolumn{1}{c}{ OCRWM QARD } \\
\hline 4.1 Sistemas de Garantia da Qualidade & 1.0 \\
4.1.1 Obrigatoriedade e Responsabilidades & $1.2 ; 1.2 .1 ; 1.3 .1-2$ \\
4.1.2 Diretrizes Básicas & $1.3 .1 ; 2.2 .2-4 ; 2.2 .7 ;$ \\
& 2.2 .12 \\
4.1.3 Idioma & - \\
4.1.4 Procedimentos, Instruções e Desenhos & $5.0 ; 5.2 .1-2$ \\
4.1.5 A Avaliação pela Gerência & $2.2 .6 ; 2.2 .10$ \\
\hline 4.2 Programas de Garantia da qualidade & $2.0 ; 2.2 .1 ; 2.2 .4 ; 2.2 .8$ \\
\hline 4.3 Organização & 1.0 \\
4.3.1 Responsabilidades, Autoridades e Comunicações & $1.1-2 ; 1.2 .1 ; 1.3 .1-2$ \\
4.3.2 Interfaces Organizacionais & 1.3 .3 \\
4.3.3 Seleção e Treinamento de Pessoal & 2.2 .11 \\
\hline 4.4 Controle de Documentos & 6.0 \\
4.4.1 Preparação, Análise e Aprovação de Documentos & $6.2 .1-3 ; 6.2 .4$ \\
4.4.2 Liberação e Distribuição de Documentos & 6.2 .5 \\
4.4.3 Controle de Alterações em Documentos & 6.2 .6 \\
\hline 4.5 Controle de Projeto & 3.0 \\
4.5.1 Requisitos Gerais & $2.2 .4 ; 3.2 .1-2 ; 3.2 .6-7$ \\
4.5.2 Interfaces de Projeto & 3.2 .7 \\
4.5.3 Verificação de Projeto & $3.2 .4-5$ \\
4.5.4 Alterações de Projeto & 3.2 .6 \\
\hline 4.6 Controle de Aquisições & $4.0 ; 7.0$ \\
4.6.1 Requisitos Gerais & $7.1 ; 7.2 .1 ; 7.2 .5$ \\
4.6.2 Avaliação e Seleção de Fornecedores & $3.2 .8 ; 7.2 .2-4$ \\
4.6.3 Controle de Itens e Serviços Adquiridos & $7.2 .6-9$ \\
\hline 4.7 Controle de Materiais & - \\
4.7.1 Identificação e Controle de Materiais, Peças e Componentes & $8.0-1 ; 8.2 .1-3$ \\
4.7.2 Manuseio, Armazenagem e Embarque & $13.0 ; 13.2 .1-2$ \\
\hline 4.8 Controle de Processos & $9.0-1 ; 9.2 .1-2$ \\
\hline 4.9 Controle de Inspeção e Testes & - \\
4.9.1 Programa de Inspeção & $2.2 .5 ; 3.2 .8 ; 10.0 ; 10.1 ;$ \\
& $10.2 .2-5$ \\
\hline &
\end{tabular}




\begin{tabular}{ll}
\hline 4.9.2 Programa de Testes & $11.0-1 ; 11.2 .1 ; 11.2 .4-5$ \\
4.9.3 Calibração e Controle de Equipamentos de Teste e de & $12.0 ; 12.2 .1 ; 12.2 .3 ;$ \\
Medição & 12.2 .5 \\
4.9.4 Situações das Inspeções, Testes e Estado Operacional de & $14.0 ; 14.2 .1-2$ \\
$\quad$ Itens & 15.0 \\
\hline 4.10 Controle de Itens Não Conformes & $15.2 .1-2$ \\
4.10.1 Requisitos Gerais & $15.2 .1 ; 15.2 .3-4$ \\
4.10.2 Avaliação e Destinação de Itens Não Conformes & $16.0 ; 16.2 .2 ; 16.2 .4 ;$ \\
\hline 4.11 Ações Corretivas & 16.2 .6 \\
\hline 4.12 Registros de Garantia da Qualidade & 17.0 \\
4.12.1 Preparação dos Registros & $17.2 .1 ; 17.2 .2$ \\
4.12.2 Coleta, Arquivo e Preservação dos Registros & $17.1 ; 17.2 .3-4 ; 17.2 .6 ;$ \\
& $17.2 .8-9 ; 17.2 .12$ \\
\hline 4.13 Auditorias & 18.0 \\
4.13.1 Requisitos Gerais & $18.2 .5-8 ; 18.2 .10-13$ \\
4.13.2 Programação & $18.2 .1-3$ \\
\hline
\end{tabular}

Fonte: autor da dissertação.

Tabela 02 - Correlação entre os itens DOE/RW-0333P v.21 e os da CNEN 1.16

\begin{tabular}{ll}
\hline OCRWM QARD & CNEN-NN-1.16 \\
\hline 1.0 Organization & $4.1 ; 4.3$ \\
1.1 General & $4.3 .1 .1-2$ \\
1.2 Requirements & $4.1 .1 .1 ; 4.3 .1 .3$ \\
1.2.1 Responsibility for Quality & $4.1 .1 .3 ; 4.3 .1 .2$ \\
1.2.2 Resolution of Quality Disputes & - \\
1.3 Description & - \\
1.3.1 OCRWM Organization Descriptions & $4.1 .1 .4 ; 4.1 .2 ; 4.3 .1 .4$ \\
1.3.2 Delegation of Authority & $4.1 .1 .2 ; 4.3 .1 .5$ \\
1.3.3 Principal Contractors & 4.3 .2 .1 \\
1.3.4 Waste Custodians (Spent Nuclear Fuel \& H-Level Waste Form & \\
Prods.) & - \\
1.3.5 Commitment Document Positions & - \\
\hline 2.0 Quality assurance program & 4.2 \\
2.1 General & - \\
2.2 Requirements & - \\
2.2.1 Quality Assurance Program Documents & $4.2 .1-2-3-4$ \\
2.2.2 Quality Assurance Program Applicability and Related Activities & 4.1 .2 \\
2.2.3 Classifying Structures, Systems, and Components & 4.1 .2 .5 \\
2.2.4 Planning Work & $4.1 .2 ; 4.2 .1 ; 4.5 .1$ \\
2.2.5 Surveillances & $4.9 .1 .1-2$ \\
2.2.6 Management Assessments & 4.1 .5 .1 \\
2.2.7 Readiness Reviews & 4.1 .2 .10 \\
2.2.8 Peer Reviews & 4.2 .1 .5 \\
2.2.9 Expert Elicitation & - \\
2.2.10 Quality Assurance Program Self Assessments & 4.1 .5 .1 \\
2.2.11 Personnel Indoctrination, Training, Qualification, and Certification & 4.3 .3 \\
2.2.12 Scheduled Frequency Tolerance & 4.1 .2 .1 \\
2.2.13 Commitment Document Positions & - \\
\hline 3.0 Design control & 4.5 \\
3.1 General & - \\
3.2 Requirements & - \\
3.2.1 Design Input Control & 4.5 .1 .1 \\
3.2.2 Design Process & $4.5 .1 .2-3-4-5$ \\
3.2.3 Design Analyses & - \\
\hline &
\end{tabular}




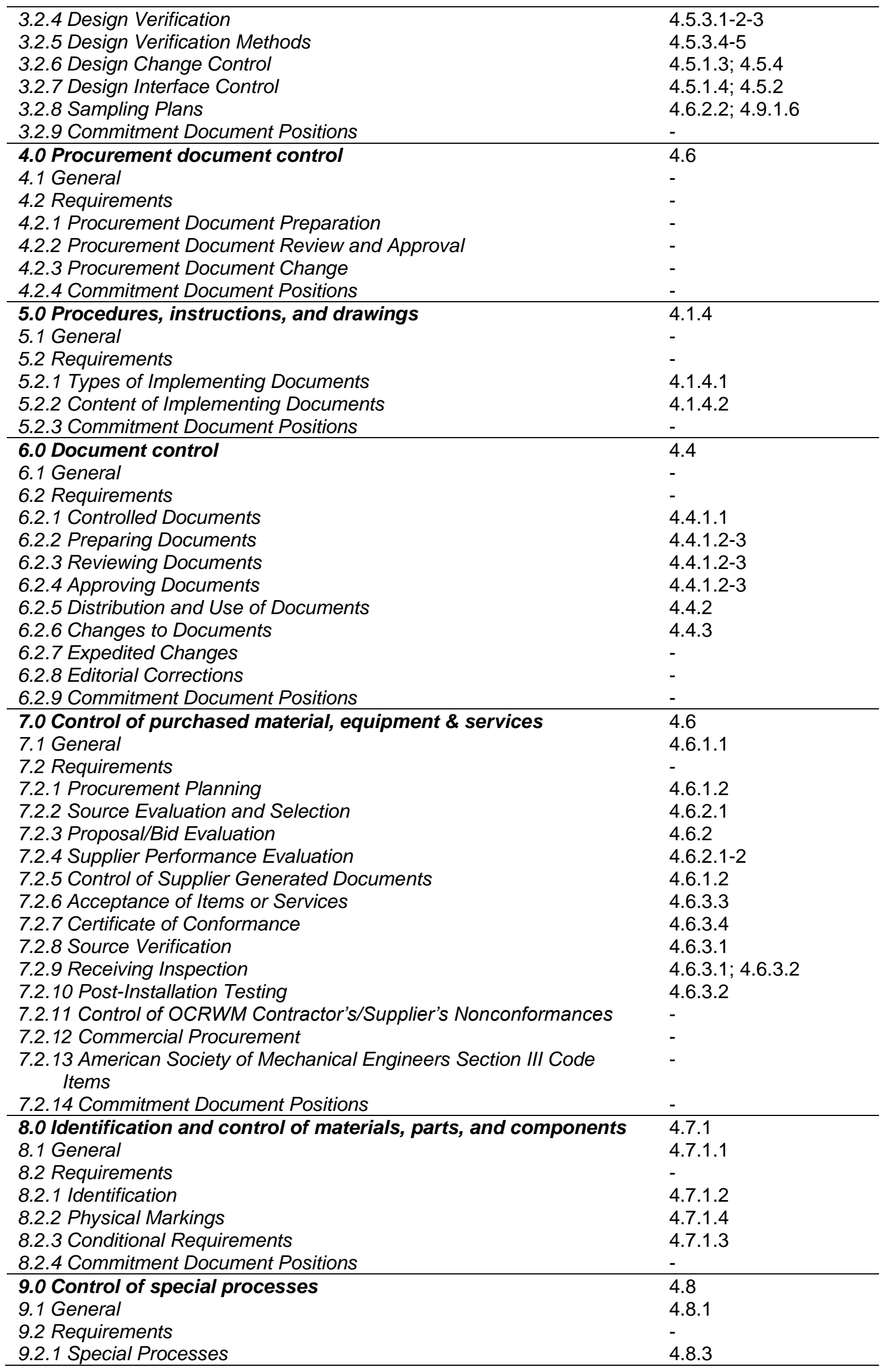




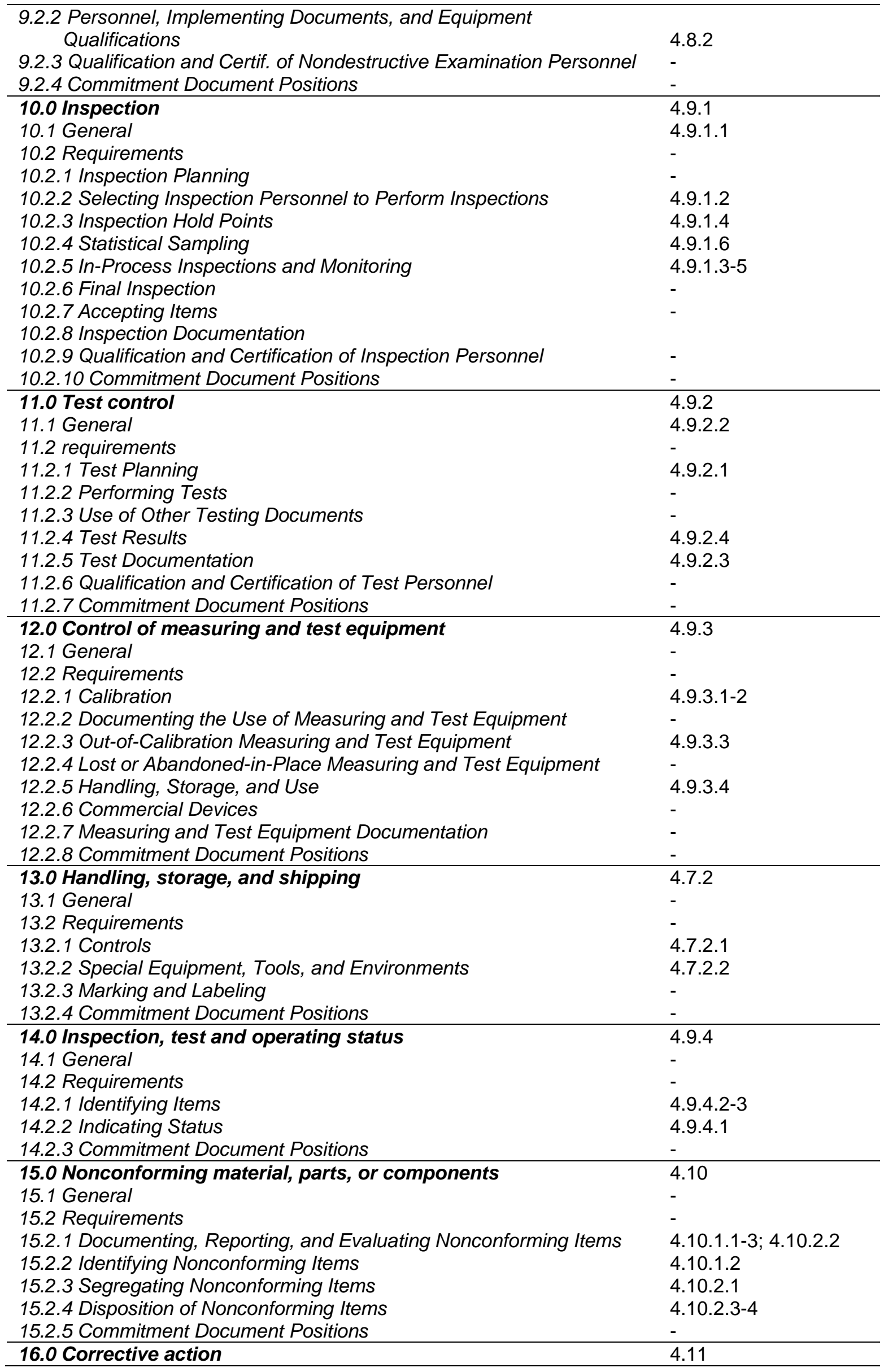




\begin{tabular}{ll}
\hline 16.1 General & - \\
16.2 Requirements & - \\
16.2.1 Identifying Conditions Adverse to Quality & - \\
16.2.2 Classification of Conditions Adverse to Quality & 4.11 .1 \\
16.2.3 Conditions Adverse to Quality & - \\
16.2.4 Significant Conditions Adverse to Quality & 4.11 .3 \\
16.2.5 Follow-up & - \\
16.2.6 Quality Trending & 4.11 .2 \\
16.2.7 Commitment Document Positions & - \\
\hline 17.0 Quality assurance records & 4.12 \\
17.1 General & 4.12 .2 .1 \\
17.2 Requirements & - \\
17.2.1 Quality Assurance Records & 4.12 .1 .2 \\
17.2.2 Creating Valid Quality Assurance Records & 4.12 .1 .3 \\
17.2.3 Submission of Quality Assurance Records & 4.12 .2 .1 \\
17.2.4 Receiving and Indexing Quality Assurance Records & 4.12 .2 .2 \\
17.2.5 Correcting Information in Quality Assurance Records & - \\
17.2.6 Storing and Preserving Quality Assurance Records & 4.12 .2 .2 \\
17.2.7 Retrieval of Quality Assurance Records & - \\
17.2.8 Retention of Quality Assurance Records & $4.12 .2 .3-6$ \\
17.2.9 Turnover of Quality Assurance Records & 4.12 .2 .4 \\
17.2.10 Long-Term Single Storage Facility & - \\
17.2.11 Dual Storage Facilities & - \\
17.2.12 Temporary Storage Facility & 4.12 .2 .5 \\
17.2.13 Replacement of Quality Assurance Records & - \\
17.2.14 Commitment Document Positions & - \\
\hline 18.0 Audits & 4.13 \\
18.1 General & - \\
18.2 Requirements & - \\
18.2.1 Audit Scheduling & 4.13 .2 .1 \\
18.2.2 Scheduling Internal Audits & 4.13 .2 .2 \\
18.2.3 Scheduling External Audits & 4.13 .2 .2 \\
18.2.4 Audit Schedule & - \\
18.2.5 Audit Planning & 4.13 .1 .1 \\
18.2.6 Audit Team Independence & 4.13 .1 .3 \\
18.2.7 Audit Team Selection & 4.13 .1 .4 \\
18.2.8 Performing Audits & 4.13 .1 .2 \\
18.2.9 Reporting Audit Results & - \\
18.2.10 Responding to Audits & 4.13 .1 .6 \\
18.2.11 Evaluating Audit Finding Responses & 4.13 .1 .5 \\
18.2.12 Follow-up Action & 4.13 .1 .7 \\
18.2.13 Audit Team Qualification and Certification & 4.13 .1 .3 \\
18.2.14 Commitment Document Positions & - \\
\hline Eonte auto & \\
& \\
&
\end{tabular}

Fonte: autor da dissertação.

$\mathrm{Na}$ sequência, cada um dos requisitos de controle de garantia da qualidade da CNEN-NN-1.16 será apresentado, seguido de adaptação dos textos da DOE/RW-0333P que correspondam ao requisito.

Após os requisitos, seguem as listas de instruções com respectivos fluxogramas que descrevem as etapas necessárias para o controle da garantia da qualidade do requisito, visando sempre a conformidade com a CNEN-NN-1.16.

As sequências de operações elementares foram organizadas na forma de páginas, para melhor visualização como em um programa de computador. As 
diferentes páginas foram desenvolvidas visando assegurar que 0 SGQ proporcione a integração entre executores, verificadores e gerentes (aprovadores), conforme disposto no item 4.1.2.3 da CNEN-NN-1.16.

\subsection{Controle de Documentos}

Os requisitos da CNEN-NN-1.16 para tal estão especificados na seção 4.4 "Controle de Documentos". Esta seção está subdividida em três subseções referentes à preparação, distribuição e controle de alterações. A seguir, a primeira subseção 4.4.1 "Preparação, Análise e Aprovação de Documentos":

4.4.1.1 Os documentos essenciais à execução e verificação de atividades que influem na qualidade, tais como procedimentos, instruções, desenhos, ou outro tipo de mídia, devem ser controlados.

4.4.1.2 As medidas de controle dos documentos referidos na subseção anterior devem incluir:

a) a preparação, análise, aprovação, e emissão dos documentos; e

b) a identificação de todas as pessoas ou organizações responsáveis pelas tarefas especificadas na alínea a).

4.4.1.3 A organização ou pessoas responsáveis pela análise, e aprovação dos documentos referidos em 4.4.1.1 devem ter acesso às informações necessárias nas quais possam basear sua análise, e aprovação (CNEN, 2000).

O detalhamento realizado utilizando os itens correspondentes da regulação americana estão abaixo:

\section{- Documentos Controlados}

Os documentos controlados incluem documentos que especificam os requisitos de qualidade ou técnicos, ou definem atividades a serem monitoradas pela CNEN (ex.: documentos de projeto, documentos de aquisição, procedimentos, instruções e desenhos; documentos de descrição dos programas de garantia da qualidade, e relatórios de análise de segurança para distribuição e uso, com suas respectivas alterações). 
- Preparação de Documentos

A responsabilidade pela preparação de documentos deve ser atribuída à devida organização ou liderança.

\section{- Análise / Revisão de Documentos}

As normas que especificam os requisitos técnicos ou de garantia da qualidade, ou estabelecem atividades que são monitoradas pela CNEN, e suas respectivas alterações, devem ser revistas antes da aprovação e emissão quanto a correção, adequação, integridade, precisão e conformidade com os requisitos estabelecidos.

Quando especificado nos procedimentos de controle, a revisão deve ser realizada por outras pessoas, que não o autor, devidamente treinadas e qualificadas nas práticas e conceitos de controle de qualidade.

O departamento responsável pela garantia da qualidade deve rever os principais procedimentos de contratos que apresentem o desenvolvimento e a manutenção de seus procedimentos que afetam a qualidade. A revisão deve ser realizada e a aceitação documentada antes do início da atividade regida pelo procedimento.

Os comentários resultantes de revisões devem ser documentados e resolvidos a contento da organização responsável pelo documento antes da aprovação do mesmo.

- Aprovação de Documentos

A organização responsável pela aprovação do documento a ser liberado deve ser identificada.

Em seguida, a segunda subseção 4.4.2 "Liberação e Distribuição de Documentos":

4.4.2.1 Deve ser estabelecido um controle de liberação e distribuição de documentos, utilizando listas de distribuição atualizadas.

4.4.2.2 Devem ser estabelecidas medidas para assegurar que as pessoas participantes de uma atividade conheçam e usem os documentos corretos e apropriados para a realização da mesma. 
4.4.2.3 Devem ser adequadamente identificados os documentos obsoletos retidos. (CNEN, 2000).

O detalhamento realizado utilizando os itens correspondentes da regulação americana estão abaixo:

\section{- Liberação / Distribuição e Utilização de Documentos}

Devem ser estabelecidos métodos para identificar o estado atual de cada documento que deva ser controlado de acordo com esta seção. Este método deve estar acessível aos usuários dos documentos.

A disposição de documentos cancelados ou substituídos deve ser controlada para garantir que eles não venham mais a ser usados durante algum trabalho. Datas coerentes devem ser estabelecidas para a aplicação das normas aprovadas.

A versão mais atualizada (revisão ou alteração) de documentos, seja em mídia impressa ou eletrônica, deve estar disponível para acesso antes do início dos trabalhos no local onde a atividade será realizada. Estes documentos devem ser respeitados na realização do trabalho.

Por último, a terceira subseção 4.4.3 "Controle de Alterações em Documentos":

(4.4.3.1) As alterações em documentos devem estar sujeitas à análise e aprovação, de acordo com procedimentos documentados.

(4.4.3.2) As organizações responsáveis pela análise de alterações em documentos devem ter acesso às informações necessárias nas quais possam basear sua análise e aprovação, bem como um conhecimento adequado das exigências e intenções dos documentos originais.

(4.4.3.3) As alterações em documentos devem ser analisadas e aprovadas pela mesma organização ou pessoas que realizaram a análise e aprovação dos documentos originais, ou por outras organizações que sejam especificamente designadas para esse fim.

(4.4.3.4) Informações sobre alterações de documento e seu estado atual de revisão devem ser prontamente comunicadas a todas as pessoas e organizações afetadas pela revisão, para impedir o uso de documentos desatualizados e inadequados. 
(4.4.3.5) As alterações devem ser identificadas no documento ou em anexos apropriados. (CNEN, 2000).

O detalhamento realizado utilizando os itens correspondentes da regulação americana segue abaixo:

\section{- Alterações em Documentos}

As normas devem definir o método utilizado para a aplicação das mudanças. Caso o método definido seja diferente do anteriormente proposto no documento controlado revisado, deverá constar no documento o número máximo de alterações permitidas antes que seja solicitada a substituição do documento controlado revisado.

As normas devem exigir que um histórico de alterações em documentos do programa de controle de qualidade, incluindo as razões para tais alterações, seja realizado e conservado. Esse histórico de documentos deve ser revisto cada vez que forem propostas novas alterações no documento.

Alterações nos documentos, exceto correções editoriais, devem ser analisadas e aprovadas pelas mesmas organizações que realizaram a revisão e aprovação originais (caso estas organizações sejam afetadas pela modificação), a menos que a CNEN nomeie outra organização para tal. As organizações responsáveis pela revisão devem ter acesso aos dados de base pertinentes ou informações nas quais foram baseadas as aprovações.

\section{- Alterações Urgentes}

Caso uma atividade não possa ser realizada conforme estabelecido em um documento e o processo de mudança sofra atrasos indevidos, uma alteração urgente pode ser realizada no local de trabalho, pelo gerente responsável.

Após a alteração urgente ser autorizada, esta deve ser processada usando o procedimento padrão de alterações. Tal procedimento deve ocorrer em tempo hábil, de acordo com o tipo e a natureza do documento que esteja sendo alterado.

O processo de controle de mudanças urgentes deve ser documentado de acordo com os seguintes requisitos: 1) o nível de gerência com autoridade para fazer mudanças urgentes deve ser identificado; 2) os prazos limites para 
processamento de alterações urgentes usando o processo de alteração padrão devem ser especificados e 3) uma avaliação da atividade deve ser realizada caso o processo padrão de revisão resulte em uma alteração que seja diferente da alteração urgente.

\section{- Correções Editoriais}

Correções editoriais que não têm impacto significativo quanto à exigência de documentos podem ser realizadas sem estarem sujeitas aos requisitos de revisão, porém tais correções devem ser distribuídas na forma de revisão ou alteração do documento.

Os seguintes itens são considerados correções editoriais:

- Correção gramatical ou ortográfica.

- Renumeração de seções ou anexos que não afete a sequência cronológica do trabalho.

- Alteração de títulos ou números de documentos mencionados no procedimento.

- Atualização de nomes de organizações.

Uma alteração em um nome de organização acompanhada de uma mudança de responsabilidades não é considerada uma correção editorial.

A organização responsável pela aprovação do documento para liberação do mesmo deve aprovar as correções editoriais.

As páginas a seguir são a de "Inclusão de Documentos" e a de "Consulta de Edição de Documentos", utilizadas pelo executor; "Verificação de Documentos", utilizada pelo verificador; e "Aprovação de Documentos", a ser utilizada pelo gerente.

\subsubsection{Página Inclusão de Documentos}

Itens a serem apresentados na página "Inclusão de Documentos":

- Título "Inclusão de Documentos";

- Nome do usuário e data / horário de acesso;

- Caixa de entrada com o texto "Documento referente a qual departamento / item / processo?"; 
- Caixa de entrada com o texto "Qual a procedência do documento?";

- Caixa de entrada com o texto "Qual a finalidade do documento?";

- Caixa de entrada com o texto "Registro de localização do documento";

- Caixa de entrada com o texto "Caso necessária, qual a validade do documento?";

- Caixa de entrada com o texto "A quem encaminhar o documento?";

- Botão "Salvar";

- Botão "Limpar campos";

- Botão "Sair".

Operações elementares:

1) Digitar "Documento referente a qual departamento / item / processo?" (ou selecionar dentre os departamentos / itens / processos já incluídos no banco de dados);

2) Digitar "Qual a procedência do documento?";

3) Digitar "Qual a finalidade do documento?";

4) Digitar "Registro de localização do documento";

5) Se for o caso, digitar "Caso necessária, qual a validade do documento?";

6) Se for o caso, digitar "Caso necessário, a quem encaminhar o documento?";

7) Clicar em "Salvar". O sistema verifica se os itens 1) a 4) foram digitados. Caso negativo, apresenta mensagem "Obrigatório incluir referência, procedência, finalidade e localização do documento". Retorna ao início da página;

8) Caso positivo, o sistema verifica se o campo "validade" foi preenchido e compara a informação com a data atual. Caso seja data anterior à atual ou o campo esteja em branco, apresenta mensagem "Data inválida". Retorna à página de início;

9) O sistema salva os dados, envia mensagem ao verificador e apresenta mensagem "Documento registrado com sucesso". Retorna à página de início;

10)Clicar em "Sair". O sistema fecha.

O fluxograma correspondente encontra-se na Figura 01. 
Figura 01 - Fluxograma "Inclusão de Documentos"

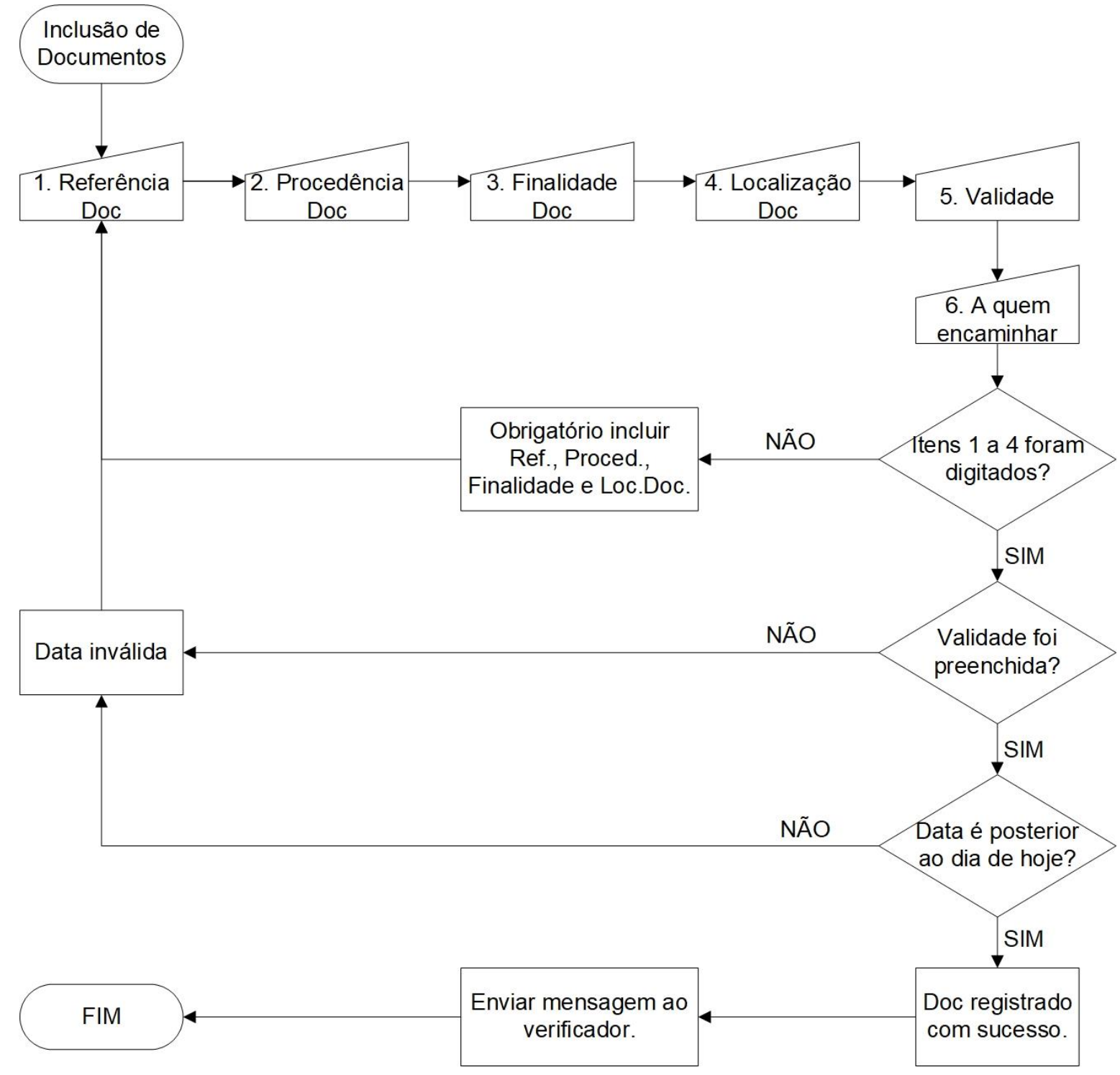

Legenda dos fluxogramas:

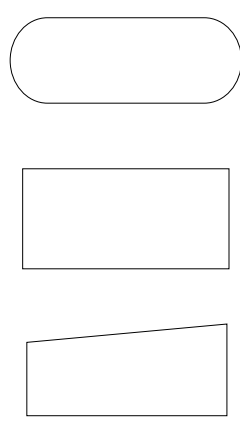

Início / fim

Processo

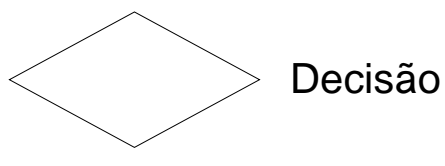

Entrada manual

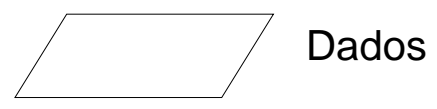

5.1.2 Página Consulta e Edição de Documentos

Itens a serem apresentados na página "Consulta e Edição de Documentos": 
- Título "Consulta de Documentos";

- Nome do usuário e data / horário de acesso;

- Botão "Pesquisar";

- Botão de escolha "Pesquisa por referência, procedência, finalidade ou localização do documento";

- Caixa de entrada "Dado a pesquisar";

- Caixa de entrada "Documento(s) pesquisado(s)";

- Botão "Modificar";

- Botão "Sair".

Operações elementares:

1) Digitar uma palavra-chave correspondente ao(s) documento(s) a ser(em) buscado(s);

2) Utilizar o botão de escolha para selecionar o campo de pesquisa a palavrachave digitada: por referência, procedência, finalidade ou localização do documento. Clicar em "Pesquisar";

3) O sistema busca a palavra-chave no campo de pesquisa selecionado na tabela correspondente. Caso não encontre nenhum item, aparece a mensagem "Nenhum item encontrado.". Retornar ao início da página "Consulta e Edição de Documentos".

4) $\mathrm{O}(\mathrm{s})$ item(ns) encontrado(s) é(são) listado(s) na caixa de entrada "Documento(s) Pesquisado(s)" (até 5 itens; para itens excedentes, cria-se uma barra de rolagem vertical à direita da lista);

5) Caso desejado, clicar em um dos itens listados e clicar em "Modificar";

6) Ao clicar em "Modificar", o sistema verifica qual item pesquisado foi selecionado; caso nenhum o tenha, aparece a mensagem "Nenhum item selecionado.".

7) Caso haja um item selecionado, o sistema traz os dados nos mesmos campos da página "Inclusão de Documentos", passíveis de modificações. O usuário modifica os valores de acordo e clica em "Salvar". O sistema atualiza a tabela correspondente. Retornar ao início da página de Consulta e Edição de Documentos. É enviada ao verificador notificação de modificação de documentos. 
8) Clicar em "Sair". O sistema fecha.

O fluxograma correspondente encontra-se na Figura 02.

Figura 02 - Fluxograma "Consulta e Edição de Documentos"

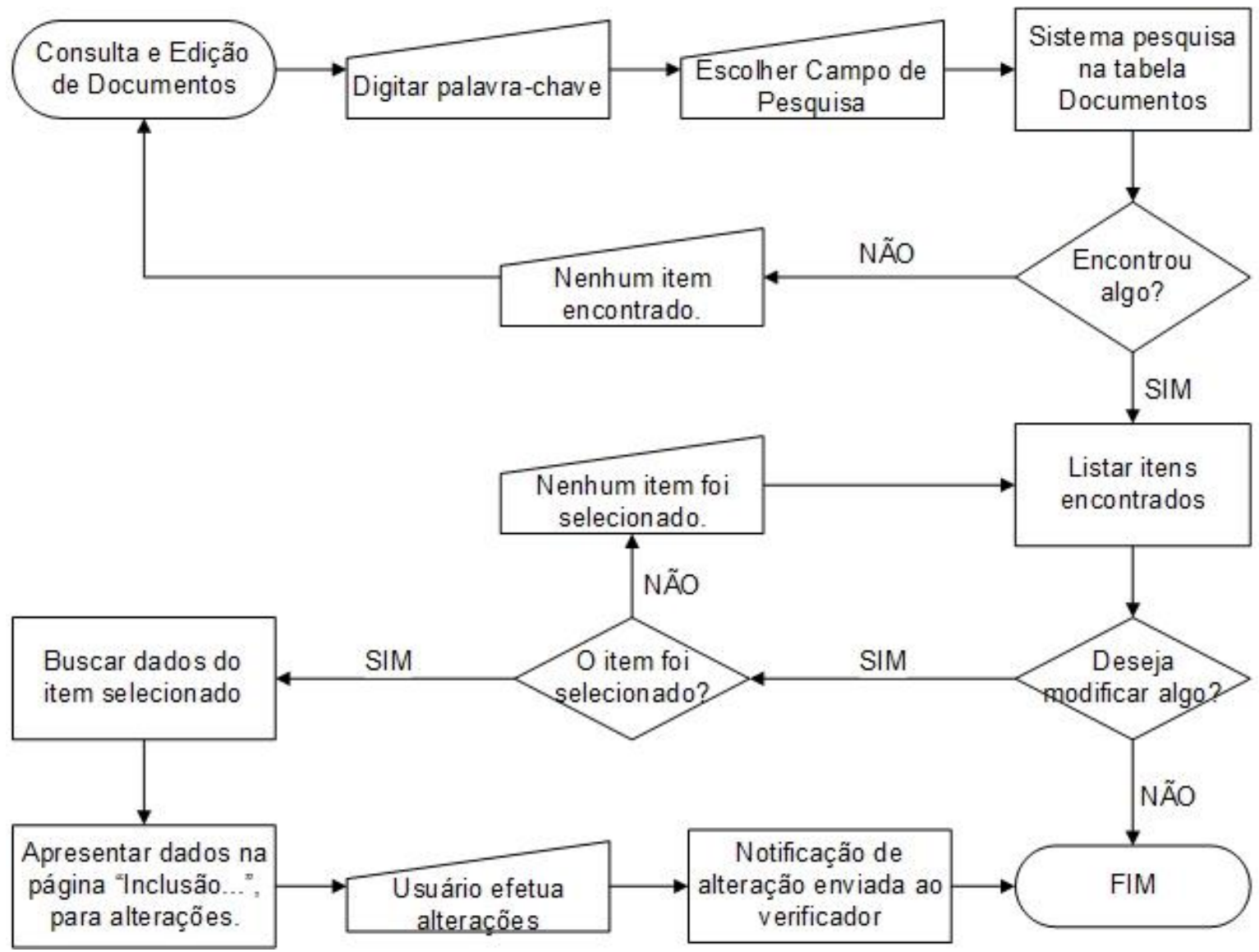

\subsubsection{Página Verificação de Documentos}

Itens a serem apresentados na página "Verificação de Documentos":

- Inicialmente, a página de Entrada;

- Depois, a página com o título "Verificação de Documentos";

- Caixa de texto com lista de itens a serem verificados (até 5);

- Botão "Aceito";

- Botão "Rejeitado";

- Botão "Cancelar";

- Botão "Sair";

- Caixa de texto "Documento aceito?" - incluir botões "Sim" e "Não". 
Operações elementares:

1) O verificador recebeu uma notificação de inclusão de documentos. Após ser autorizado via login e senha, ele abre a página "Verificação de Documentos".

2) Os documentos incluídos aparecem na página. O verificador seleciona o item e uma nova página abre, para análise dos dados. Na sequência, ele clica no botão "Aceito" ou "Rejeitado".

3) Se o verificador clicar em "Aceito", a informação de "verificado" é registrada na tabela correspondente, uma mensagem informativa é enviada para o autor do documento, e caso haja necessidade de aprovação, a notificação é enviada ao responsável pela mesma.

4) Caso o verificador clique em "Rejeitado", ele digita o motivo pelo qual o item foi rejeitado, e depois clica em "Enviar". Tal informação é registrada na tabela correspondente, e uma notificação é enviada para o autor do documento, para que este revise o mesmo.

O fluxograma correspondente encontra-se na Figura 03. 
Figura 03 - Fluxograma "Verificação de Documentos"

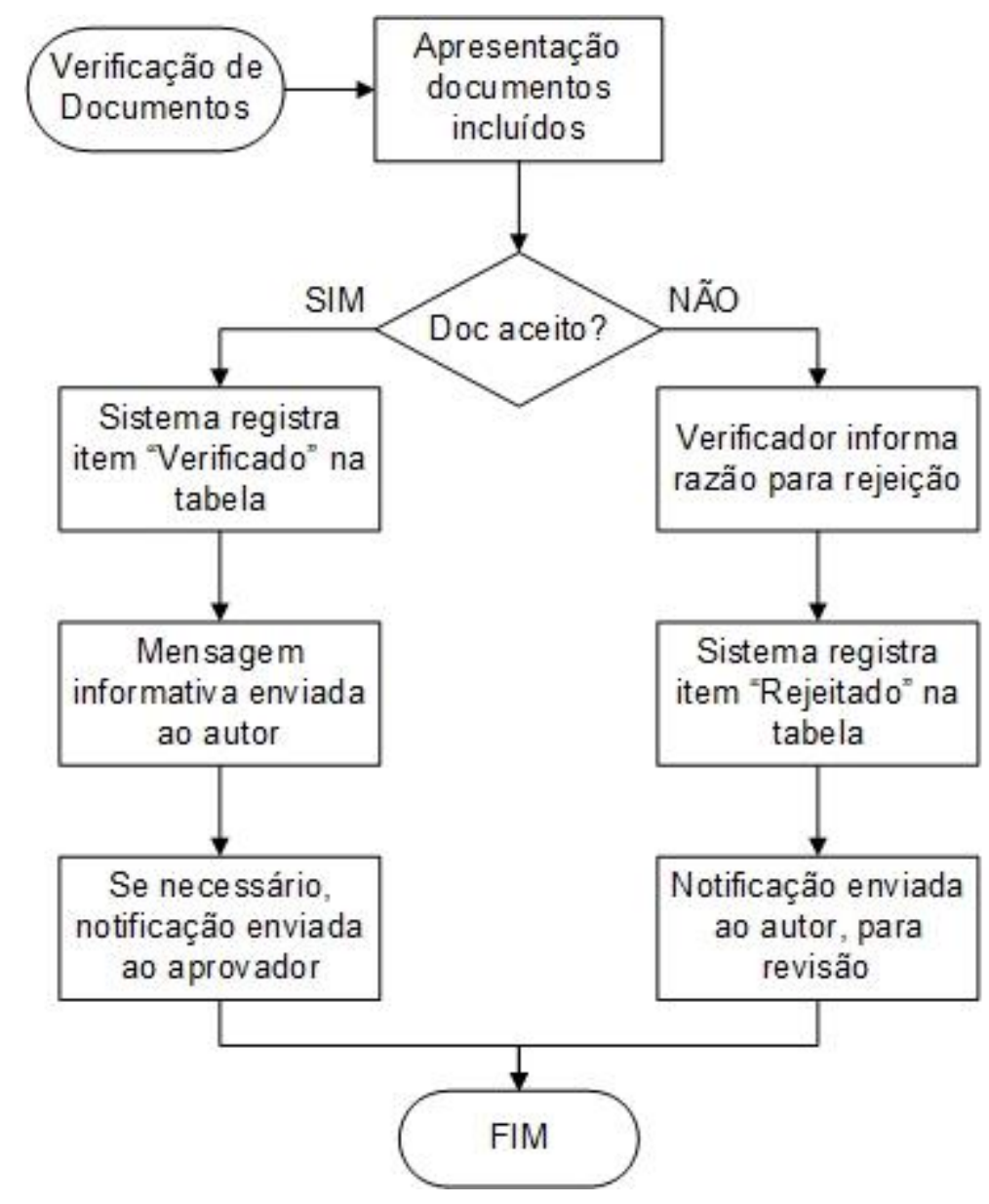

\subsubsection{Página Aprovação de Documentos}

Itens a serem apresentados na página "Aprovação de Documentos":

- Inicialmente, a página de Entrada;

- Depois, a página com o título "Aprovação de Documentos";

- Caixa de texto com lista de itens a serem aprovados (até 5);

- Botão "Aprovado";

- Botão "Recusado";

- Botão "Cancelar";

- Botão "Sair";

- Caixa de texto "Documento aprovado?" - incluir botões "Sim" e "Não";

- Caixa de texto "Documento recusado?" - incluir botões "Sim" e "Não".

Operações elementares: 
1) O aprovador recebeu uma notificação documento a ser aprovado. Após ser autorizado via login e senha, ele abre a página "Aprovação de Documentos".

2) Os itens verificados aparecem na página. O aprovador seleciona o item e analisa o documento. Na sequência, ele clica no botão "Aprovado" ou "Recusado".

3) Se o aprovador clicar em "Aprovado", a informação de "aprovado" é registrada na tabela, e mensagens informativas da aprovação final são enviadas para o autor do documento, bem como para seu verificador.

4) Caso o aprovador clique em "Recusado", ele digita o motivo pelo qual o item foi recusado, e depois clica em "Enviar". Tal informação é registrada na tabela, e notificações são enviadas para o autor do documento e para o verificador, para revisão.

O fluxograma correspondente encontra-se na Figura 04.

Figura 04 - Fluxograma "Aprovação de Documentos"

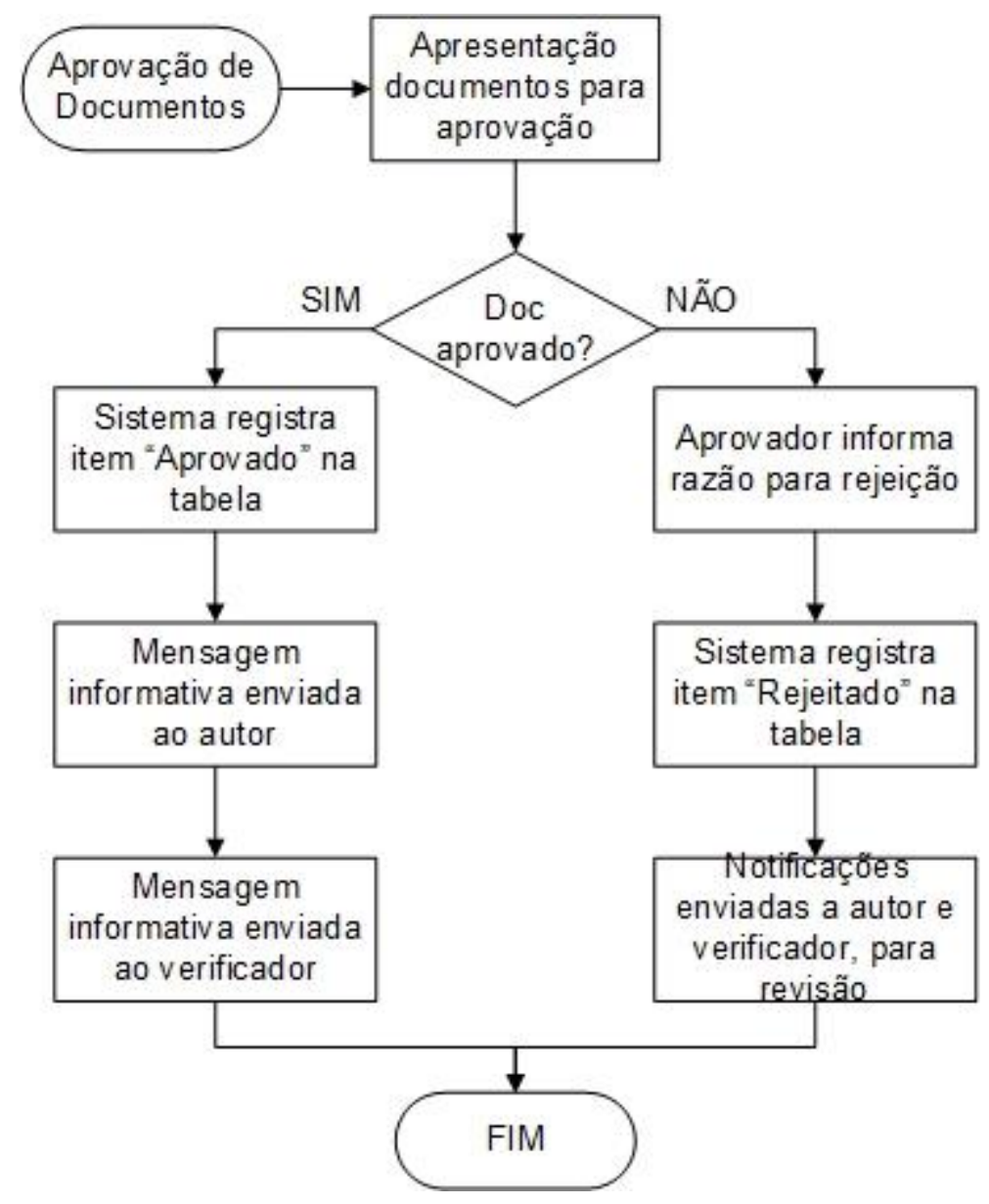




\subsection{Controle de Projeto}

Estes requisitos da CNEN-NN-1.16 estão especificados na seção 4.5 "Controle de Projeto". Esta seção está subdividida em quatro subseções referentes a requisitos gerais, interfaces, verificação e alterações de projeto. A seguir, segue a primeira subseção 4.5.1 "Requisitos Gerais":

4.5.1.1 Devem ser estabelecidas e documentadas medidas de controle de projeto para assegurar que os requisitos de projeto aplicáveis, tais como bases de projeto, normas e exigências da CNEN, sejam incorporados corretamente nas especificações, códigos computadorizados de projeto, desenhos, procedimentos ou instruções.

4.5.1.2 As medidas de controle de projeto devem assegurar que os requisitos de qualidade aplicáveis sejam especificados, incluídos ou referidos nos documentos de projeto.

4.5.1.3 As alterações e desvios dos requisitos de projeto e da qualidade especificados devem ser identificados, documentados e controlados.

4.5.1.4 Devem ser estabelecidas medidas de controle de projeto para a seleção e a análise da aplicabilidade do uso de quaisquer materiais, peças, equipamentos e processos que sejam essenciais para a função da estrutura, sistema ou componente.

4.5.1.5 Devem ser aplicadas, conforme a natureza da instalação, medidas de controle de projeto a tópicos tais como:

a) radioproteção;

b) física de reatores;

c) análises térmica, hidráulica, sísmica, de tensão e de acidente;

d) compatibilidade de materiais;

e) acessibilidade para inspeção em serviço, manutenção e reparo;

f) estabelecimento de critérios de aceitação para inspeções e testes.

4.5.1.6 As atividades de projeto devem ser documentadas para permitir avaliação adequada por pessoal técnico diverso daquele que tenha elaborado o projeto original. (CNEN, 2000).

O detalhamento realizado utilizando os itens correspondentes da regulação americana segue abaixo: 


\section{- Requisitos Gerais}

Os dados de entrada de projeto, tais como: suas bases, relatórios de projeto conceitual, requisitos regulamentares e de desempenho, códigos e padrões, devem ser controlados pelos responsáveis pelo projeto de acordo com os seguintes requisitos:

1. Os dados de entrada de projeto devem ser identificados e documentados e sua seleção revista e aprovada, por parte dos responsáveis pelo projeto.

2. Os dados de entrada de projeto devem ser especificados e aprovados em tempo hábil e com nível de detalhamento necessário que permita que o trabalho do projeto seja realizado corretamente e forneça uma base consistente para a respectiva tomada de decisões.

Os dados resultantes de investigações científicas, usados como entradas de projeto, devem ser qualificados de acordo com as normas e regulamentações da CNEN. Caso não sejam qualificados antes de sua utilização no projeto, devem ser identificados como tal e monitorados até a qualificação. Dados ainda não qualificados, especialmente os relacionados a questões de segurança ou isolamento de rejeitos, não podem ser usados para o licenciamento.

As alterações nos dados de entrada de projeto aprovados e as razões para tal devem ser identificadas, aprovadas, documentadas e controladas.

Dados de entrada de projeto baseados em premissas sujeitas à confirmação futura devem ser identificados e controlados ao longo do desenvolvimento do projeto.

\section{- Desenvolvimento do Projeto}

O desenvolvimento do projeto deve ser controlado conforme os seguintes requisitos:

O trabalho de projeto deve ser documentado em tempo hábil e com nível de detalhe necessário que permita que o seu desenvolvimento seja realizado corretamente e verifique-se que ele atende aos requisitos existentes.

Os documentos de projeto devem ser adequados para fornecer suporte ao projeto, fabricação, construção e operação. A documentação deve incluir não apenas os documentos finais do mesmo, tais como desenhos, especificações e 
suas revisões, mas também a documentação que identifique as etapas mais importantes, incluindo as fontes de entrada que embasem o projeto final.

As normas e padrões de controle de qualidade apropriados devem ser identificados e documentados e sua seleção revista e aprovada.

Alterações nas normas e padrões de controle de qualidade especificados, incluindo as razões para as mudanças ou desvios, devem ser identificadas, avaliadas, aprovadas, documentadas e controladas.

Devem ser estabelecidas medidas para a seleção e avaliação da adequação da aplicação de materiais, peças, equipamentos e processos referentes a estruturas, sistemas e componentes que sejam importantes para o isolamento de rejeitos e/ou importantes para a segurança.

As informações aplicáveis derivadas de experiência, conforme previsto em relatórios ou outra documentação, devem estar disponíveis para conhecimento do pessoal de projeto.

O projeto final (documentos de projeto aprovados e alterações devidamente registradas e aprovadas) deve:

1. estar relacionado com as entradas de projeto por meio da devida documentação, com detalhes suficientes que permitam tal verificação; e

2. identificar montagens e/ou componentes que fazem parte do item que está sendo projetado.

Se antes da instalação, um item de classe comercial for modificado ou selecionado para inspeção e/ou testes especiais para atender a exigências que sejam mais restritivas do que a descrição do produto publicada pelo fornecedor, o item deve ser registrado como diferente do item de classe comercial (item não conforme). Deve ser realizada uma descrição documentada das diferenças.

A precisão e a integridade dimensional dos desenhos de projeto e especificações devem ser verificadas e documentadas.

Desenhos de projeto, especificações e outros documentos de saída de projeto devem conter critérios apropriados de controle e aceitação de testes.

Quando especificado por meio de procedimentos de controle, os desenhos e as especificações de projeto devem ser revisados por indivíduos ou grupos, treinados e qualificados em práticas e conceitos de controle de qualidade, diferentes daqueles que criaram os documentos, para garantir que eles sejam 
preparados, revisados e aprovados de acordo com os documentos de implementação aplicáveis; e apresentem os requisitos necessários para controle de qualidade, tais como requisitos de inspeção e teste, e requisitos de aceitação, na medida em que os resultados da inspeção e teste sejam documentados.

\section{- Análises de Projeto}

As análises de projeto devem ser realizadas de forma planejada, controlada e documentada.

Os documentos de análise de projeto devem ser legíveis e de forma adequada para reprodução, arquivamento e recuperação.

Os documentos de análise de projeto devem ser suficientemente detalhados quanto a propósito, método, pressupostos, entradas de projeto, referências e unidades de tal forma que uma pessoa tecnicamente qualificada no assunto possa rever e compreender as análises e verificar a adequação dos resultados sem que seja necessário recorrer ao autor original.

Os cálculos devem ser identificáveis por assunto (incluindo estruturas, sistemas e componentes aos quais se aplicam os cálculos), autor, revisor e data, ou por outros indicadores de forma que os cálculos sejam rastreáveis e recuperáveis.

A documentação de análise de projeto deve incluir:

1. Definição do objetivo das análises.

2. Definição de entradas de projeto e suas fontes.

3. Resultados de pesquisas bibliográficas ou outros dados anteriores aplicáveis.

4. Identificação dos pressupostos e indicação daqueles que devem ser verificados no decorrer do projeto.

5. Identificação de qualquer cálculo computadorizado, incluindo tipo de computador, programa, identificação de revisão, entradas, saídas, evidência ou referência à verificação do programa de computador, e as bases (ou referência às mesmas) que recomendem a aplicação de tal programa para o problema físico específico.

6. Os programas de computador podem ser utilizados em análises de projeto sem a verificação individual do programa para cada aplicação, desde que: 
a - o programa tenha sido verificado para demonstrar que ele produz soluções corretas para o modelo matemático codificado dentro dos limites definidos para cada parâmetro empregado, e

b - comprove-se que o modelo matemático codificado produz uma solução válida para o problema físico relacionado à aplicação em particular.

7. Os programas de computador deverão ser controlados para garantir que as mudanças sejam documentadas e aprovadas por pessoal autorizado. No que houver alterações em programas já verificados anteriormente, uma nova verificação será exigida e documentada para a mudança, incluindo a avaliação dos efeitos dessas mudanças.

8. Identificação do autor, revisor e aprovador.

Em seguida, a segunda subseção 4.5.2 "Interfaces de Projeto":

4.5.2.1 Devem ser identificadas por escrito, as interfaces internas e externas entre organizações e unidades organizacionais que elaboram os projetos.

4.5.2.2 A responsabilidade de cada organização e unidade organizacional deve ser definida com suficiente detalhe para abranger a preparação, verificação, aprovação, validação, liberação, distribuição e revisão de documentos que envolvam interfaces de projeto.

4.5.2.3 Devem ser estabelecidos métodos para comunicação documentada e controlada de informações do projeto, inclusive alterações do mesmo, através das interfaces de projeto entre organizações e unidades organizacionais. (CNEN, 2000).

O detalhamento realizado utilizando os itens correspondentes da regulação americana está abaixo:

- Controle de Interface de Projeto

As interfaces de projeto devem ser identificadas e controladas.

As ações de projeto devem ser coordenadas entre suas organizações participantes e por instruções técnicas. Controles de interface devem incluir a atribuição de responsabilidades e a implementação de documentos entre as organizações participantes do projeto, bem como instruções técnicas, para a 
análise, aprovação, liberação, distribuição e revisão de documentos envolvendo interfaces de projeto, para garantir que as estruturas, sistemas e componentes sejam devidamente compatíveis, funcionais, com procedimentos e positivamente ambientais.

As informações de projeto transmitidas através das interfaces devem ser documentadas e controladas.

A situação da informação de projeto ou documento fornecido deve ser identificada nas transmissões.

Quando for necessário transmitir informações de projeto inicialmente por via oral ou outros meios informais, a transmissão de informações de projeto deve ser prontamente confirmada e controlada com documentação formal iniciada em conformidade com a documentação inicialmente aprovada pela organização.

Em seguida, a terceira subseção 4.5.3 "Verificação de Projeto":

4.5.3.1 As medidas de controle de projeto devem assegurar a verificação da adequação do projeto através da realização de análises do mesmo, do uso de métodos de cálculo alternativos ou pela execução de um programa adequado de ensaios e testes.

4.5.3.2 A verificação de projeto deve ser realizada por pessoas ou grupos diferentes daqueles que elaboraram o projeto original.

4.5.3.3 A organização responsável pela verificação de projeto deve identificar os métodos a serem aplicados na verificação e documentar os respectivos resultados.

4.5.3.4 No caso de se utilizar um programa de testes para verificar a adequação de uma característica específica do projeto, ao invés de outros processos de verificação ou controle, tal programa deve incluir testes adequados de qualificação de um protótipo sob as condições de projeto mais adversas para a característica específica de projeto a ser verificada.

4.5.3.5 No caso de impossibilidade dos testes de qualificação referidos na subseção anterior serem realizados sob as condições de projeto mais adversas, sua realização será admissível sob outras condições se os resultados puderem:

a) ser extrapolados para as condições de projeto mais adversas; $e$

b) comprovar a adequação de uma característica específica de projeto. (CNEN, 2000). 
O detalhamento realizado utilizando os itens correspondentes da regulação americana segue abaixo:

\section{- Verificação de Projeto}

A verificação de projeto deve ser efetuada para determinar sua adequação, por um ou uma combinação dos seguintes métodos:

1. Revisão de projeto.

2. Cálculos simplificados ou alternativos.

3. Teste de qualificação.

A extensão da verificação de projeto requerida deve ser em função da importância das estruturas, sistemas e componentes importantes para a segurança e isolamento de rejeitos a serem considerados, da complexidade do projeto, do grau de padronização, da tecnologia disponível, e da semelhança com projetos previamente comprovados.

Orientações ou critérios devem ser estabelecidos e descritos para determinar o método de verificação do projeto. $O$ método específico de verificação do projeto utilizado deve ser identificado e documentado.

Controles de processos devem fornecer critérios para determinar quando os documentos do projeto, que refletem os compromissos com o relatório de análise de segurança, recebem verificação oficial de projeto, seja por uma equipe ou por um único indivíduo (assinatura e data são documentação suficiente). Documentos de projeto sujeitos a controles de processos incluem: especificações, cálculos, programa de computador que apoie a função de segurança ou isolamento de rejeitos, descrições do sistema, partes de relatório de análise de segurança quando utilizadas como documento de projeto, e desenhos, incluindo diagramas de fluxo, tubulação e diagramas instrumentais, diagramas lógicos de controle, diagramas de linha elétrica única, sistemas estruturais para grandes instalações e localizações dos equipamentos. Publicações especializadas podem ser utilizadas quando considerações específicas de projeto ou a especialização exijam.

Os resultados da verificação de projeto devem ser documentados, inclusive a identificação do verificador. 
As responsabilidades do verificador, áreas e recursos a serem verificados, considerações pertinentes, e a extensão da documentação devem ser identificadas em procedimentos.

A verificação do projeto deve ser realizada por pessoal ou por grupos técnicos competentes diferentes daqueles que realizaram o projeto original, mas que poderão ser da mesma organização. Em circunstâncias excepcionais, tal verificação pode ser realizada pelo supervisor imediato, desde que:

1. O supervisor não tenha especificado uma abordagem única de projeto ou tenha descartado certas considerações de projeto e não tenha estabelecido os dados de entrada utilizados no projeto.

2. O supervisor seja o único indivíduo na organização competente para realizar tal verificação.

3. A verificação não seja uma análise superficial.

4. A determinação de se utilizar o supervisor esteja documentada e previamente aprovada pela gerência do supervisor.

5. Auditorias de controle de qualidade sejam realizadas para avaliar a frequência e eficácia do uso de supervisores como verificadores de projeto.

A verificação de projeto deve ser realizada em tempo hábil.

1. A verificação de projeto, pelo nível de atividade do projeto efetuado, deve ser realizada antes da liberação para aquisição, fabricação, construção, ou liberação para outra organização para utilização em outro trabalho de projeto. Nos casos em que esse período não possa ser cumprido, ou caso os dados sejam insuficientes, a parte não verificada do projeto deve ser identificada e controlada. A justificativa para tal ação deve ser documentada.

2. Em todos os casos, a verificação do projeto deve ser concluída antes de se colocar em operação quaisquer estruturas, sistemas e componentes relacionados à segurança.

Quando o projeto já tiver sido submetido a um processo de verificação anterior de acordo com a CNEN, o processo de verificação não precisará ser repetido em modelos idênticos.

O uso de projetos previamente comprovados deve ser controlado de acordo com os seguintes requisitos: 
1. A aplicabilidade de projetos padronizados ou previamente comprovados, no que diz respeito ao cumprimento das entradas de projeto pertinentes, deve ser verificada e documentada.

2. Problemas conhecidos que afetam projetos padronizados ou previamente comprovados e seus efeitos sobre outras características devem ser considerados.

3. O projeto original e as medidas de verificação associadas devem ser adequadamente documentados e referenciados nos arquivos da aplicação posterior do projeto.

Se tiverem sido feitas alterações em um projeto anteriormente verificado, sua verificação será necessária para as alterações, incluindo avaliação dos efeitos destas sobre a concepção global.

- Métodos de verificação do projeto

A - Revisão de Projeto

As revisões de projeto devem ser controladas e realizadas para garantir que:

1. As entradas de projeto sejam corretamente selecionadas e incorporadas.

2. Os pressupostos necessários para executar o projeto sejam adequadamente descritos, razoáveis e, quando aplicáveis, identificados como necessitando de confirmação conforme o projeto avança.

3. Métodos de projeto apropriados e programas de computador, quando aplicáveis, tenham sido utilizados.

4. Entradas de projeto sejam corretamente incorporadas ao projeto.

5. As saídas de projeto sejam razoáveis em comparação com as entradas do mesmo.

6. Os requisitos de entrada e verificação de projeto, necessários para as organizações de interface, tenham sido especificados nos documentos de projeto ou em documentos de apoio à implementação.

B - Cálculos simplificados ou alternativos:

Tratam-se de cálculos ou análises que são feitos com métodos alternativos para verificar a exatidão dos cálculos ou análises originais. A 
adequação de suposições, os dados utilizados, bem como o programa de computador ou outro método de cálculo utilizado também devem ser revisados.

C - Teste de qualificação

1. Quando a adequação do projeto tiver de ser verificada por meio de testes de qualificação, o método para testes deve ser identificado.

2. Testes de protótipos, componentes ou recursos devem ser realizados o mais breve possível antes da instalação.

3. A configuração de testes deve ser definida e documentada.

4. Os testes devem demonstrar a adequação do desempenho de estruturas, sistemas e componentes em condições que simulem todas as possibilidades, inclusive nas condições mais adversas de projeto esperadas, conforme determinado pela análise. Os modos de operação e as condições ambientais nas quais o item deverá funcionar satisfatoriamente devem ser considerados na determinação das condições mais adversas.

5. Sempre que o teste se destinar a verificar apenas características de projeto específicas, as outras características do projeto devem ser verificadas por outros meios.

6. Os resultados dos testes devem ser documentados e avaliados pela organização de projeto responsável, para garantir que os requisitos de teste tenham sido cumpridos.

7. Se o teste de qualificação indicar que alterações em um item sejam necessárias para obtenção de um desempenho aceitável, a alteração deve ser documentada e o item modificado é novamente testado ou verificado para garantir o desempenho satisfatório.

8. Quando os testes forem realizados em modelos ou protótipos, leis de escala devem ser estabelecidas, verificadas e aprovadas.

9. Os resultados do trabalho de testes do modelo devem estar sujeitos à análise de erros, quando aplicável, antes de se utilizar os resultados no projeto final.

Por último, a quarta subseção 4.5.4 "Alterações de Projeto": 
4.5.4.1 Devem ser estabelecidos procedimentos documentados para efetuar alterações de projeto, inclusive alterações no campo.

4.5.4.2 As consequências técnicas das alterações de projeto devem ser cuidadosamente examinadas e as ações exigidas documentadas.

4.5.4.3 As alterações de projeto devem estar sujeitas às mesmas medidas de controle aplicadas ao projeto original.

4.5.4.4 Os documentos de alterações de projeto devem ser analisados e aprovados pelos mesmos grupos ou organizações responsáveis pela análise e aprovação dos documentos originais de projeto, a menos que outras organizações sejam especificamente designadas.

4.5.4.5 A designação de organizações alternativas para análise e aprovação de documentos de alterações de projeto deve estar condicionada a terem:

a) competência na área sob revisão e entendimento adequado dos requisitos e propósitos do projeto original;

b) acesso às informações necessárias às atividades de projeto envolvidas.

4.5.4.6 As informações concernentes às alterações de projeto devem ser transmitidas a todas as pessoas $e$ organizações envolvidas. (CNEN, 2000).

O detalhamento realizado utilizando os itens correspondentes da regulação americana está abaixo:

- Controle de Alterações de Projeto

As alterações de projeto, incluindo alterações de campo, devem ser controladas de acordo com os seguintes requisitos:

Alterações em projetos finais, alterações de campo e itens não conformes definidos por "como construído" ou reparados, devem ser justificadas e estarão sujeitas a medidas de controle de projeto compatíveis com as aplicadas ao projeto original.

As alterações devem ser aprovadas pelos mesmos grupos ou organizações que analisaram e aprovaram os documentos de projeto originais.

1. No caso de a organização, que era originalmente responsável pela aprovação de um documento de projeto específico, já não ser mais a responsável, o diretor ou seu representante deve indicar uma nova organização para tal. 
2. A organização aprovada deve demonstrar competência nas áreas de interesse específicas do projeto, bem como ter uma compreensão adequada dos requerimentos e objetivos do projeto original.

Quando for necessária uma alteração significativa por causa de um projeto incorreto, o processo do projeto e os documentos de verificação devem ser revistos e modificados conforme necessário.

Erros ou deficiências em documentos de projeto aprovados, inclusive métodos de projeto (ex.: programa de computador com função de segurança ou de isolamento de rejeitos) que possam afetar adversamente as estruturas, sistemas e componentes importantes para a segurança ou proteções importantes para $\mathrm{o}$ isolamento de rejeitos, devem ser documentados e as medidas tomadas para garantir que todos os erros e deficiências sejam corrigidos.

Os desvios padrões de qualidade especificados devem ser identificados e documentados formalmente. Devem ser estabelecidos procedimentos para assegurar o controle desses desvios.

Devem ser fornecidas medidas para garantir que o pessoal seja notificado quanto às substituições / modificações de projeto que possam afetar o desempenho de suas funções.

As páginas a seguir são a de "Inclusão de Dados de Entrada" e a de "Consulta e Edição de Documentos", utilizadas pelo executor; "Verificação de Documentos", utilizada pelo verificador; e "Aprovação de Documentos", a ser utilizada pelo gerente.

\subsubsection{Página Inclusão de Dados de Entrada}

Itens a serem apresentados na página "Inclusão de Dados de Entrada":

- Título "Inclusão de Dados de Entrada";

- Nome do usuário e data / horário de acesso;

- Caixa de entrada "Estrutura" com a lista das já incluídas, com um botão "Adicionar Estrutura". Ao clicá-lo, a lista é substituída por uma caixa de texto em branco, para inclusão de novo dado;

- Caixa de entrada "Componente";

- Caixa de entrada "Elemento";

- Caixa de entrada "Valor"; 
- Caixa de entrada "Referências";

- Caixa de texto com lista de Componentes recém adicionados (até 5);

- Botão "Salvar";

- Botão "Cancelar";

- Botão "Sair".

Operações elementares:

1) Escolher qual "Estrutura" ou digitar uma nova;

2) Digitar:
a. "Componente";
b. "Elemento",
c. "Valor";
d. "Referências";

3) Clicar em "Salvar". O sistema verifica se há algum campo em branco. Caso positivo, apresentar mensagem "Não pode haver campos em branco.";

4) Caso negativo, apresentar mensagem "Deseja incluir mais Referências?". Caso positivo, salvar na tabela correspondente, limpar campos "Referências". Copiar dados "Estrutura", "Componente", "Elemento", "Valor" do item recém gravado; retornar à linha 2-d.;

5) Caso negativo, salvar na tabela "Dados de Entrada", apresentar mensagem "Deseja incluir mais Elementos?". Caso positivo, salvar na tabela correspondente, limpar campos "Elemento", "Referências". Copiar dados "Estrutura", "Componente" do item recém gravado; retornar à linha 2-b.;

6) Caso negativo, salvar na tabela correspondente, apresentar mensagem "Deseja incluir mais Componentes?". Caso positivo, salvar na tabela correspondente, limpar campos "Componente", "Elemento", "Referências". Copiar dados "Estrutura" do item recém gravado; retornar à linha 2-a.;

7) Caso negativo, salvar na tabela correspondente. Retornar ao início da página "Inclusão de Dados de Entrada". É enviada ao verificador notificação de inclusão de dados de entrada.

8) Clicar em "Sair". O sistema fecha. 
Figura 05 - Fluxograma "Inclusão de Dados de Entrada"

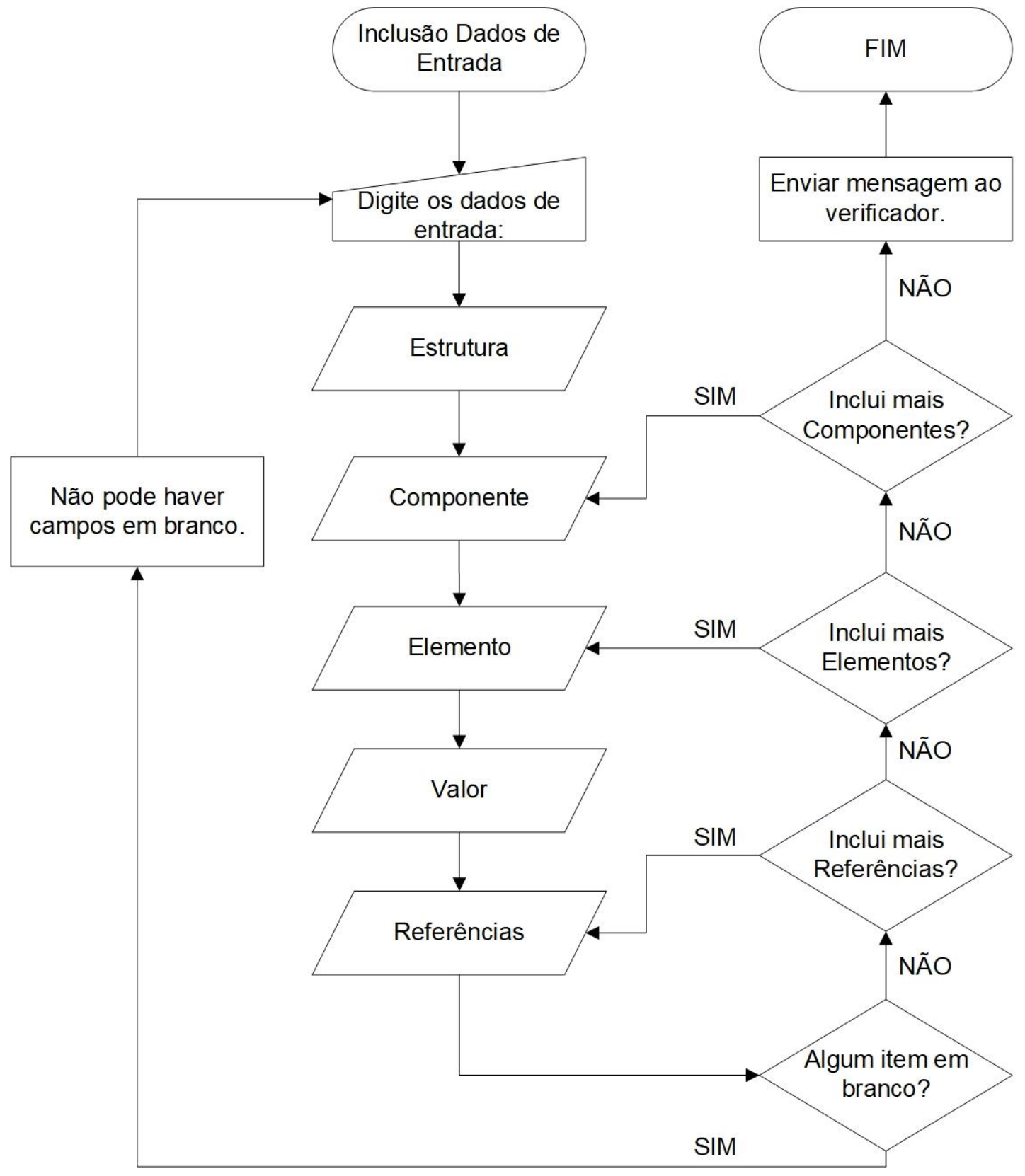

5.2.2 Página Consulta e Edição de Dados de Entrada

Itens a serem apresentados na página "Consulta e Edição de Dados de

Entrada":

- Título "Consulta e Edição de Dados de Entrada";

- Nome do usuário e data / horário de acesso;

- Caixa de Entrada "Item a pesquisar";

- Botão "Pesquisar"; 
- Caixa de entrada "Campo de pesquisa", com escolha entre Estrutura, Componente, Elemento ou Referências;

- Caixa de entrada "Item(ns) pesquisado(s)";

- Botão "Modificar";

- Botão "Sair".

Operações elementares:

1) Digitar na caixa de entrada "Item a pesquisar" o dado a ser pesquisado. Escolher o "Campo de pesquisa". Clicar em "Pesquisar";

2) O sistema pesquisa $o$ item na coluna correspondente ao campo de pesquisa selecionado da tabela correspondente. Caso não encontre nenhum item, aparece a mensagem "Nenhum item encontrado.". Retornar ao início da página "Pesquisa e Edição de Dados de Entrada".

3) $\mathrm{O}(\mathrm{s})$ item(ns) encontrado(s) é(são) listado(s) na Caixa de entrada "Item(ns) Pesquisado(s)" (até 5 itens; para itens excedentes, cria-se uma barra de rolagem vertical à direita da lista);

4) Caso desejado, clicar em um dos itens listados e clicar em "Modificar";

5) Ao clicar em "Modificar", o sistema verifica qual item pesquisado foi selecionado; caso nenhum o tenha, aparece a mensagem "Nenhum item selecionado.".

6) Caso haja um item selecionado, o sistema traz os dados nos mesmos campos da página "Inclusão de Dados de Entrada", passíveis de modificações. O usuário modifica os valores de acordo e clica em "Salvar". O sistema atualiza a tabela. Retornar ao início da página "Pesquisa e Edição de Dados de Entrada". É enviada ao verificador notificação de modificação de dados de entrada.

7) Clicar em "Sair". O sistema fecha.

O fluxograma correspondente encontra-se na Figura 06. 
Figura 06 - Fluxograma "Consulta e Edição de Dados de Entrada"

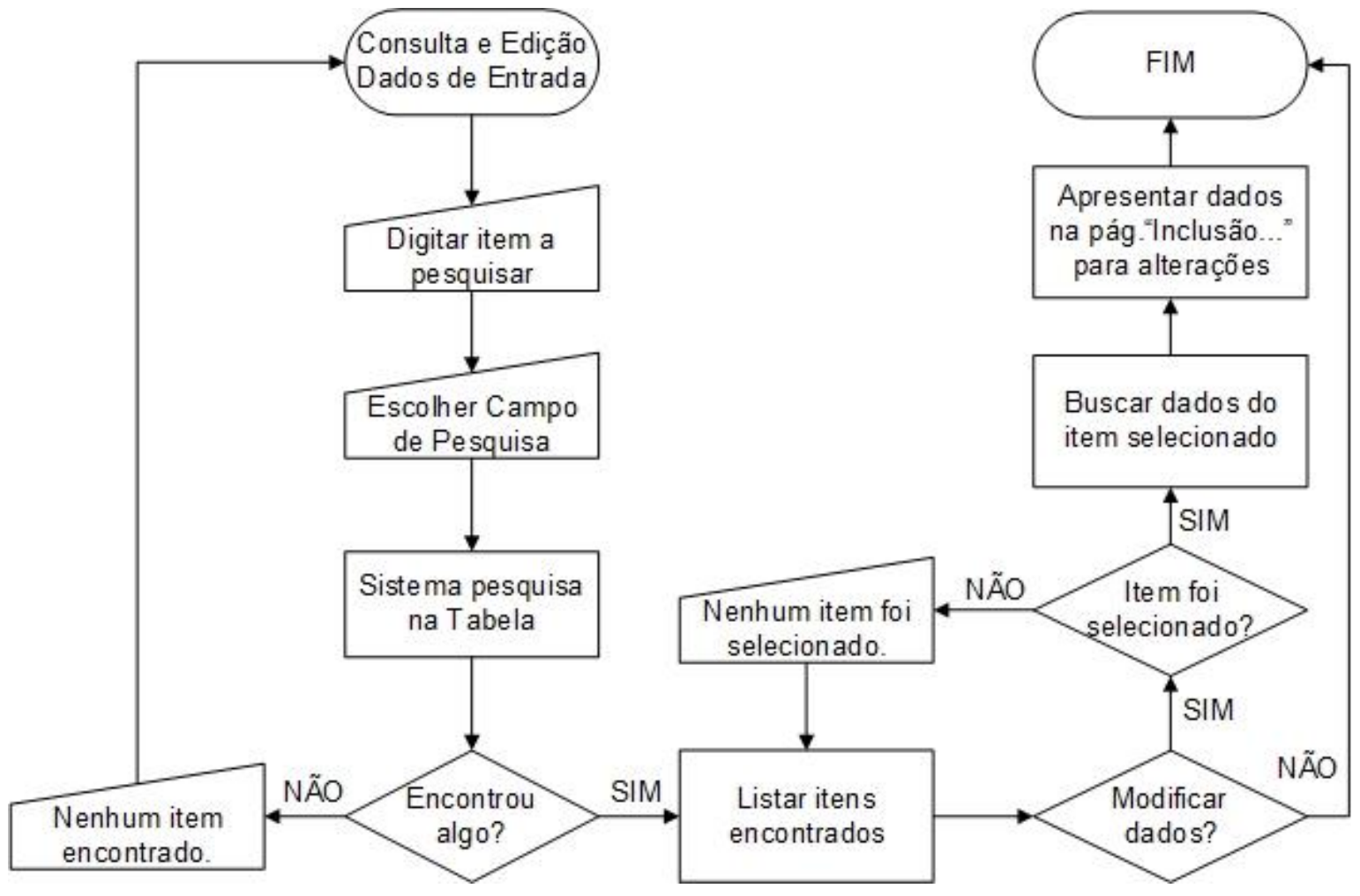

\subsubsection{Página Verificação de Dados de Entrada}

Itens a serem apresentados na página "Verificação de Dados de Entrada":

- Inicialmente, a página de Entrada;

- Depois, a página de Consulta e Edição de Dados de Entrada, com o título "Verificação de Dados de Entrada";

- Caixa de texto com lista de itens a serem verificados (até 5);

- Botão "Aceito";

- Botão "Rejeitado";

- Botão "Cancelar";

- Botão "Sair".

Operações elementares:

1) O verificador recebeu uma notificação de inclusão ou alteração de dados de entrada de base de projeto. Após ser autorizado via login e senha, ele abre a página "Verificação de Dados de Entrada". 
2) Os itens incluídos e alterados aparecem na página. O verificador seleciona o item e analisa os dados. Na sequência, ele clica no botão "Aceito" ou "Rejeitado".

3) Se o verificador clicar em "Aceito", uma mensagem informativa é enviada para o autor dos dados, e uma notificação é enviada ao responsável pela aprovação final.

4) Caso o verificador clique em "Rejeitado", ele digita o motivo pelo qual o item foi rejeitado, e depois clica em "Enviar". Tal informação é registrada no banco de dados, e uma notificação é enviada para o autor dos dados, para que este revise os mesmos.

O fluxograma correspondente encontra-se na Figura 07.

Figura 07 - Fluxograma "Verificação de Dados de Entrada"

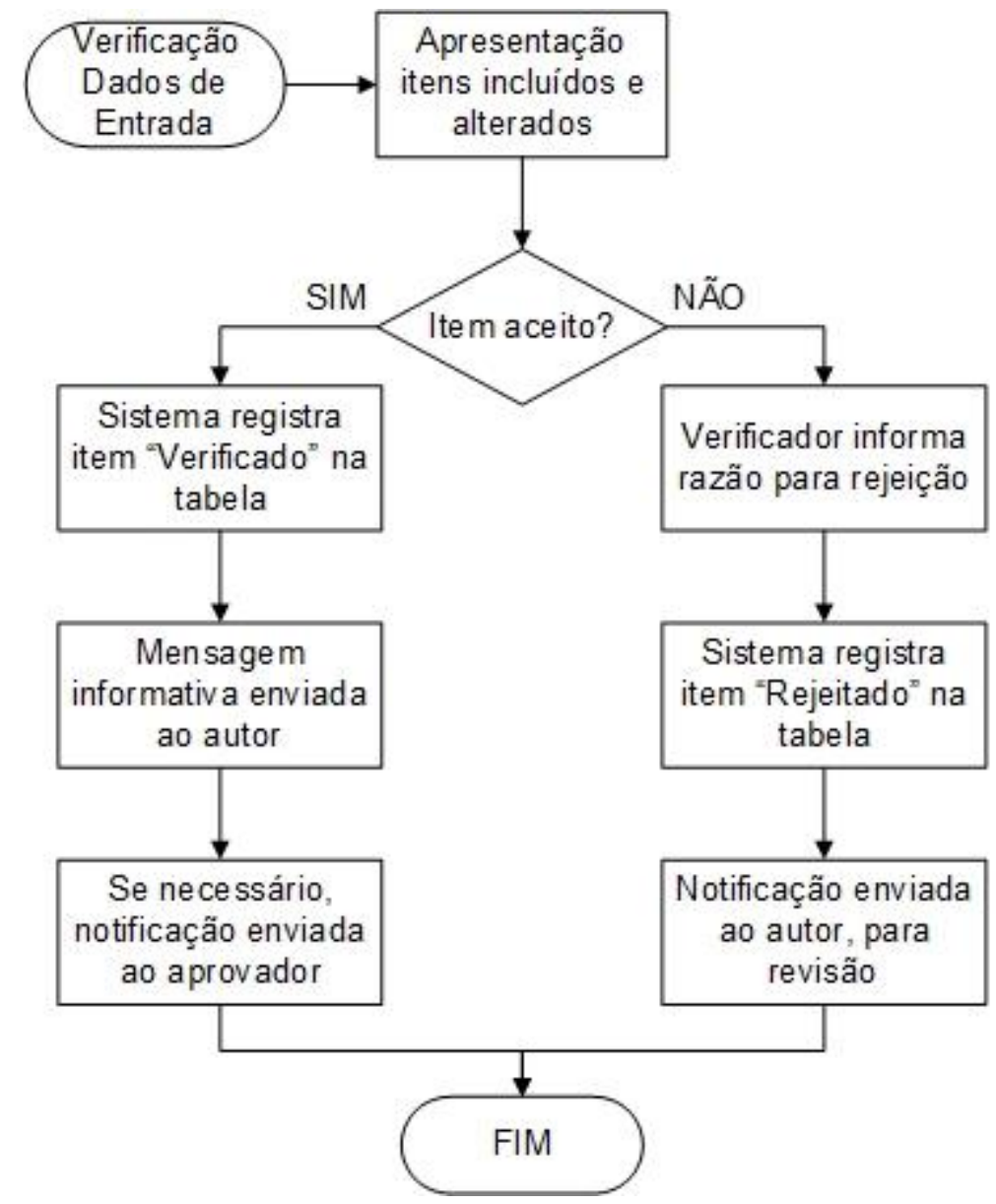


5.2.4 Página Aprovação de Dados de Entrada

Itens a serem apresentados na página "Aprovação de Dados de Entrada":

- Inicialmente, a página de Entrada;

- Depois, a página com o título "Aprovação de Dados de Entrada";

- Caixa de texto com lista de itens a serem aprovados (até 5);

- Botão "Aprovado";

- Botão "Recusado";

- Botão "Cancelar";

- Botão "Sair".

Operações elementares:

1) O aprovador recebeu uma notificação de dados de entrada de base de projeto verificados. Após ser autorizado via login e senha, ele abre a página "Aprovação de Dados de Entrada".

2) Os itens verificados aparecem na página. $O$ aprovador seleciona $o$ item $e$ analisa os dados. Na sequência, ele clica no botão "Aprovado" ou "Recusado".

3) Se o aprovador clicar em "Aprovado", a informação de "aprovado" é registrada no banco de dados, e mensagens informativas da aprovação final são enviadas para o autor dos dados e o verificador.

4) Caso o aprovador clique em "Recusado", ele digita o motivo pelo qual o item foi recusado, e depois clica em "Enviar". Tal informação é registrada no banco de dados, e notificações são enviadas para o autor dos dados e para o verificador, para revisão.

O fluxograma correspondente encontra-se na Figura 08. 
Figura 08 - Fluxograma "Aprovação de Dados de Entrada"

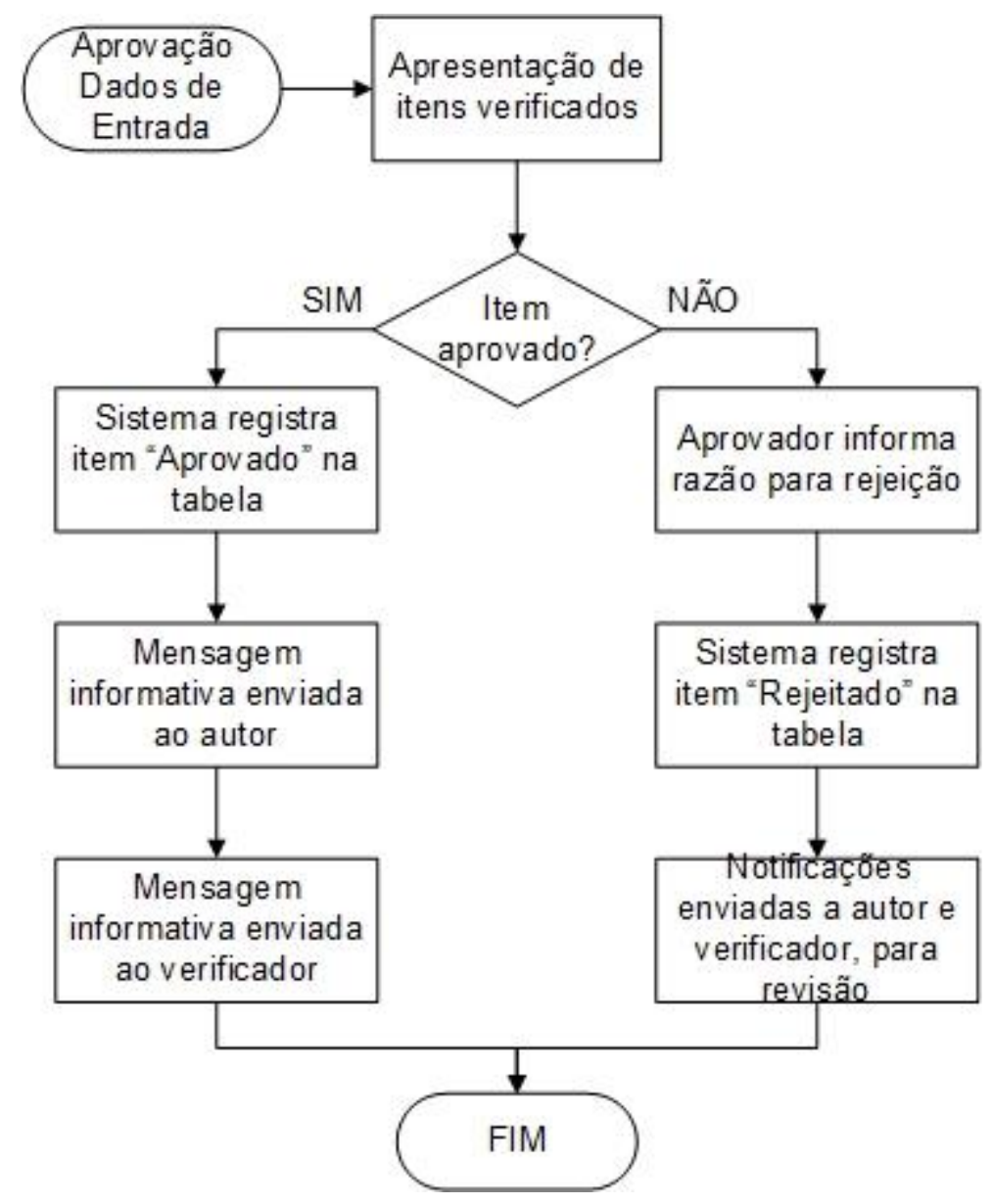

\subsection{Controle de Aquisições}

Estes requisitos da CNEN-NN-1.16 estão especificados na seção 4.6 "Controle de Aquisições". Esta seção está subdividida em três subseções referentes a requisitos gerais, avaliação e seleção de fornecedores, e o controle de itens e serviços adquiridos. A seguir, segue a primeira subseção 4.6.1 "Requisitos Gerais":

4.6.1.1 Devem ser estabelecidas e documentadas medidas para assegurar que as exigências da CNEN, bases de projeto, normas, códigos, especificações e outras exigências necessárias para garantir a qualidade requerida sejam incluídas ou referidas nos documentos de aquisição de itens e serviços.

4.6.1.2 Os documentos de aquisição de itens e serviço $s$ devem incluir, no mínimo, conforme seja aplicável: 
a) definição do escopo do trabalho a ser realizado pelo fornecedor;

b) requisitos técnicos e da qualidade especificados por referência a documentos tais como normas, códigos e exigências da CNEN, procedimentos, instruções e especificações, incluindo as revisões ou edições aplicáveis que descrevem os itens ou serviços;

c) requisitos de ensaio /testes, inspeção e aceitação e quaisquer instruções e exigências especiais para essas atividades;

d) cláusulas para acesso às instalações e registros do fornecedor para fins de inspeção e auditoria na fonte, quando for decidida a necessidade de tal inspeção e auditoria ;

e) identificação das exigências de Garantia da Qualidade aplicáveis aos itens ou serviços a serem adquiridos;

f) identificação da documentação exigida, tais como, instruções, procedimentos, especificações e registros de inspeções e testes, e outros registros de garantia da qualidade a serem preparados e submetidos à análise e aprovação do comprador;

g) cláusulas para que sejam efetuadas, de maneira controlada, a distribuição, retenção, manutenção e destinação dos registros de Garantia da Qualidade ;

h) requisitos para relatar e aprovar a destinação das não conformidades, incluindo a notificação ao comprador sobre os itens não conformes aceitos, que envolvam desvios em relação aos requisitos de aquisição;

i) cláusulas para estender os requisitos aplicáveis a subcontratadas e a seus fornecedores, incluindo o acesso do comprador às suas instalações e registros;

j) cláusulas para especificar o prazo da submissão dos documentos referidos na alínea f). (CNEN, 2000).

O detalhamento realizado utilizando os itens correspondentes da regulação americana segue abaixo:

- Controle de Aquisições de Materiais, Equipamentos e Serviços

Esta seção estabelece os requisitos para a qualidade no planejamento e execução de aquisições, visando garantir que os itens e serviços adquiridos atendam aos requisitos especificados. Os requisitos de avaliação e seleção de fornecedores e de propostas/licitações desta seção não se aplicam a situações quando a instalação de gestão de rejeitos radioativos obtém os serviços de outras agências federais, por meio de convênio interinstitucional ou outro acordo semelhante. Quando um convênio interinstitucional ou outro acordo servir como 
documento de aquisição entre o departamento de rejeitos radioativos e outras agências federais, os requisitos técnicos e de qualidade, responsabilidades e interfaces especificadas nesses documentos devem ser verificados para que sejam corretamente incorporados ao documento de controle de qualidade do programa da CNEN, antes do início do trabalho sujeito ao SGQ.

Os requerimentos desta seção que são aplicáveis aos fornecedores também são aplicáveis aos contratados da unidade de gestão de rejeitos radioativos, salvo indicação em contrário.

- Planejamento de Aquisições

As aquisições devem ser planejadas e documentadas para garantir uma abordagem sistemática do processo de aquisição. $O$ planejamento das aquisições deve:

Identificar métodos de aquisição e responsabilidades organizacionais (ex.: interfaces entre o projeto e a aquisição).

Identificar o que precisa ser feito, quem vai realizá-lo, como deve ser feito, e quando será realizado.

Antes do início de cada atividade, identificar e documentar a sequência de ações e metas, indicando a conclusão destas atividades e a preparação dos procedimentos aplicáveis.

Promover a integração das seguintes atividades:

1. Preparação de documentos de aquisição, revisão e controle de alterações de acordo com as exigências desta seção.

2. Seleção de fontes para aquisição.

3. Análise e escolha da proposta/licitação.

4. Avaliação de desempenho do contratado / fornecedor do departamento de rejeitos radioativos.

5. Verificações, incluindo todas as notificações de ponto de espera e testemunha.

6. Controle de não conformidades.

7. Ações corretivas.

8. Aceitação do item ou serviço.

9. Identificação dos registros de controle de qualidade. 
Realizar o controle das atividades de aquisição necessárias assim que possível e o mais tardar antes de seu início, visando garantir a compatibilidade de interface e uma abordagem uniforme do processo de aquisição.

Que seja realizado conforme o nível de importância, complexidade e quantidade do item ou serviço a ser comprado e o desempenho de qualidade do fornecedor.

Incluir a participação de representantes de organizações técnicas e indivíduos que sejam treinados e qualificados em práticas e conceitos de garantia da qualidade.

Em seguida, a segunda subseção 4.6.2 "Avaliação e Seleção de Fornecedores":

4.6.2.1 Na seleção de fornecedores deve ser avaliada a sua capacidade de fornecer itens ou serviços de acordo com os requisitos dos documentos de aquisição.

4.6.2.2 A avaliação do fornecedor deve incluir, conforme o caso:

a) o uso de dados históricos de desempenho da qualidade em atividades de aquisição similares;

b) o uso de documentos comprobatórios da qualidade atual do fornecedor, apoiados em informações, quantitativas ou qualitativas, que possam ser avaliadas objetivamente;

c) a avaliação na fonte, da capacidade técnica e do sistema da qualidade do fornecedor;

d) a avaliação de produtos por amostragem seletiva. (CNEN, 2000).

O detalhamento realizado utilizando os itens correspondentes da regulação americana segue abaixo:

\section{- Avaliação e Seleção de Origem}

A seleção de fornecedores deve ser baseada em uma avaliação, realizada pelo comprador antes da assinatura do contrato, para determinar a capacidade do fornecedor de fornecer produtos ou serviços de acordo com os requerimentos dos documentos de aquisição. 
As responsabilidades organizacionais do comprador, pela avaliação e seleção de origem para identificar a capacidade do fornecedor, devem ser identificadas.

As medidas do comprador para avaliar e selecionar as fontes de aquisição devem ser documentadas e devem incluir um ou mais dos seguintes elementos:

1. Avaliação do histórico de fornecedor para providenciar um produto idêntico ou similar que corresponda satisfatoriamente ao uso atual. Essa avaliação deve refletir a capacidade atual.

2. Avaliação de registros atuais de controle de qualidade do fornecedor, apoiada por informações qualitativas e quantitativas documentadas que poderão ser avaliadas objetivamente.

3. As avaliações da capacidade técnica e da qualidade do fornecedor são determinadas por uma avaliação direta das instalações e sua equipe, e aplicação do programa de controle de qualidade do fornecedor.

Os resultados da avaliação e seleção da fonte de aquisição devem ser documentados.

\section{- Avaliação da Proposta/Licitação}

O processo de proposta/licitação deve incluir uma determinação da extensão da conformidade com os requerimentos dos documentos de aquisição. Essa avaliação deve ser realizada por indivíduos ou organizações selecionados que sejam tecnicamente qualificados em práticas e conceitos de garantia da qualidade.

A avaliação deve incluir os seguintes temas, conforme aplicáveis ao tipo de aquisição:

1. Considerações técnicas.

2. Requerimentos do programa de garantia da qualidade.

3. Fornecedor de pessoal.

4. Capacidade de produção do fornecedor.

5. Histórico de desempenho do fornecedor.

6. Alternativas.

7. Exceções. 
Antes da escolha do contrato, o comprador deve resolver, ou se comprometer a tal, as condições inaceitáveis de qualidade identificadas durante a avaliação da proposta/licitação.

Quaisquer deficiências que afetem a qualidade deverão ser corrigidas antes do início do trabalho que afeta a qualidade.

O documento que descreve o SGQ do fornecedor deve ser aceito pelo comprador antes do início do trabalho.

\section{- Avaliação de Desempenho do Fornecedor}

O comprador de itens e serviços estabelece as medidas para realizar a interface com o fornecedor e verifica o desempenho considerado necessário pelo comprador. As medidas devem incluir:

1. Entendimento entre o comprador e o fornecedor com relação aos requisitos e especificações identificados nos documentos de aquisição.

2. Exigir que o fornecedor identifique técnicas de planejamento e processos a serem utilizados no cumprimento dos requisitos dos documentos de aquisição.

3. Rever documentos de fornecedores que estejam preparados ou processados durante 0 trabalho realizado, de forma a cumprir as exigências dos documentos de aquisição.

4. Identificar e processar as informações necessárias para mudanças.

5. Estabelecer o método a ser utilizado para documentar a troca de informações entre o comprador e o fornecedor.

6. Estabelecer o grau da vigilância e inspeção.

Avaliações de desempenho devem ser realizadas periodicamente em cada fornecedor para determinar a necessidade de auditorias adicionais. Essa avaliação deve ser documentada e baseada em:

1. Revisão de documentos e registros do fornecedor (ex.: certificados de conformidade, Certificado de Autorização da autoridade competente, Certificado de Sistema de Qualidade, avisos de não conformidades e ações corretivas, etc.).

2. Resultados das verificações anteriores de origem, auditorias, avaliações de gestão e inspeções recebidas, incluindo resultados de auditorias a partir de outras origens (ex.: outros clientes, CNEN, etc.). 
3. Experiência operacional com produtos idênticos ou similares fornecidos pelo mesmo fornecedor.

O grau das verificações, incluindo planejamento, deve ser uma função importante conforme a complexidade e quantidade de itens ou serviços que estejam sendo adquiridos e o desempenho da qualidade do fornecedor.

As atividades de verificação devem ser realizadas por pessoal qualificado atribuído para verificar, inspecionar, auditar ou agir como testemunha.

As verificações devem ser realizadas assim que possível e não eximem os fornecedores de suas responsabilidades quanto à verificação da realização da qualidade.

As verificações incluem: o uso de auditorias para avaliar o desempenho do fornecedor e a avaliação da documentação do comprador para auxiliar na determinação da eficácia do $S G Q$ do fornecedor. Esta documentação deve incluir a relacionada a fontes da vigilância e inspeções, auditorias, inspeções recebidas, não conformidades, disposições, renúncias e ações corretivas.

E na sequência, a terceira subseção 4.6.3 "Controle de Itens e Serviços Adquiridos":

4.6.3.1 Os itens e serviços adquiridos, a fim de assegurar a conformidade com os documentos de aquisição, devem estar sujeitos a um controle sob a forma de medidas tais como:

a) evidência objetiva da qualidade, fornecida pelos contratados:

b) inspeção e auditoria na fonte;

c) exame do produto na entrega.

4.6.3.2 Se exigido, amostras de material, conforme especificado, devem ser guardadas por determinado prazo em local combinado, bem como controladas para permitir exames posteriores.

4.6.3.3 A evidência documental de que os itens adquiridos estão em conformidade com os documentos de aquisição deve, antes da instalação ou uso, estar disponível no local da instalação e ser suficiente para demonstrar que todos os requisitos foram satisfeitos por esses itens.

4.6.3.4 A evidência documental, referida na subseção anterior, pode estar na forma de um certificado de conformidade que identifique os requisitos satisfeitos pelo item, contanto que a validade de tais certificados possa ser comprovada. (CNEN, 2000). 
O detalhamento realizado utilizando os itens correspondentes da regulação americana segue abaixo:

\section{- Aceitação de Itens ou Serviços}

Os fornecedores devem verificar se os itens ou serviços oferecidos cumprem com os requisitos nos documentos de aquisição do comprador antes de oferecerem os produtos ou serviços para aceitação.

Quando exigido por código, regulamento ou requerimento em documentos de aquisição, evidência documental de que os itens ou serviços estão em conformidade com os documentos de aquisição deve estar disponível nas instalações do comprador antes que o item seja instalado, ou antes que o serviço seja utilizado.

Métodos para aceitação de itens ou serviços fornecidos pelo fornecedor devem garantir que os itens ou serviços estejam em conformidade com os requisitos em documentos de aquisição do comprador e incluir um ou mais dos seguintes procedimentos, conforme apropriado para os itens ou serviços sendo adquiridos:

1. Avaliação do certificado de conformidade do fornecedor (itens e serviços relacionados).

2. Desempenho de um ou uma combinação de: verificação de origem, inspeção recebida, ou teste pós-instalação (itens e serviços relacionados).

3. Verificação técnica dos dados produzidos (somente serviços).

4. Fiscalização e/ou auditoria da atividade (apenas serviços).

5. Revisão de evidências objetivas (ex.: certificações e relatórios de teste) para o atendimento aos requerimentos de documentação de aquisição (apenas serviços).

O comprador deve aceitar os itens e serviços antes da instalação ou utilização.

- Certificado de Conformidade

Quando um certificado de conformidade for utilizado para aceitação de um item ou serviço relacionado: 
1. O certificado deve identificar 0 item ou serviço adquirido com o respectivo documento de contrato.

2. O certificado deve identificar os requerimentos de documentação de aquisição específicos referentes ao item ou serviço adquirido, como códigos, normas e outras especificações. Os requerimentos de documentação de aquisição identificados devem incluir todas as mudanças aprovadas, renúncias, ou modificações aplicáveis ao item ou serviço.

3. A certificação deve identificar quaisquer requerimentos de documentos de compra que tenham sido cumpridos, juntamente com uma explicação e os meios para resolver as não conformidades.

4. A certificação deve ser atestada por uma pessoa responsável pela função de controle de qualidade e cujas responsabilidades e cargo estejam descritos no SGQ do fornecedor.

5. O processo de certificação, incluindo os documentos de execução para preenchimento de certificado, bem como os documentos administrativos para análise e aprovação dos certificados, devem estar descritos na documentação do SGQ do comprador ou fornecedor.

6. Devem ser identificadas medidas para verificar a validade dos certificados e a eficácia do processo de certificação (isto é, por auditoria do fornecedor ou por inspeção independente ou teste do item). As verificações devem ser realizadas pelo comprador em intervalos proporcionais ao histórico de bom desempenho do fornecedor.

- Verificação de Origem

O comprador pode aceitar um item ou serviço via monitoramento, testemunha, ou pela observação de atividades realizadas pelo fornecedor. Este método de aceitação é chamado de verificação de origem.

A verificação de origem deve ser planejada e executada por indivíduos treinados e qualificados em práticas e conceitos de controle de qualidade, de acordo com procedimentos escritos para garantir a conformidade com os requerimentos de aquisição. Procedimentos aplicáveis ao método de aquisição devem assegurar: 
1. A especificação das características ou processos a serem testemunhados, inspecionados, ou verificados e o método de vigilância e grau de documentação necessária.

2. Auditorias, vigilância, ou inspeções que verifiquem a eficácia do SGQ do fornecedor $e$ as atividades de controle de qualidade, e garantam que o fornecedor esteja em conformidade com a garantia da qualidade e os requisitos técnicos.

A verificação de origem deve ser realizada para inspecionar, monitorar, testemunhar ou observar as atividades compatíveis com a fabricação, inspeções, exames ou testes planejados do fornecedor, bem como os embarques de itens em pontos pré-determinados e realizados em intervalos consistentes com a importância e complexidade de cada item.

A evidência documentada da aceitação de itens ou serviços verificados na origem deve ser fornecida para o destino de recebimento do item, tanto para o comprador como para o fornecedor.

- Inspeção de Recebimento

Quando houver inspeção de recebimento para aceitação de um item:

A inspeção deve considerar os resultados das verificações e auditorias de origem e o desempenho da qualidade demonstrado pelo fornecedor.

A inspeção deve ser realizada de acordo com seus relativos documentos.

A inspeção deve verificar por evidência objetiva recursos como: configuração adequada, identificação, características dimensionais, físicas e outras, proteção contra danos durante o transporte e limpeza.

A inspeção de recebimento deve ser coordenada com uma análise da documentação do fornecedor, quando os documentos de aquisição exigirem tal documentação antes da inspeção.

\section{- Teste Pós-Instalação}

Quando o teste pós-instalação for utilizado como método de aceitação, os requerimentos para o teste pós-instalação e a documentação de aceitação devem ser estabelecidos de comum acordo pelo comprador e pelo fornecedor. $\mathrm{O}$ teste deve estar de acordo com os requerimentos da seção "Controle de Testes". 
As páginas a seguir são a de "Inclusão de Aquisições" e a de "Consulta de Edição de Aquisições", utilizadas pelo executor; "Verificação de Aquisições", utilizada pelo verificador; e "Aprovação de Aquisições", que o gerente utilizará.

\subsubsection{Página Inclusão de Aquisições}

Itens a serem apresentados na página "Inclusão de Aquisições":

- Título "Inclusão de Aquisições";

- Nome do usuário e data / horário de acesso;

- Caixa de entrada "Aquisição";

- Caixa de entrada "Fornecedor";

- Caixa de entrada "Escopo";

- Caixa de entrada "Requisitos técnicos e de qualidade";

- Caixa de entrada "Requisitos de ensaios / testes / inspeção";

- Caixa de entrada "Inspeção e auditoria na fonte";

- Caixa de entrada "Outras exigências de Garantia da Qualidade";

- Caixa de entrada "Prazo de submissão";

- Caixa de entrada "Documentos da qualidade do Fornecedor";

- Caixa de entrada "Documentos de avaliação do produto";

- Botão "Salvar";

- Botão "Cancelar";

- Botão "Sair".

Operações elementares:

1) Digitar o nome da "Aquisição";

2) Digitar "Fornecedor";

3) Digitar "Escopo";

4) Digitar "Requisitos técnicos e de qualidade";

5) Digitar "Requisitos de ensaios / testes / inspeção";

6) Digitar "Documentos de inspeção ou auditoria na fonte";

7) Digitar "Outras exigências de Garantia da Qualidade";

8) Digitar "Prazo de submissão"; 
9) Digitar "Documentos de qualidade do Fornecedor";

10) Digitar "Documentos de avaliação do produto";

11) Clicar no botão "Salvar". O sistema grava os dados na tabela correspondente. Informativo é enviado para o Verificador, avisando sobre nova Aquisição.

O fluxograma correspondente encontra-se na Figura 09.

Figura 09 - Fluxograma "Inclusão de Aquisições"

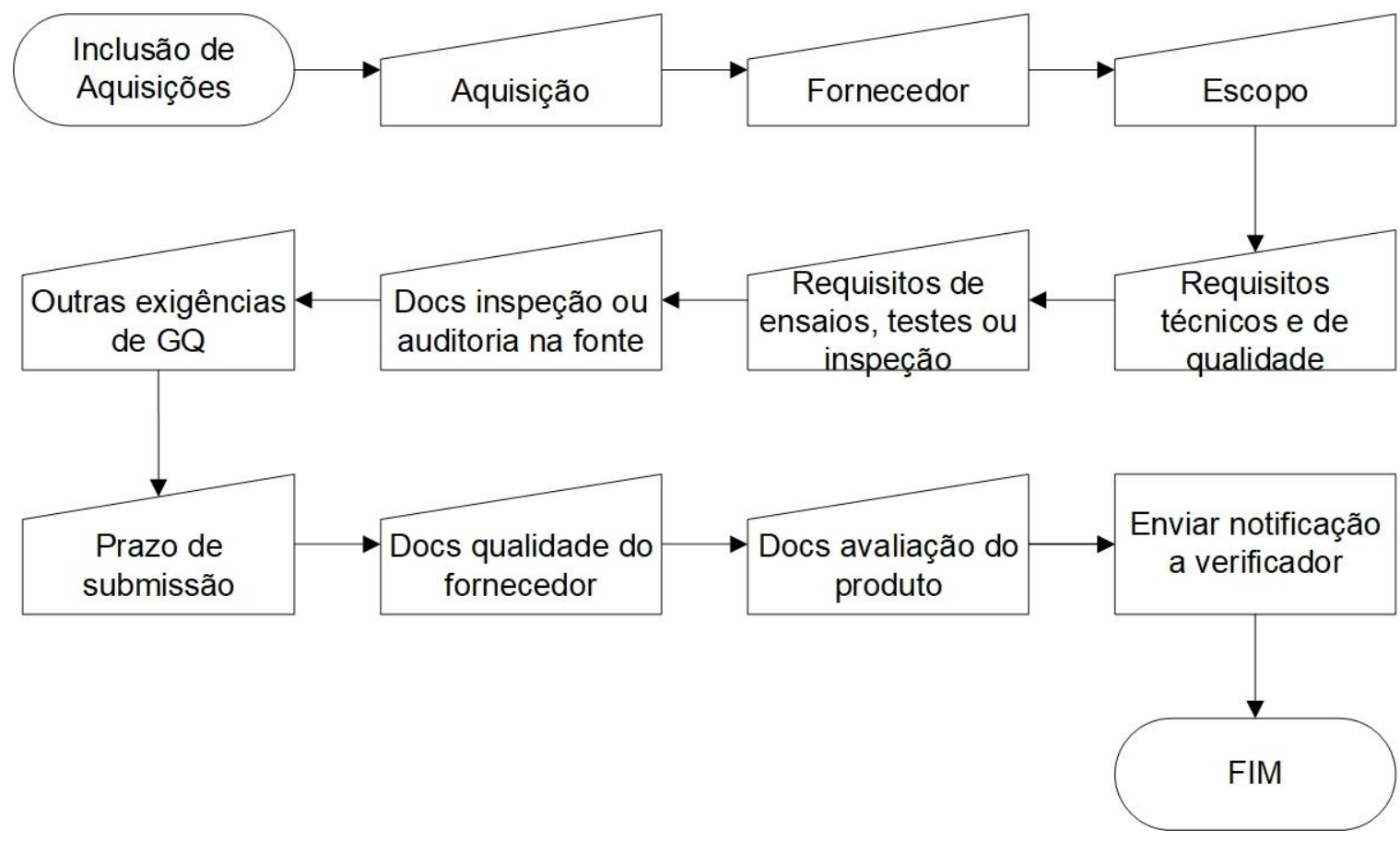

5.3.2 Página Consulta e Edição de Aquisições

Itens a serem apresentados na página "Consulta e Edição de Aquisições":

- Título "Consulta de Aquisições";

- Nome do usuário e data / horário de acesso;

- Botão "Pesquisar";

- Botão de escolha "Pesquisa por nome da aquisição, fornecedor ou escopo";

- Caixa de entrada "Dado a pesquisar";

- Caixa de entrada "Aquisição(ões) pesquisada(s)";

- Botão "Sair". 
Operações elementares:

1) Digitar uma palavra-chave correspondente à(s) aquisição(ões) a ser(em) buscada(s);

2) Utilizar o botão de escolha para selecionar o campo de pesquisa da palavrachave digitada: por nome de aquisição, fornecedor ou escopo da mesma. Clicar em "Pesquisar";

3) O sistema busca a palavra-chave no campo de pesquisa selecionado na tabela correspondente. Caso não encontre nenhum item, aparece a mensagem "Nenhum item encontrado.". Retornar ao início da página de Consulta de Aquisições.

4) $O(s)$ item(ns) encontrado(s) é(são) listado(s) na Caixa de entrada "Aquisição(ões) Pesquisada(s)" (até 5 itens; para itens excedentes, cria-se uma barra de rolagem vertical à direita da lista);

5) Caso desejado, clicar em um dos itens listados e clicar em "Modificar";

6) Ao clicar em "Modificar", o sistema verifica qual item pesquisado foi selecionado; caso nenhum o tenha, aparece a mensagem "Nenhum item selecionado.".

7) Caso haja um item selecionado, o sistema traz os dados nos mesmos campos da página "Inclusão de Aquisições", passíveis de modificações. O usuário modifica os valores de acordo e clica em "Salvar". O sistema atualiza a tabela. Retornar ao início da página de Consulta e Edição de Aquisições. É enviada ao verificador notificação de modificação de aquisições.

8) Clicar em "Sair". O sistema fecha.

O fluxograma correspondente encontra-se na Figura 10. 
Figura 10 - Fluxograma "Consulta e Edição de Aquisições"

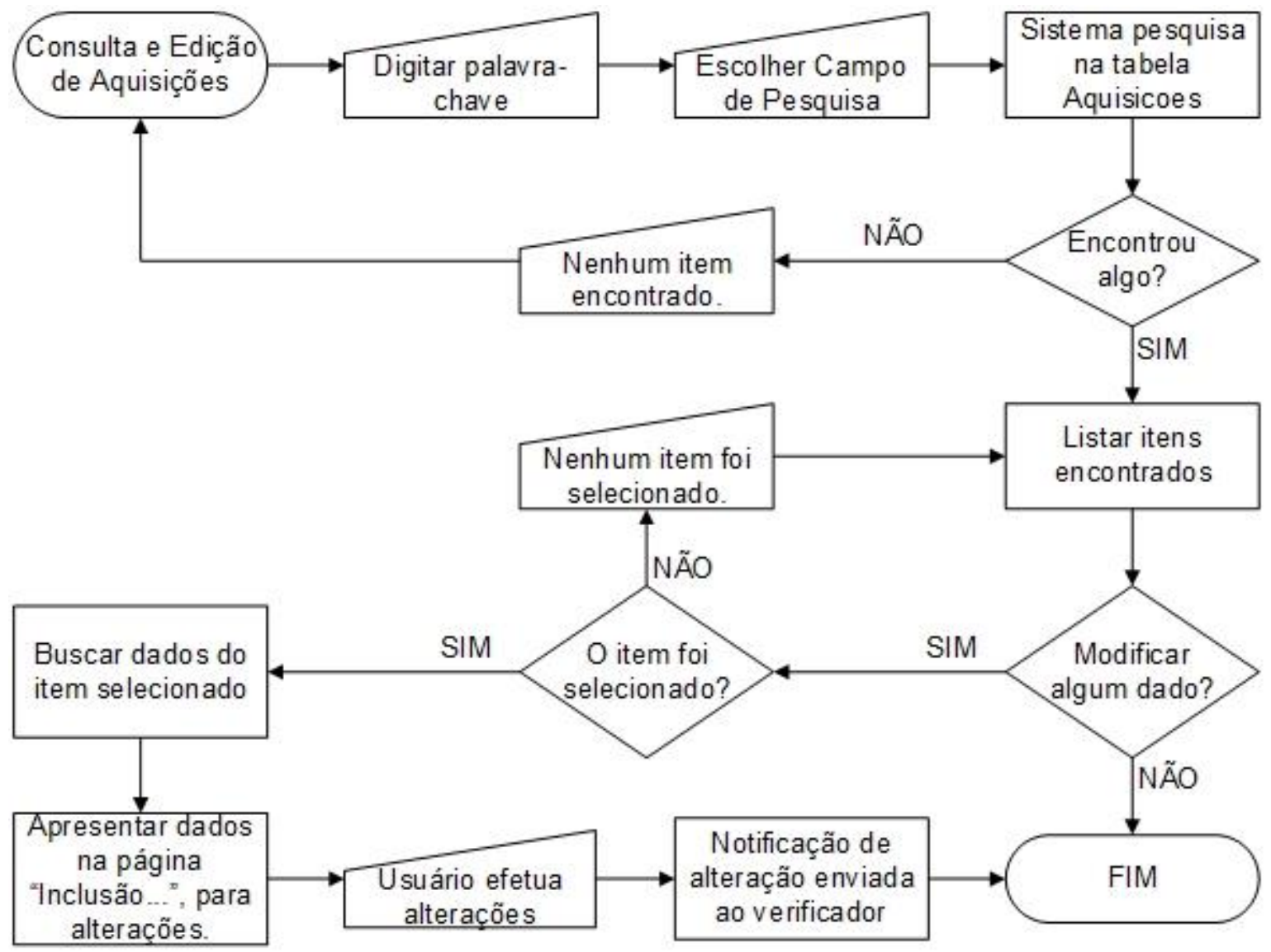

\subsubsection{Página Verificação de Aquisições}

Itens a serem apresentados na página "Verificação de Aquisições":

- Inicialmente, a página de Entrada;

- Depois, a página com o título "Verificação de Aquisições";

- Caixa de texto com lista de itens a serem verificados (até 3 ou 5);

- Botão "Aceito";

- Botão "Rejeitado";

- Botão "Cancelar";

- Botão "Sair";

- Caixa de texto "Item aceito?" - incluir botões "Sim" e "Não";

- Caixa de texto "Item rejeitado?" - incluir botões "Sim" e "Não".

Operações elementares: 
1) $O$ verificador recebeu uma notificação de inclusão de aquisições. Após ser autorizado via login e senha, ele abre a página "Verificação de Aquisições".

2) As aquisições incluídas aparecem na página. $O$ verificador seleciona o item e analisa os dados. Na sequência, ele clica no botão "Aceito" ou "Rejeitado".

3) Se o verificador clicar em "Aceito", a informação de "verificado" é registrada no banco de dados, uma mensagem informativa é enviada para o autor dos dados, e uma notificação é enviada ao responsável pela aprovação final.

4) Caso o verificador clique em "Rejeitado", ele digita o motivo pelo qual o item foi rejeitado, e depois clica em "Enviar". Tal informação é registrada no banco de dados, e uma notificação é enviada para o autor dos dados, para que este revise os mesmos.

O fluxograma correspondente encontra-se na Figura 11.

Figura 11 - Fluxograma "Verificação de Aquisições"

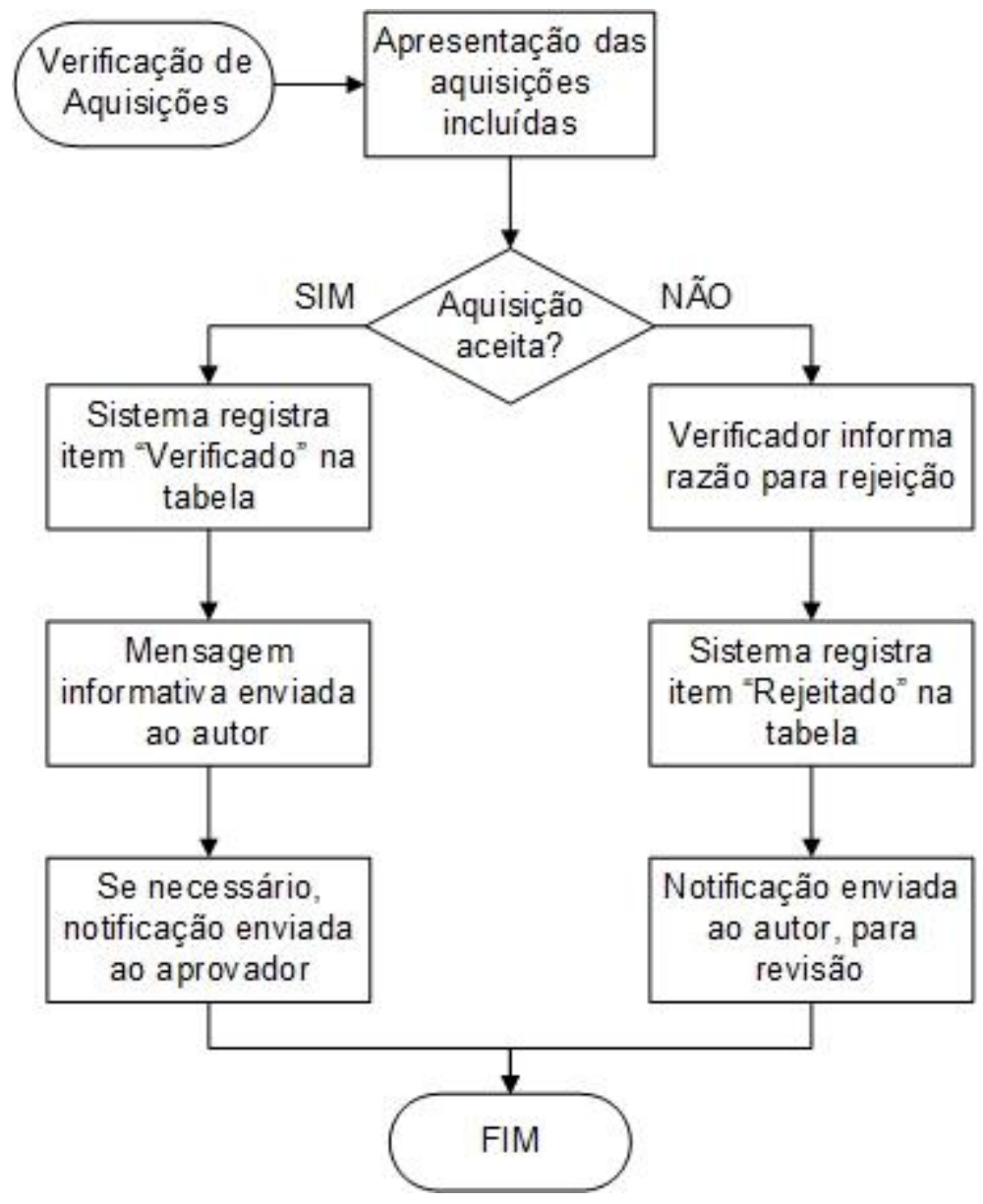


5.3.4 Página Aprovação de Aquisições

Itens a serem apresentados na página "Aprovação de Aquisições":

- Inicialmente, a página de Entrada;

- Depois, a página com o título "Aprovação de Aquisições";

- Caixa de texto com lista de itens a serem aprovados (até 5);

- Botão "Aprovado";

- Botão "Recusado";

- Botão "Cancelar";

- Botão "Sair";

- Caixa de texto "Item aprovado?" - incluir botões "Sim" e "Não";

- Caixa de texto "Item recusado?" - incluir botões "Sim" e "Não".

Operações elementares:

1) $O$ aprovador recebeu uma notificação de aquisições verificadas. Após ser autorizado via login e senha, ele abre a página "Aprovação de Aquisições".

2) Os itens verificados aparecem na página. $O$ aprovador seleciona $o$ item $e$ analisa os dados. Na sequência, ele clica no botão "Aprovado" ou "Recusado".

3) Se o aprovador clicar em "Aprovado", a informação de "aprovado" é registrada no banco de dados, e mensagens informativas da aprovação final são enviadas para o autor dos dados e o verificador.

4) Caso o aprovador clique em "Recusado", ele digita o motivo pelo qual o item foi recusado, e depois clica em "Enviar". Tal informação é registrada no banco de dados, e notificações são enviadas para o autor dos dados e para 0 verificador, para revisão.

O fluxograma correspondente encontra-se na Figura 12. 
Figura 12 - Fluxograma "Aprovação de Aquisições"

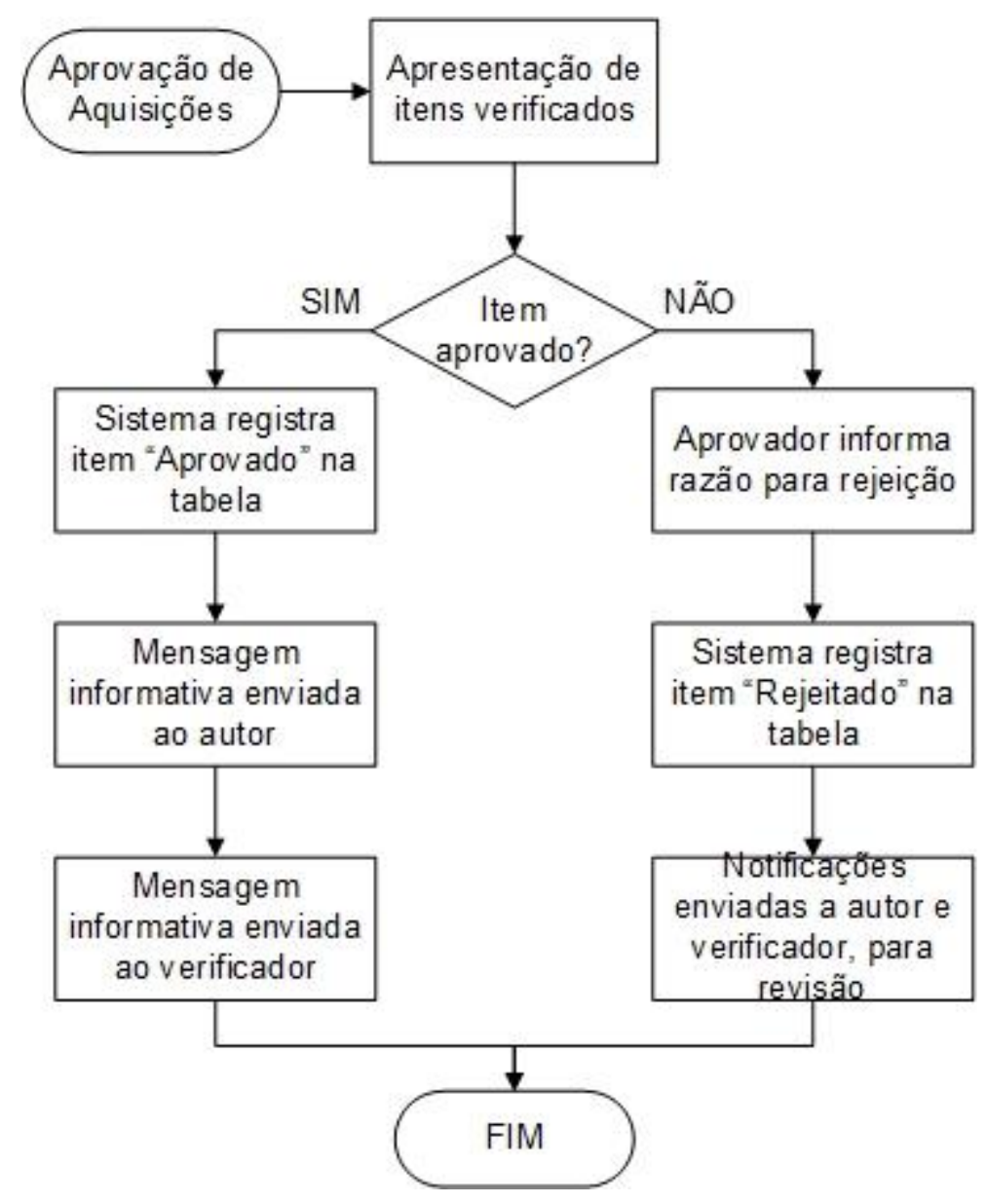

\subsection{Controle de Materiais}

Os requisitos da CNEN-NN-1.16 para este item estão especificados na seção 4.7 "Controle de Materiais". Esta seção está subdividida em duas subseções referentes a identificação, controle, manuseio, armazenagem e embarque de materiais. A seguir, segue a primeira subseção 4.7.1 "Identificação e Controle de Materiais, Peças e Componentes":

4.7.1.1 Devem ser estabelecidas medidas para a identificação e controle de itens, inclusive conjuntos parcialmente fabricados, durante toda a fabricação, montagem, instalação e uso, a fim de assegurar que a identificação do item seja mantida pelo número da corrida, número da peça, número de série ou outros meios apropriados, seja no item ou em registros rastreáveis ao item.

4.7.1.2 As medidas de identificação e controle devem ser planejadas para impedir o uso de materiais, peças $e$ componentes incorretos ou defeituosos. 
4.7.1.3 A documentação exigida para a identificação e controle de um item deve estar sempre disponível no local ao longo do processo de construção.

4.7.1.4 No que concerne aos meios para manter a identificação do item, devem ser obedecidos os seguintes princípios:

a) usar a identificação física ao máximo possível;

b) se a identificação física for impraticável ou insuficiente, empregar a separação física, o controle através de procedimentos ou outro meio apropriado;

c) se for empregada a identificação por marcação, que esta seja clara, inequívoca e indelével e aplicada de maneira a não afetar o funcionamento do item, evitando-se que fique encoberta por tratamento ou revestimento de superfície, a menos que seja previamente substituída por outro meio de identificação. (CNEN, 2000).

O detalhamento realizado utilizando os itens correspondentes da regulação americana segue abaixo:

- Identificação

A identificação deve estar anexada aos itens ou em documentos rastreáveis aos itens. Os itens devem ser identificados a partir do momento da fabricação, ou recebimento, até e incluindo a instalação ou utilização final (descarte).

A identificação deve relacionar um item a um projeto aplicável ou a outro documento específico pertinente. A correta identificação de itens deve ser verificada e documentada antes da liberação para fabricação, montagem, transporte ou instalação.

- Identificações Físicas

Métodos de identificação de itens devem incluir ao máximo possível o uso de identificações físicas. Caso estas sejam impraticáveis ou insuficientes, outros meios adequados devem ser empregados (ex.: separação física, rótulos ou etiquetas presas aos contêineres ou controle processual).

As identificações físicas, quando utilizadas, devem ser aplicadas utilizando materiais e métodos que forneçam uma identificação clara e legível; não afetar negativamente a função ou o tempo de vida do item; ser transferidas para cada parte de um item identificado, quando o item for dividido; e não ser 
eliminadas ou ocultas por tratamentos de superfície, revestimentos, ou após a instalação, a menos que substituídas por outros meios de identificação.

\section{- Requisitos Condicionais}

O controle de materiais deve atender aos seguintes requisitos, conforme o caso:

Se os códigos, normas ou especificações incluem requisitos específicos de identificação ou rastreabilidade (ex.: identificação ou rastreabilidade do item para uma especificação aplicável e linha de produto; lote, peça ou número de série; inspeção específica, teste ou outros registros), o programa deve ser projetado para fornecer o controle de tais identificações e rastreabilidades.

Se os códigos ou normas não incluem requisitos de identificação ou de rastreabilidade específicos, especificações devem fornecer os métodos de identificação e rastreabilidade apropriados ao item.

Caso os itens, incluindo produtos de consumo, possuam validade (de prateleira), vida útil, ou ciclos de operação, o uso deve ser controlado para:

1. Identificá-los de forma exclusiva.

2. Estabelecer registros que identifiquem validade, vida útil, e/ou ciclos de operação restantes.

3. Impedir a utilização desses itens, inclusive produtos de consumo, que tenham ultrapassado sua validade, vida útil, ou ciclos de operação.

Se o armazenamento do item for necessário, métodos devem ser estabelecidos para o controle da identificação do item que seja proporcional à duração planejada e condições de armazenamento. Esses métodos devem garantir, conforme o caso:

1. A manutenção ou substituição de marcas e etiquetas de identificação danificadas durante manuseio ou envelhecimento.

2. Proteção na identificação de itens sujeitos a deterioração excessiva resultante da exposição ambiental ou condições adversas de armazenamento.

3. Atualização de registros de programas existentes. 
Em seguida, a segunda subseção 4.7.2 "Manuseio, Armazenagem e Embarque":

4.7.2.1 Devem ser estabelecidas e documentadas medidas para controlar o manuseio, armazenagem e embarque, incluindo limpeza, embalagem e preservação de materiais e equipamentos, de acordo com instruções, procedimentos ou desenhos, a fim de evitar avarias, deterioração ou perdas.

4.7.2.2 Devem ser utilizados procedimentos específicos para itens sensíveis, críticos e deterioráveis, especificando-se, quando aplicáveis, invólucros, revestimentos, equipamentos de manuseio e/ou ambientes protetores especiais, cuja existência precisa ser verificada. (CNEN, 2000).

O detalhamento realizado utilizando os itens correspondentes da regulação americana está abaixo:

- Requisitos Gerais

Manuseio, armazenamento, limpeza, embalagem, transporte e preservação de itens deverão ser realizados de acordo com o trabalho estabelecido e inspeção na implementação de documentos, instruções de envio ou outros documentos especificados.

Se necessário, para artigos críticos, sensíveis, perecíveis ou de alto valor, devem ser elaborados e utilizados documentos específicos de implementação para manipulação, armazenamento, limpeza, embalagem, transporte e preservação.

- Equipamentos especiais, ferramentas e ambientes

Se necessário para itens específicos, equipamentos especiais devem ser especificados e fornecidos (por exemplo, recipientes, amortecedores e acelerômetros), bem como ambientes de proteção especiais (isto é, atmosfera de gás inerte e níveis específicos de umidade e níveis de temperatura).

Se forem utilizados equipamentos e ambientes especiais, devem ser tomadas providências para sua verificação.

As ferramentas e equipamentos de manipulação especiais devem ser utilizados e controlados, conforme necessário, para garantir um manuseio seguro e adequado. 
As ferramentas e equipamentos de manipulação especiais devem ser inspecionados e testados em intervalos de tempo especificados e de acordo com documentos de implementação para garantir que as ferramentas e o equipamento sejam adequadamente mantidos.

Os operadores de equipamentos especiais de movimentação e elevação devem ser experientes ou treinados para utilizar o equipamento.

\section{- Marcação e rotulagem}

Devem ser estabelecidas medidas para a marcação e rotulagem da embalagem, transporte, manuseio e armazenamento de itens, conforme necessário, para identificar, manter e preservar adequadamente o item.

As marcas e os rótulos devem indicar a presença de ambientes especiais ou a necessidade de controles especiais, se necessário.

As páginas a seguir são a de "Inclusão de Materiais" e a de "Consulta de Edição de Materiais", utilizadas pelo executor; "Verificação de Materiais", utilizada pelo verificador; e "Aprovação de Materiais”, utilizada pelo gerente.

\subsubsection{Página Inclusão de Materiais}

Itens a serem apresentados na página "Inclusão de Materiais":

- Título "Inclusão de Materiais";

- Nome do usuário e data / horário de acesso;

- Caixa de entrada "Nome do Item";

- Caixa de entrada "Forma de identificação";

- Caixa de entrada "Departamento";

- Caixa de entrada "Escopo";

- Caixa de opção "Em construção ou finalizado?";

- Caixa de entrada "Documentação e sua localização";

- Caixa de entrada "Procedimentos Específicos (item deteriorável / sensível / crítico / etc.)";

- Botão "Salvar";

- Botão "Cancelar";

- Botão "Sair". 
Operações elementares:

1) Digitar "Nome do item";

2) Digitar "Forma de identificação";

3) Digitar "Departamento";

4) Digitar "Escopo";

5) Selecionar "Em construção" ou "Finalizado";

6) Digitar "Documentação e sua localização";

7) Digitar "Procedimentos Específicos (item deteriorável / sensível / crítico / etc.)";

8) Clicar no botão "Salvar". O sistema grava os dados na tabela correspondente. Informativo é enviado para o Verificador, avisando sobre novo registro de Material.

O fluxograma correspondente encontra-se na Figura 13.

Figura 13 - Fluxograma "Inclusão de Materiais"

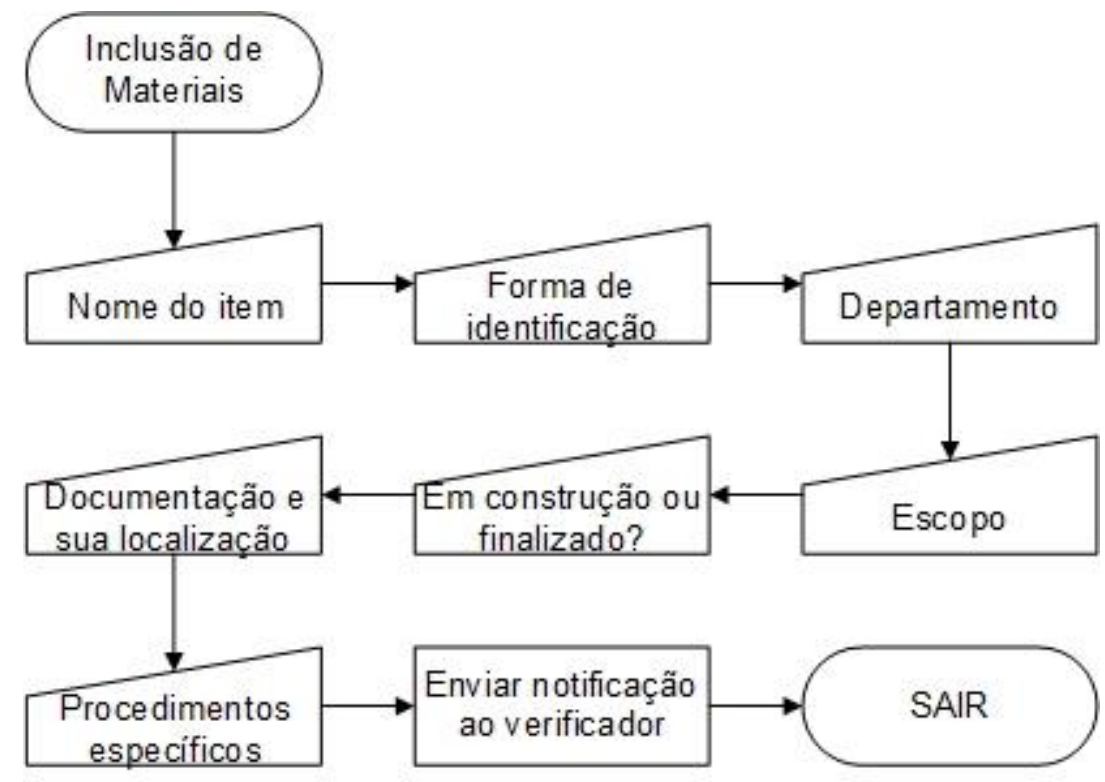

5.4.2 Página Consulta e Edição de Materiais

Itens a serem apresentados na página "Consulta e Edição de Materiais":

- Título "Consulta e Edição de Materiais";

- Nome do usuário e data / horário de acesso; 
- Botão "Pesquisar";

- Botão de escolha "Pesquisa por nome do item, departamento ou escopo";

- Caixa de entrada "Dado a pesquisar";

- Caixa de entrada "Documento(s) pesquisado(s)";

- Botão "Modificar";

- Botão "Sair".

Operações elementares:

1) Digitar uma palavra-chave correspondente ao(s) material(ais) a ser(em) buscado(s);

2) Utilizar o botão de escolha para selecionar o campo de pesquisa a palavrachave digitada: por nome do item, departamento ou escopo. Clicar em "Pesquisar";

3) O sistema busca a palavra-chave no campo de pesquisa selecionado na tabela correspondente. Caso não encontre nenhum item, aparece a mensagem "Nenhum item encontrado.". Retornar ao início da página "Consulta e Edição de Materiais".

4) $\mathrm{O}(\mathrm{s})$ item(ns) encontrado(s) é(são) listado(s) na Caixa de entrada "Material(ais) Pesquisado(s)" (até 5 itens; para itens excedentes, cria-se uma barra de rolagem vertical à direita da lista);

5) Caso desejado, clicar em um dos itens listados e clicar em "Modificar";

6) Ao clicar em "Modificar", o sistema verifica qual item pesquisado foi selecionado; caso nenhum o tenha, aparece a mensagem "Nenhum item selecionado.".

7) Caso haja um item selecionado, o sistema traz os dados nos mesmos campos da página "Inclusão de Materiais", passíveis de modificações. O usuário modifica os valores de acordo e clica em "Salvar". O sistema atualiza a tabela. Retornar ao início da página "Consulta e Edição de Materiais". É enviada ao verificador notificação de modificação de materiais.

8) Clicar em "Sair". O sistema fecha. 
Figura 14 - Fluxograma "Consulta e Edição de Materiais"

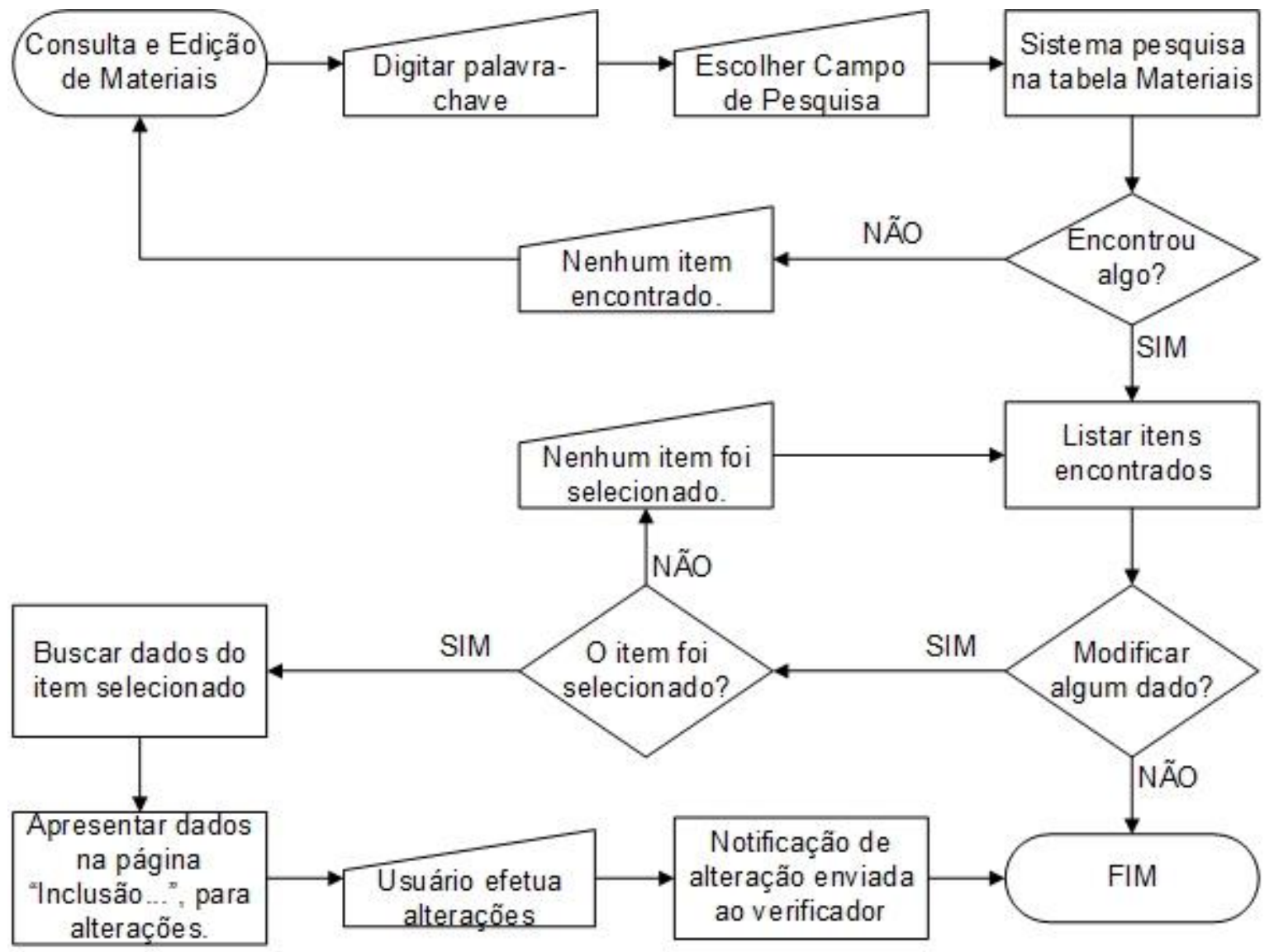

\subsubsection{Página Verificação de Materiais}

Itens a serem apresentados na página "Verificação de Materiais":

- Inicialmente, a página de Entrada;

- Depois, a página com o título "Verificação de Materiais";

- Caixa de texto com lista de itens a serem verificados (até 3 ou 5);

- Botão "Aceito";

- Botão "Rejeitado";

- Botão "Cancelar";

- Botão "Sair";

- Caixa de texto "Item aceito?" - incluir botões "Sim" e "Não";

- Caixa de texto "Item rejeitado?" - incluir botões "Sim" e "Não".

Operações elementares: 
1) $O$ verificador recebeu uma notificação de inclusão de materiais. Após ser autorizado via login e senha, ele abre a página "Verificação de Materiais".

2) Os materiais incluídos aparecem na página. O verificador seleciona o item e analisa os dados. Na sequência, ele clica no botão "Aceito" ou "Rejeitado".

3) Se o verificador clicar em "Aceito", a informação de "verificado" é registrada no banco de dados, uma mensagem informativa é enviada para o autor dos dados, e uma notificação é enviada ao responsável pela aprovação final.

4) Caso o verificador clique em "Rejeitado", ele digita o motivo pelo qual o item foi rejeitado, e depois clica em "Enviar". Tal informação é registrada no banco de dados, e uma notificação é enviada para o autor dos dados, para que este revise os mesmos.

O fluxograma correspondente encontra-se na Figura 15.

Figura 15 - Fluxograma "Verificação de Materiais"

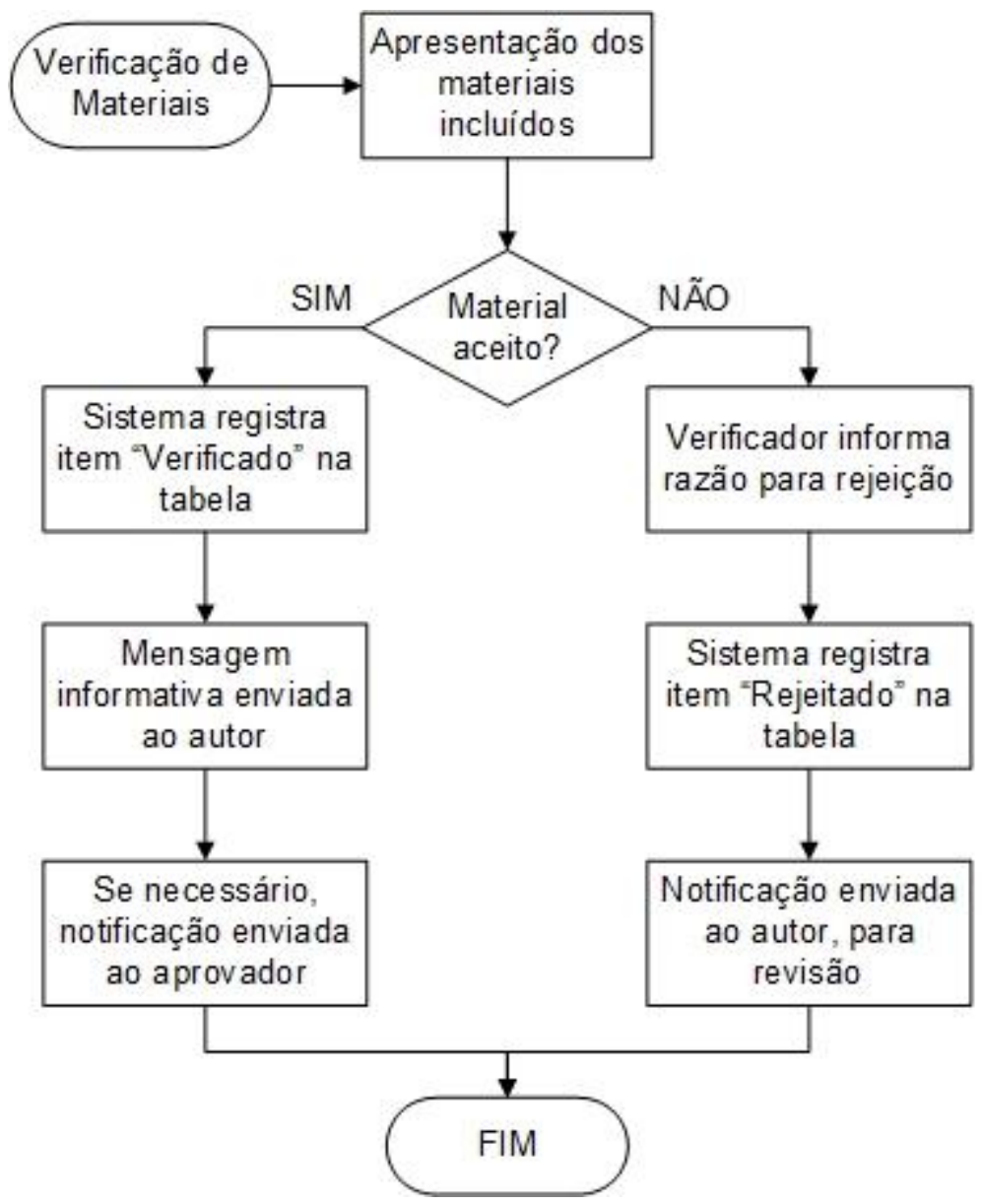




\subsubsection{Página Aprovação de Materiais}

Itens a serem apresentados na página "Aprovação de Materiais":

- Inicialmente, a página de Entrada;

- Depois, a página com o título "Aprovação de Materiais";

- Caixa de texto com lista de itens a serem aprovados (até 3 ou 5);

- Botão "Aprovado";

- Botão "Recusado";

- Botão "Cancelar";

- Botão "Sair";

- Caixa de texto "Item aprovado?" - incluir botões "Sim" e "Não";

- Caixa de texto "Item recusado?" - incluir botões "Sim" e "Não".

Operações elementares:

1) O aprovador recebeu uma notificação de materiais verificados. Após ser autorizado via login e senha, ele abre a página "Aprovação de Materiais".

2) Os itens verificados aparecem na página. $O$ aprovador seleciona $o$ item $e$ analisa os dados. Na sequência, ele clica no botão "Aprovado" ou "Recusado".

3) Se o aprovador clicar em "Aprovado", a informação de "aprovado" é registrada no banco de dados, e mensagens informativas da aprovação final são enviadas para o autor dos dados e o verificador.

4) Caso o aprovador clique em "Recusado", ele digita o motivo pelo qual o item foi recusado, e depois clica em "Enviar". Tal informação é registrada no banco de dados, e notificações são enviadas para o autor dos dados e para o verificador, para revisão.

O fluxograma correspondente encontra-se na Figura 16. 
Figura 16 - Fluxograma "Aprovação de Materiais"

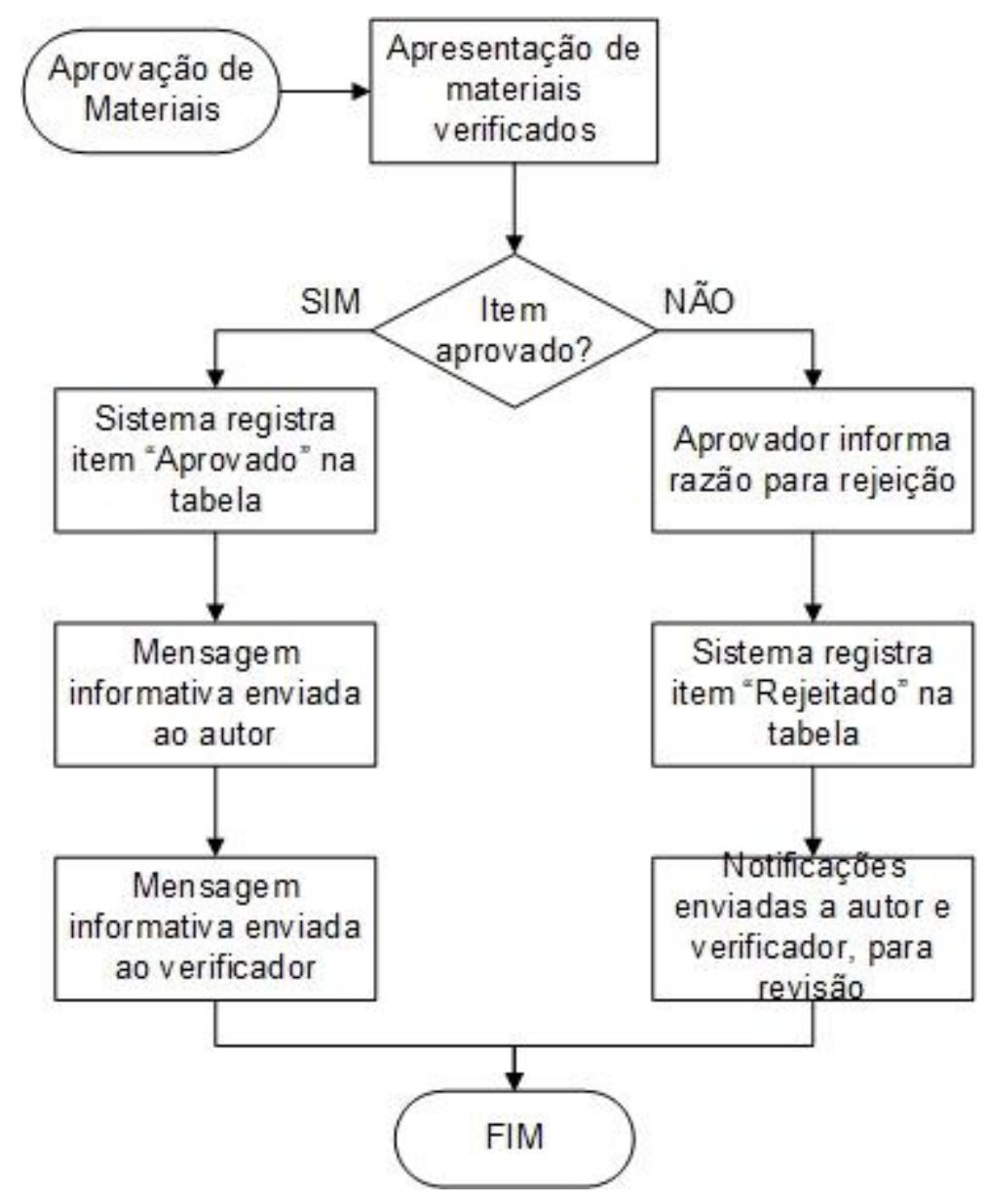

\subsection{Controle de Processos}

Os requisitos da CNEN-NN-1.16 para este item estão especificados na seção 4.8 "Controle de Processos". Esta seção não possui subseções. A seguir, segue a seção 4.8 "Controle de Processos":

4.8.1 Os processos que influem na qualidade, usados na construção, fabricação, testes, comissionamento e operação da instalação, nos quais a qualidade exigida não possa ser assegurada apenas pela inspeção dos itens, devem ser controlados de acordo com requisitos especificados. Tais processos incluem, entre outros, soldagem, fundição, forjamento tratamento térmico, eletrodeposição, proteção contra corrosão, ensaios não destrutivos, análise química e ensaios mecânicos e de corrosão.

4.8.2 Quando requerido por exigências da CNEN, normas, códigos, especificações ou critérios aplicáveis, devem ser estabelecidas e documentadas medidas para assegurar que os processos referidos em 4.8.1 sejam efetuados por 
pessoal qualificado, utilizando equipamentos e procedimentos qualificados.

4.8.3 No caso de processos não abrangidos pelas normas existentes ou em que as exigências de qualidade excedam às dessa normalização, devem ser definidas as qualificações necessárias de pessoal, procedimentos ou equipamentos. (CNEN, 2000).

O detalhamento realizado utilizando os itens correspondentes da regulação americana segue abaixo.

- Controle de Processos Especiais

Processos que afetam a qualidade de itens ou serviços devem ser controlados. Processos especiais que verificam a qualidade, tais como solda, tratamento térmico, limpeza química e exame não destrutivo devem ser controlados e realizados por pessoal qualificado, utilizando procedimentos qualificados de acordo com os códigos, normas, especificações, critérios e outros requisitos vigentes.

\section{- Processos Especiais}

Para os processos especiais não incluídos nos códigos e normas existentes, ou em que os requisitos de qualidade especificados para um item sejam superiores aos dos códigos ou normas existentes, tais requisitos necessários para a qualificação de pessoal, procedimentos e equipamentos devem ser especificados ou referenciados nos documentos.

Processos que sejam controlados como especiais devem atender aos seguintes critérios:

1. Os resultados devem ser altamente dependentes do controle de processo; ou

2. Os resultados devem ser altamente dependentes da habilidade do operador; e

3. A qualidade dos resultados não pode ser prontamente determinada por inspeção ou teste do produto. 
- Pessoal, Implementação de Documentos, Qualificações de Equipamentos

Devem ser utilizados documentos de aplicações para garantir que os parâmetros de processos sejam controlados e que as condições ambientais específicas sejam mantidas. Processos especiais de aplicação dos documentos devem incluir ou fazer referência a:

1. Responsabilidades organizacionais, incluindo indivíduos ou equipes treinadas e qualificadas em práticas e conceitos de $G Q$, para a qualificação de processos especiais em equipamentos e pessoal.

2. Registros a serem mantidos para cada método de processo especial.

3. Disposições relativas à evidência de registros de realização aceitável de processos especiais utilizando procedimentos qualificados, equipamentos e pessoal.

4. Requisitos de qualificação de pessoal, documentos de aplicações, e equipamentos que cumpram os requisitos especificados. Certificados de qualificação devem delinear claramente os processos específicos que os funcionários sejam qualificados para executar e os critérios utilizados para qualificar o pessoal em cada processo.

5. Condições que sejam necessárias para a realização de processos especiais devem ser incluídas na aplicação das normas documentadas. Tais condições incluem: equipamento adequado, parâmetros controlados do processo, requisitos de calibração, e rastreabilidade entre o item e o indivíduo que executa o processo especial.

6. Requisitos de códigos aplicáveis, normas e especificações, incluindo critérios de aceitação para processos especiais, devem ser referenciados ou especificados na aplicação dos documentos.

\section{- Qualificação e Certificação de Pessoal em Testes Não Destrutivos}

Testes não destrutivos incluem: radiografia, partículas magnéticas, ultrassom, líquido penetrante, corrente de Foucault, radiografia de nêutrons, emissão acústica e teste de vazamento.

O pessoal que realizar estes testes não destrutivos deve ser qualificado e certificado de acordo com a regulamentação vigente. A qualificação e certificação devem incluir uma demonstração de desempenho como parte do exame prático. 
Devem ser estabelecidos documentos para o controle e administração de pessoal em testes não destrutivos: treinamento e certificação.

As páginas a seguir são a de "Inclusão de Processos" e a de "Consulta de Edição de Processos", utilizadas pelo executor; "Verificação de Processos", que será utilizada pelo verificador; e "Aprovação de Processos", utilizada pelo gerente.

\subsubsection{Página Inclusão de Processos}

Itens a serem apresentados na página "Inclusão de Processos":

- Título "Inclusão de Processos";

- Nome do usuário e data / horário de acesso;

- Caixa de entrada "Tipo de processo";

- Caixa de entrada "Instalação de realização";

- Caixa de entrada "Pessoal a realizar o processo";

- Caixa de entrada "Data de realização";

- Caixa de entrada "Exigências e normas - aplicáveis a processo, pessoal e equipamento";

- Caixa de entrada "Equipamentos (incluir dados de calibração ou outros, que atestem a qualidade)";

- Botão "Salvar";

- Botão "Cancelar";

- Botão "Sair".

Operações elementares:

1) Digitar "Tipo de processo";

2) Digitar "Instalação de realização";

3) Digitar "Pessoal a realizar o processo";

4) Digitar "Data de realização";

5) Digitar "Exigências e normas - aplicáveis a processo, pessoal e equipamento";

6) Digitar "Equipamentos (incluir dados de calibração ou outros, que atestem a qualidade)"; 
7) Clicar no botão "Salvar". O sistema grava os dados na tabela correspondente. Informativo é enviado para o Verificador, avisando sobre a inclusão de novo Processo.

O fluxograma correspondente encontra-se na Figura 17.

Figura 17 - Fluxograma "Inclusão de Processos"

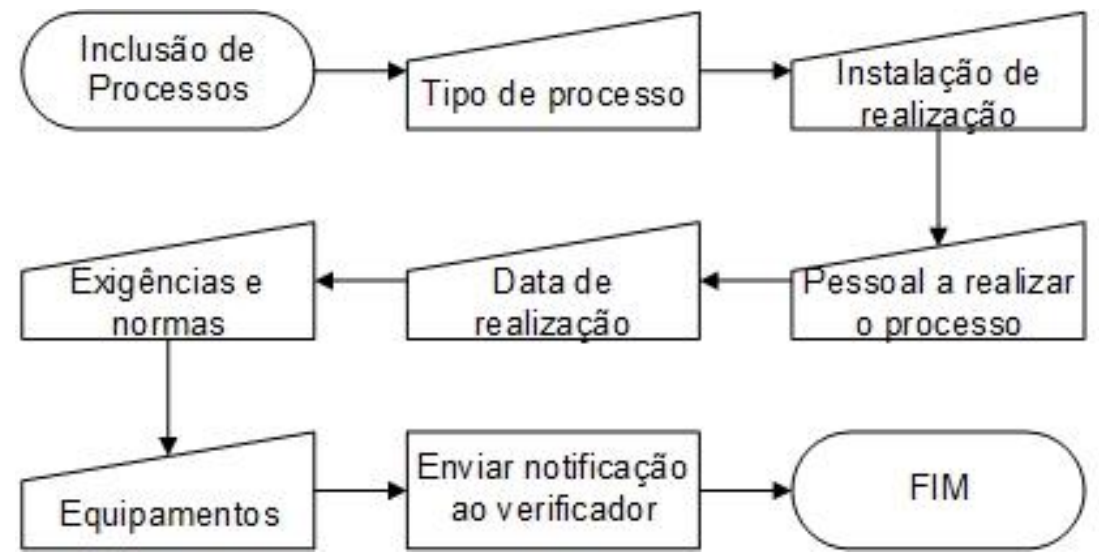

5.5.2 Página Consulta e Edição de Processos

Itens a serem apresentados na página "Consulta e Edição de Processos":

- Título "Consulta e Edição de Processos";

- Nome do usuário e data / horário de acesso;

- Botão "Pesquisar";

- Botão de escolha "Pesquisa por Tipo de processo, Instalação de realização, Pessoal a realizar o processo e Data de realização";

- Caixa de entrada "Dado a pesquisar";

- Caixa de entrada "Processo(s) pesquisado(s)";

- Botão "Modificar";

- Botão "Sair".

Operações elementares:

1) Digitar uma palavra-chave correspondente ao(s) processo(s) a ser(em) buscado(s); 
2) Utilizar o botão de escolha para selecionar no campo de pesquisa a palavrachave digitada: por Tipo de processo, Instalação de realização, Pessoal a realizar o processo e Data de realização. Clicar em "Pesquisar";

3) O sistema busca a palavra-chave no campo de pesquisa selecionado na tabela correspondente. Caso não encontre nenhum item, aparece a mensagem "Nenhum item encontrado.". Retornar ao início da página "Consulta e Edição de Processos".

4) $\mathrm{O}(\mathrm{s})$ item(ns) encontrado(s) é(são) listado(s) na Caixa de entrada "Processo(s) Pesquisado(s)" (até 5 itens; para itens excedentes, cria-se uma barra de rolagem vertical à direita da lista);

5) Caso desejado, clicar em um dos itens listados e clicar em "Modificar";

6) Ao clicar em "Modificar", o sistema verifica qual item pesquisado foi selecionado; caso nenhum o tenha, aparece a mensagem "Nenhum item selecionado.".

7) Caso haja um item selecionado, o sistema traz os dados nos mesmos campos da página "Inclusão de Processos", passíveis de modificações. O usuário modifica os valores de acordo e clica em "Salvar". O sistema atualiza a tabela. Retornar ao início da página "Consulta e Edição de Processos". É enviada ao verificador notificação de modificação de processos.

8) Clicar em "Sair". O sistema fecha.

O fluxograma correspondente encontra-se na Figura 18. 
Figura 18 - Fluxograma "Consulta e Edição de Processos"

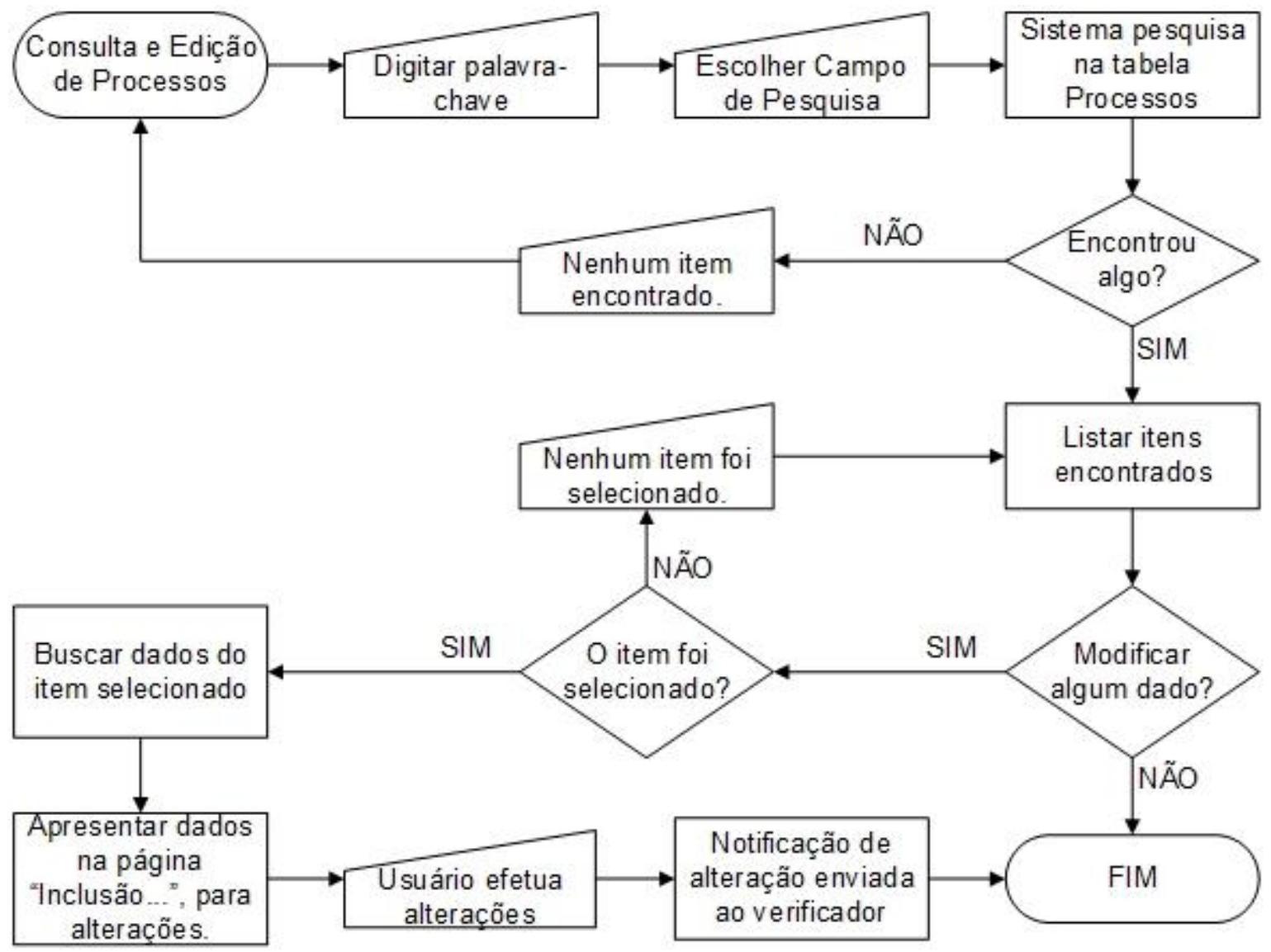

\subsubsection{Página Verificação de Processos}

Itens a serem apresentados na página "Verificação de Processos":

- Inicialmente, a página de Entrada;

- Depois, a página com o título "Verificação de Processos";

- Caixa de texto com lista de itens a serem verificados (até 3 ou 5);

- Botão "Aceito";

- Botão "Rejeitado";

- Botão "Cancelar";

- Botão "Sair";

- Caixa de texto "Item aceito?" - incluir botões "Sim" e "Não";

- Caixa de texto "Item rejeitado?" - incluir botões "Sim" e "Não".

Operações elementares: 
1) $O$ verificador recebeu uma notificação de inclusão de processos. Após ser autorizado via login e senha, ele abre a página "Verificação de Processos".

2) Os processos incluídos aparecem na página. O verificador seleciona o item e analisa os dados. Na sequência, ele clica no botão "Aceito" ou "Rejeitado".

3) Se o verificador clicar em "Aceito", a informação de "verificado" é registrada no banco de dados, uma mensagem informativa é enviada para o autor dos dados, e uma notificação é enviada ao responsável pela aprovação final.

4) Caso o verificador clique em "Rejeitado", ele digita o motivo pelo qual o item foi rejeitado, e depois clica em "Enviar". Tal informação é registrada no banco de dados, e uma notificação é enviada para o autor dos dados, para que este revise os mesmos.

O fluxograma correspondente encontra-se na Figura 19.

Figura 19 - Fluxograma "Verificação de Processos"

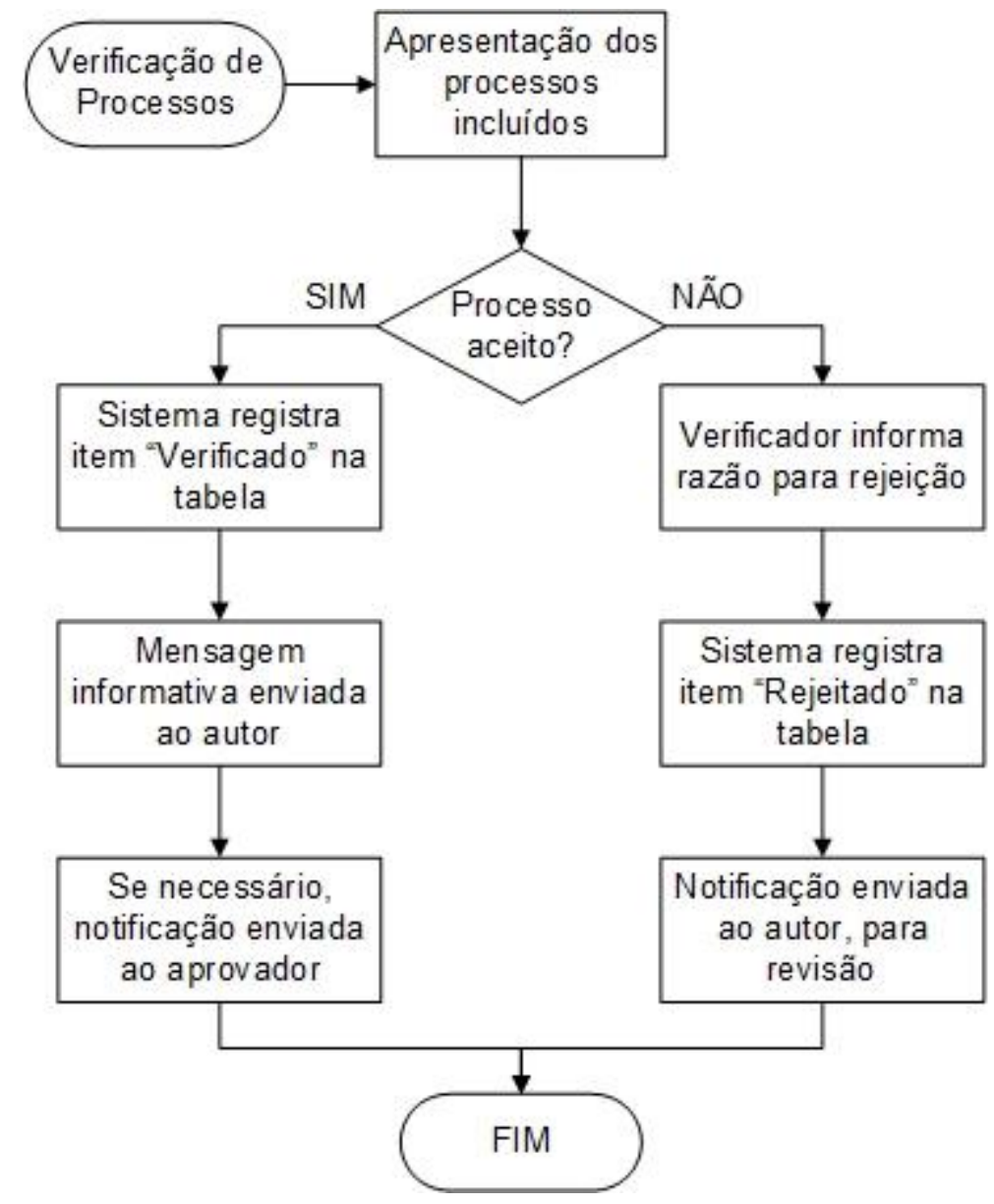




\subsubsection{Página Aprovação de Processos}

Itens a serem apresentados na página "Aprovação de Processos":

- Inicialmente, a página de Entrada;

- Depois, a página com o título "Aprovação de Processos";

- Caixa de texto com lista de itens a serem aprovados (até 3 ou 5);

- Botão "Aprovado";

- Botão "Recusado";

- Botão "Cancelar";

- Botão "Sair";

- Caixa de texto "Item aprovado?" - incluir botões "Sim" e "Não";

- Caixa de texto "Item recusado?" - incluir botões "Sim" e "Não".

Operações elementares:

1) O aprovador recebeu uma notificação de processos verificados. Após ser autorizado via login e senha, ele abre a página "Aprovação de Processos".

2) Os processos verificados aparecem na página. $O$ aprovador seleciona $o$ item $e$ analisa os dados. Na sequência, ele clica no botão "Aprovado" ou "Recusado".

3) Se o aprovador clicar em "Aprovado", a informação de "aprovado" é registrada no banco de dados, e mensagens informativas da aprovação final são enviadas para o autor dos dados e o verificador.

4) Caso o aprovador clique em "Recusado", ele digita o motivo pelo qual o item foi recusado, e depois clica em "Enviar". Tal informação é registrada no banco de dados, e notificações são enviadas para o autor dos dados e para o verificador, para revisão.

O fluxograma correspondente encontra-se na Figura 20. 
Figura 20 - Fluxograma "Aprovação de Processos"

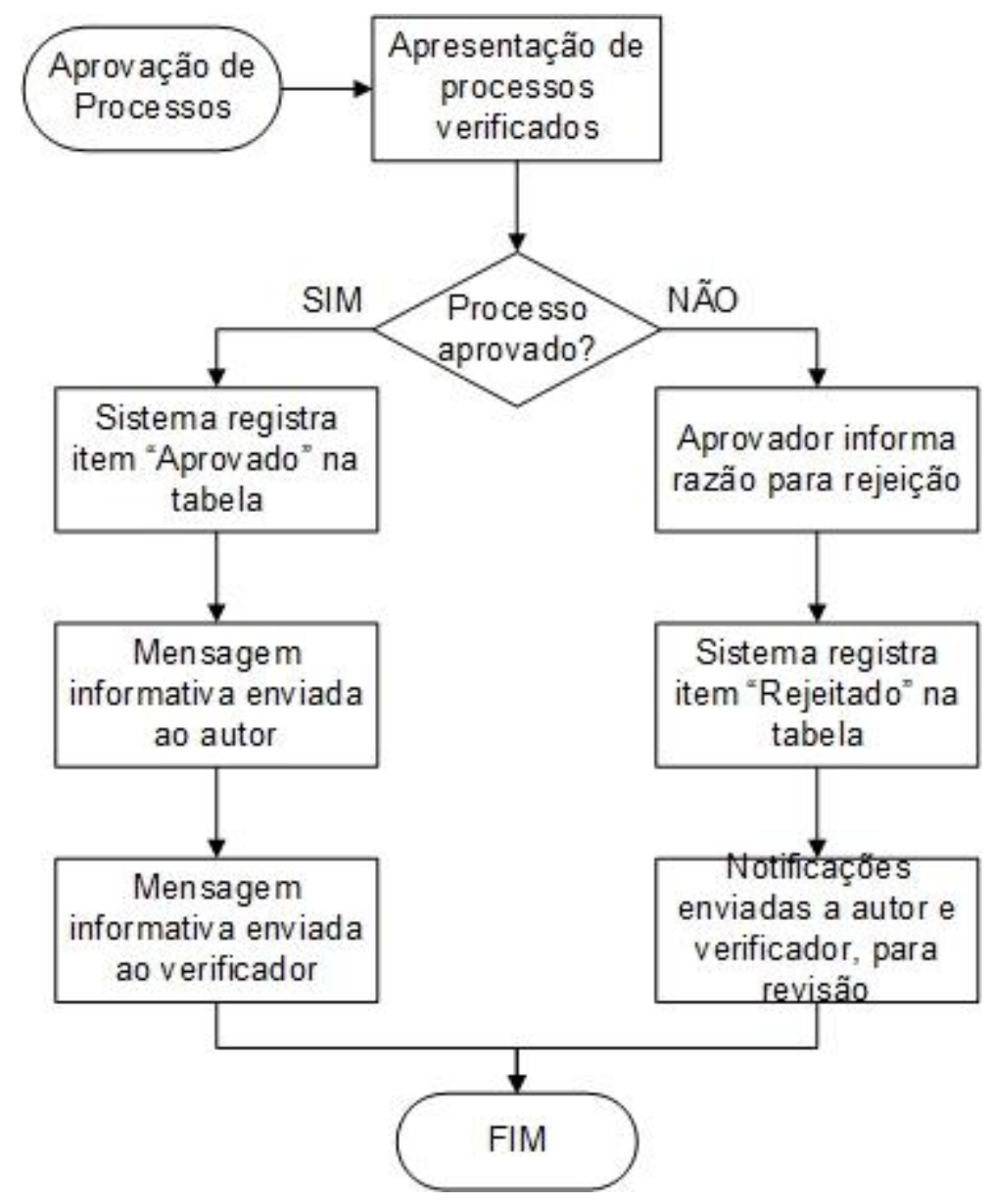

\subsection{Controle de Inspeção e Testes}

Os requisitos da CNEN-NN-1.16 referentes a tal controle estão especificados na seção 4.9 "Controle de Inspeção e Testes". Esta seção possui quatro subseções relativas a programa de inspeção, testes, calibração, controle de equipamentos de teste e medição, situações e estado operacional dos itens. A seguir, segue a seção 4.9.1 "Programa de Inspeção":

4.9.1.1 Deve ser estabelecido e executado um programa de inspeção de itens importantes à segurança e de atividades que influem na qualidade, pela ou para a organização responsável pela atividade a fim de verificar a conformidade com normas ou documentos;

4.9.1.2 As inspeções devem ser realizadas:

a) por pessoas diferentes das que executam as atividades a serem inspecionadas; $e$ 
b) para cada etapa de execução onde seja necessário assegurar a qualidade, inclusive durante a armazenagem.

4.9.1.3 O programa de inspeção deve proporcionar:

a) controle indireto pela monitoração dos processos, equipamentos e pessoal, para os casos em que é impossível a inspeção dos itens processados ou em que é necessário a monitoração adicional do processo ; e

b) emprego conjunto da inspeção do item processado e da monitoração do processo, quando o controle for inadequado sem ambas.

4.9.1.4 Devem ser indicados em documentos apropriados, os pontos de espera que requerem a inspeção ou testemunho de inspeção por organizações designadas, cuja aprovação documentada é indispensável para o prosseguimento do trabalho além do ponto de espera especificado.

4.9.1.5 Um programa para a inspeção em serviço de sistemas, estruturas e componentes deve ser planejado $e$ executado pela ou para a organização responsável pela operação da instalação. Os resultados desses programas devem ser analisados em comparação com dados básicos de referência.

4.9.1.6 Quando uma amostra for utilizada para verificação da aceitabilidade de um grupo de itens, o procedimento de amostragem deve basear-se em práticas padronizadas, bem como fornecer justificativa adequada relativa ao processo de seleção e tamanho da amostra. (CNEN, 2000).

O detalhamento realizado utilizando os itens correspondentes da regulação americana segue abaixo:

- Planejamento da Inspeção

O planejamento da inspeção deve ser realizado e documentado. Os planos de inspeção podem ser documentos definidos por controles de processo, ou uma parte integrante dos documentos de execução já aprovados.

Os representantes das organizações técnicas e/ou indivíduos interessados que tenham sido treinados e qualificados em práticas e conceitos de controle de qualidade podem participar das atividades de planejamento.

Códigos, normas, especificações e documentos de projeto devem ser utilizados para o desenvolvimento dos planos de inspeção.

Os elementos dos planos de inspeção devem identificar:

1. As características a serem inspecionadas. 
2. A descrição do processo de inspeção com monitoramento do que será utilizado.

3. Identificação da organização responsável pela realização da inspeção.

4. Identificação dos pontos de controle obrigatórios, quando necessário.

5. Critérios de aceitação.

6. Equipamentos de medição e testes a serem utilizados para realizar a inspeção para garantir que o equipamento seja adequado em tipo, alcance, precisão e tolerância para realizar a função pretendida.

7. Caso aplicável, identificação de um respectivo plano de amostragem.

8. Métodos para registrar os resultados da inspeção.

\section{- Seleção de Pessoal para Realização das Inspeções}

Os indivíduos que realizarem inspeções para verificar a conformidade de um item com os critérios de aceitação especificados devem ser qualificados nos requisitos da presente seção.

As inspeções realizadas por pessoal durante 0 treinamento em exercício devem ser feitas sob a observação direta e supervisão de pessoal qualificado e a verificação da conformidade deve ser feita por pessoal qualificado até que a certificação adequada seja alcançada.

Registradores de dados, operadores de equipamentos, ou outros membros da equipe de inspeção ou de testes que são supervisionados por um inspetor qualificado, não precisam obrigatoriamente ser inspetores qualificados.

As inspeções de aceitação devem ser realizadas por pessoal diferente dos que realizaram ou supervisionaram diretamente o trabalho a ser inspecionado e tal pessoal não deve se reportar diretamente ao supervisor imediatamente responsável pela realização do trabalho.

- Pontos de Controle da Inspeção

Quando pontos de controle obrigatórios são utilizados para controlar o trabalho que não pode prosseguir sem o consentimento específico da organização que instituiu o ponto de controle, então tais pontos de controle devem ser indicados em documentos pertinentes. 
O consentimento para desconsiderar pontos de retenção específicos deve estar documentado antes de se continuar o trabalho após o ponto de controle designado.

\section{- Inspeções e Monitoramento de Processo}

Itens em processo ou em construção devem ser inspecionados quando necessário, para verificação da qualidade. Caso a verificação de itens processados seja impossível ou desvantajosa, o controle indireto deve ser realizado por monitoramento dos métodos de processamento, equipamentos e pessoal.

Tanto o monitoramento da inspeção como o do processo devem ser efetuados quando o controle for insuficiente com apenas um método.

Uma combinação de métodos de inspeção e monitoramento de processo, quando utilizada, deve ser realizada de forma sistemática para garantir que os requisitos especificados para controle do processo e da qualidade do item sejam atendidos durante todo o processo.

Controles devem ser estabelecidos e documentados pela coordenação, e sequenciamento do trabalho em pontos de inspeção estabelecidos durante as fases sucessivas do processo ou construção.

\section{- Inspeção Final}

A inspeção final deve ser planejada para que se chegue a uma conclusão quanto à conformidade do item com os requisitos especificados.

Itens acabados devem ser inspecionados quanto à integridade, marcações, calibração, ajustes, proteção contra danos, ou outras características conforme necessário para que se verifique a qualidade e conformidade dos itens com os requisitos especificados.

Registros de qualidade não examinados previamente devem ser examinados quanto à adequação e integridade.

Inspeções finais incluem uma revisão dos resultados e resolução das não conformidades identificadas por inspeções anteriores.

No caso de modificações, reparos ou substituições de itens realizados após a inspeção final, deve-se exigir nova inspeção ou novo teste, conforme o caso, para verificação da aceitabilidade. 
Em seguida, a segunda subseção 4.9.2 "Programa de Testes":

4.9.2.1 Deve ser estabelecido um programa de testes para assegurar a identificação, a execução e a documentação de todos os testes exigidos, a fim de demonstrar que as estruturas, sistemas e componentes funcionarão satisfatoriamente em serviço.

4.9.2.2 O programa de testes deve abranger todos os testes exigidos e incluir, quando apropriado, ensaio $s$ de qualificação de procedimentos e equipamentos, ensaios de qualificação de protótipos, ensaio $s$ de demonstração antes da instalação, testes pré-operacionais e de partida, e testes de operação.

4.9.2.3 Os testes devem ser realizados de acordo com procedimentos escritos que:

a) incorporem os requisitos e limites de aceitação especificados em documentos de projeto;

b) incluam cláusulas para garantir que os pré-requisitos para um dado teste tenham sido atendidos; e

c) contenham cláusulas para assegurar que os testes sejam realizados sob condições ambientais adequadas, por pessoal treinado apropriadamente, usando instrumentação adequada e corretamente calibrada.

4.9.2.4 Os resultados dos testes devem ser documentados e avaliados para garantir que os requisitos tenham sido satisfeitos. (CNEN, 2000).

O detalhamento realizado utilizando os itens correspondentes da regulação americana segue abaixo:

- Planejamento de Testes

O planejamento de testes deve exigir que os documentos de sua aplicação venham a garantir os seguintes:

1. Identificação dos documentos de aplicação a serem desenvolvidos para controlar e realizar testes, bem como fornecer critérios para: determinar os requisitos de precisão de equipamentos de teste e determinar quando os testes serão necessários, bem como definir como e quando os testes serão realizados.

2. Disposições para realização de testes de qualificação de protótipos, componentes ou recursos, incluindo testes de verificação de projeto, o mais breve possível, antes da instalação. 
3. Identificação do item a ser testado e os requisitos de testes e limites de aceitação contidos nos projetos aplicáveis e documentos de aquisição.

4. Identificação de métodos de testes a serem empregados e instruções para sua realização.

5. Pontos de controle de inspeção obrigatórios com testemunha definidos pela organização responsável pela sua instituição.

6. Métodos para registrar dados e resultados.

7. Provisões para garantir que os pré-requisitos de teste sejam cumpridos.

8. Seleção e identificação do equipamento de medição e teste (EM\&T) a ser utilizado para realizar o teste, para garantir que o EM\&T seja apropriado quanto ao tipo, alcance, precisão, e tolerância para realizar a função pretendida.

- Resultados de Testes

Os resultados dos testes devem ser documentados e sua conformidade com os critérios de aceitação deve ser avaliada por uma pessoa qualificada dentro da organização responsável por garantir que os requisitos de teste sejam satisfeitos.

- Documentação de Testes

A documentação de testes deve, pelo menos, identificar:

1. Item ou produto de trabalho testado.

2. Data do teste.

3. Nome do executor e registros dos dados.

4. Tipo de observação.

5. Identificação de critérios de teste ou documentos de referência utilizados para determinar a aceitação.

6. Resultados e aceitabilidade do teste.

7. Medidas tomadas em relação a quaisquer desvios observados.

8. Nome da pessoa que avaliou e aceitou os resultados do teste.

9. Identificação do EM\&T utilizado durante o ensaio, incluindo o número de identificação e a data de vencimento para a próxima calibração. 
Na sequência, a terceira subseção 4.9.3 "Calibração e Controle de Equipamentos de Teste e de Medição":

4.9.3.1 Devem ser estabelecidas medidas para assegurar que as ferramentas, calibres, instrumentos e outros equipamentos e aparelhos de inspeção, medição e testes, usados para determinar a conformidade com os critérios de aceitação, sejam de faixa, tipo, exatidão e precisão adequados.

4.9.3.2 Os equipamentos de teste e medição utilizados em atividades que influem na qualidade devem ser controlados, calibrados e ajustados a intervalos especificados ou antes do uso, para manter a precisão dentro dos limites necessários.

4.9.3.3 No caso de constatação de desvios de precisão além dos limites prescritos, deve ser efetuada uma avaliação da validade das medições e testes anteriores, bem como uma reavaliação da aceitação dos itens já testados.

4.9.3.4 Devem ser estabelecidos controles para garantir o manuseio, a armazenagem e o uso corretos dos equipamentos calibrados. (CNEN, 2000).

O detalhamento realizado utilizando os itens correspondentes da regulação americana segue abaixo:

- Calibração

Os EM\&Ts, incluindo os equipamentos que contêm programa de computador incorporado ou equipamento programável, devem ser calibrados e ajustados em intervalos prescritos, ou antes do uso, por equipamentos certificados segundo os padrões de referência e de transferência nacionalmente reconhecidos. Se não houver padrões reconhecidos nacionalmente, ou constantes físicas, a base para a calibração deve ser documentada. Aplicações de aquisição e controle de dados, parte integrante das operações, manutenção ou calibração de aparelhos de testes de investigação, devem ser verificados, validados e documentados em conjunto com os planos de controle de testes e, em conjunto com os EM\&T, ou equipamentos de testes como uma unidade operacional.

Os padrões de calibração devem possuir uma precisão maior do que a precisão exigida para os padrões a serem utilizados. 
1. Se os padrões de calibração com precisão maior do que exigida por padrão não existirem ou não estiverem disponíveis, padrões de calibração com precisão igual à precisão de calibração necessária podem ser utilizados, desde que adequados para os requisitos.

2. A base para a aceitação de calibração deve ser documentada e autorizada pela administração responsável. O nível de administração autorizado a executar esta função deve ser identificado.

As normas de calibração utilizadas para a calibração de EM\&T devem possuir uma precisão de, pelo menos, quatro vezes a precisão necessária do equipamento que está sendo calibrado ou, quando tal não for possível, deve ter uma precisão que garanta que o equipamento a ser calibrado vai estar dentro da tolerância exigida. A base de aceitação deve ser aprovada pela administração responsável. O nível de administração autorizado a executar esta função deve ser identificado.

O método e o intervalo de calibração para cada dispositivo devem ser definidos com base no tipo de equipamento, características de estabilidade, exatidão requerida, precisão, utilização pretendida, grau de utilização, e outras condições que afetem o controle de medição. Para EM\&Ts utilizados em somente uma aplicação, a calibração deve ser feita antes e após o uso.

A calibração ou verificação do equipamento deve ser efetuada:

1. Quando a exatidão do EM\&T for suspeita.

2. Quando houver passado a data de calibração, ou prazo desde a última calibração do EM\&T.

Os EM\&Ts calibrados devem ser rotulados, etiquetados, ou identificados com outra forma de sinalização adequada ou documentados para indicar a data de vencimento da próxima calibração.

EM\&Ts calibrados devem ser identificados de forma exclusiva para garantir a rastreabilidade de seus dados de calibração.

Atualizações no programa contido nos EM\&Ts que afetem a calibração tornam a recalibração do equipamento necessária antes de nova utilização. 
- Equipamentos de Medição e Teste Descalibrados

Os EM\&Ts serão considerados descalibrados e não poderão ser escalados para uso até realizada a calibração caso qualquer uma das seguintes condições ocorra:

1. A validade ou intervalo da calibração passou e não houve recalibração.

2. O dispositivo apresenta resultados reconhecidamente errôneos.

3. O estado de calibração não pode ser determinado.

Os EM\&Ts descalibrados devem ser controlados. Os controles devem incluir os seguintes requisitos:

1. Os EM\&Ts descalibrados devem ser marcados, isolados e não utilizados, ou de alguma outra forma controlados para evitar nova utilização até que tenham sido recalibrados.

2. Quando o EM\&T estiver descalibrado, a validade dos resultados obtidos com o equipamento desde sua última calibração deve ser questionada. A avaliação deve incluir a determinação de aceitabilidade dos dados coletados anteriormente, processos monitorados, ou itens previamente inspecionados ou testados. A avaliação deve ser documentada. Se a avaliação determinar que processos monitorados ou itens inspecionados ou testados são suspeitos, eles devem ser documentados como não conformes.

Se o EM\&T estiver constantemente descalibrado durante o processo de recalibração, ele deve ser reparado ou substituído.

\section{- Equipamentos de Medição e Teste Perdidos ou Abandonados no Local}

Quando um EM\&T é perdido ou abandonado no local, a validade dos resultados obtidos com tal equipamento desde a sua última calibração válida deve ser revista.

A revisão deve incluir a determinação da aceitabilidade dos dados coletados anteriormente, processos monitorados, ou itens previamente inspecionados ou testados.

A revisão deve ser documentada. Se a revisão determinar que processos monitorados ou itens inspecionados ou testados são suspeitos, eles devem ser documentados como não conformes. 
- Manuseio, Armazenagem e Utilização

EM\&Ts devem ser devidamente manuseados e armazenados para manter a precisão.

A seleção de EM\&Ts deve ser controlada para garantir que esses itens sejam do tipo adequado para o uso pretendido.

Por fim, a quarta subseção 4.9.4 "Situações das Inspeções, Testes e Estado Operacional de Itens":

4.9.4.1 A situação das inspeções e testes de itens individuais da instalação deve ser identificada pelo uso de marcação, carimbos, etiquetas, rótulos, cartões de controle, registros de inspeção, localização física ou outros meios adequados que possam indicar a aceitação ou não conformidade de itens com relação a inspeção e testes realizados.

4.9.4.2 A identificação da situação das inspeções e testes deve ser mantida, conforme necessário, ao longo da fabricação, instalação e operação do item, a fim de assegurar que somente sejam usados, instalados ou operados, os itens aprovados nas inspeções e testes.

4.9.4.3 Devem ser estabelecidas medidas para indicar o estado operacional de sistemas e componentes da instalação, tais como: colocação de etiquetas em válvulas e chaves para evitar operação indevida. (CNEN, 2000).

O detalhamento realizado utilizando os itens correspondentes da regulação americana segue abaixo:

- Identificação de Itens

Os itens que tenham passado satisfatoriamente pelas inspeções e testes necessários devem ser identificados.

Os métodos de identificação devem impedir a instalação, uso ou operação inadvertida de itens que não tenham passado pelas inspeções e testes necessários.

- Indicação de estado

O estado da inspeção e dos ensaios exigidos deve ser indicado quando necessário para impedir o desvio inadvertido de tais inspeções e testes. 
O estado das inspeções e testes deve ser identificado nos itens ou nos documentos rastreáveis aos itens.

O estado deve ser mantido pelo uso de indicadores de estado legíveis e facilmente reconhecíveis (por exemplo, etiquetas, marcações, rótulos e selos) ou outros meios (por exemplo, registros de teste, inspeção ou transporte).

A pessoa responsável pela aplicação e remoção de indicadores de estado deve ser especificada.

Para evitar o uso ou operação inadvertida de um item que esteja fora de serviço (por exemplo, um item não conforme, inoperante ou com defeito), os indicadores de estado, como marcas ou marcações, devem ser colocados em todos os locais onde a operação do item possa ser iniciada (por exemplo, painéis de controle, interruptores, disjuntores, válvulas ou sistemas).

As páginas a seguir são a de "Inclusão de Inspeções e Testes" e a de "Consulta de Edição de Inspeções e Testes", utilizadas pelo executor; "Verificação de Inspeções e Testes", que será utilizada pelo verificador; e "Aprovação de Inspeções e Testes", utilizada pelo gerente.

\subsubsection{Página Inclusão de Inspeções e Testes}

Itens a serem apresentados na página "Inclusão de Inspeções e Testes":

- Título "Inclusão de Inspeções e Testes";

- Nome do usuário e data / horário de acesso;

- Caixa de entrada "Tipo de inspeção ou teste";

- Caixa de entrada "Instalação de realização";

- Caixa de entrada "Pessoal a realizar a inspeção ou teste";

- Caixa de entrada "Data de realização";

- Caixa de entrada "Exigências e normas - aplicáveis a inspeção, teste, pessoal e equipamento";

- Caixa de entrada "Equipamentos (incluir dados de calibração ou outros, que atestem a qualidade)";

- Caixa de entrada "Validade";

- Botão "Salvar"; 
- Botão "Cancelar";

- Botão "Sair".

Operações elementares:

1) Digitar "Tipo de inspeção ou teste";

2) Digitar "Instalação de realização";

3) Digitar "Pessoal a realizar a inspeção ou teste";

4) Digitar "Data de realização";

5) Digitar "Exigências e normas - aplicáveis a inspeção, teste, pessoal e equipamento";

6) Digitar "Equipamentos (incluir dados de calibração ou outros, que atestem a qualidade)";

7) Digitar "Validade";

8) Clicar no botão "Salvar". O sistema grava os dados na tabela correspondente. Informativo é enviado para o Verificador, avisando sobre a inclusão de nova inspeção ou teste.

O fluxograma correspondente encontra-se na Figura 21.

Figura 21 - Fluxograma "Inclusão de Inspeções e Testes"

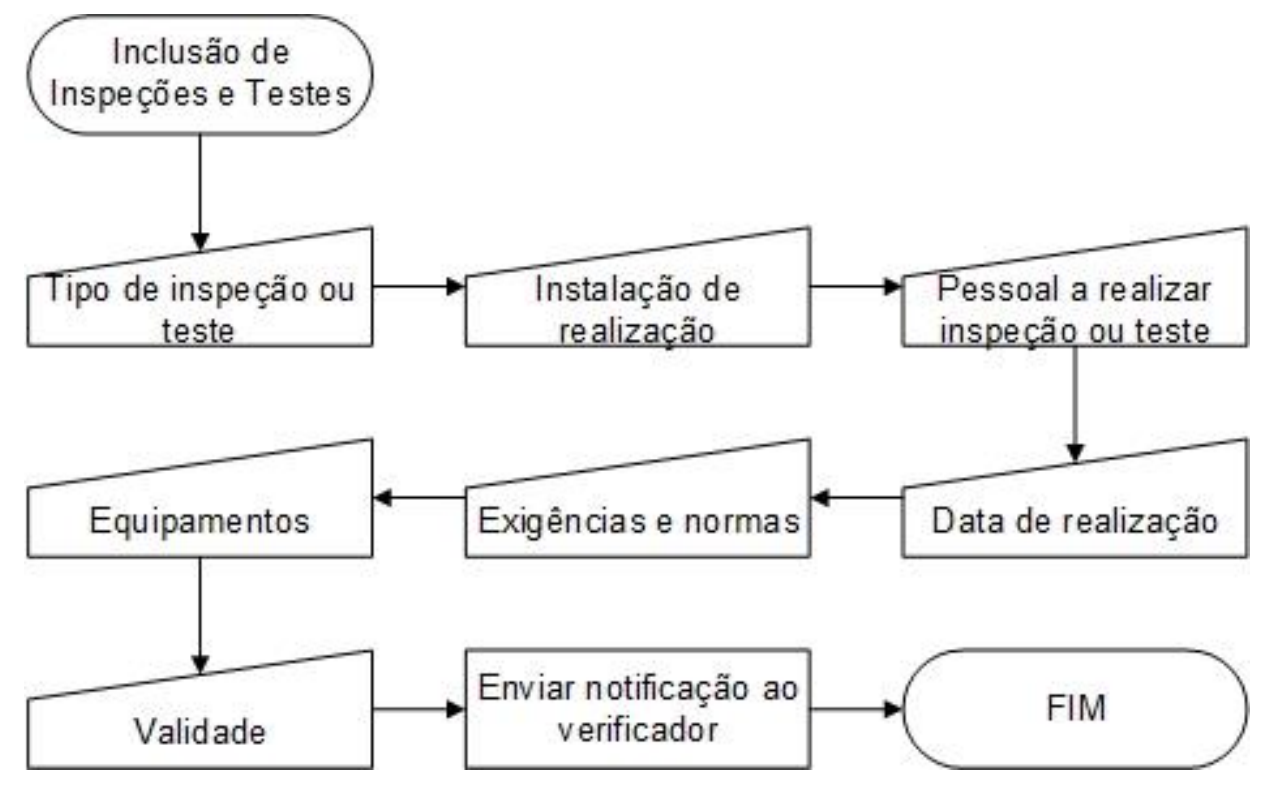


5.6.2 Página Consulta e Edição de Inspeções e Testes

Itens a serem apresentados na página "Consulta e Edição de Inspeções e Testes":

- Título "Consulta e Edição de Inspeções e Testes";

- Nome do usuário e data / horário de acesso;

- Botão "Pesquisar";

- Botão de escolha "Pesquisa por Tipo de inspeção ou teste; Instalação de realização; Pessoal a realizar inspeção ou teste; Data de realização; Equipamentos";

- Caixa de entrada "Dado a pesquisar";

- Caixa de entrada "Processo(s) pesquisado(s)";

- Botão "Modificar";

- Botão "Sair".

\section{Operações elementares:}

1) Digitar uma palavra-chave correspondente à(s) inspeção(ões) ou teste(s) a ser(em) buscada(s);

2) Utilizar o botão de escolha para selecionar no campo de pesquisa a palavrachave digitada: por Tipo de inspeção ou teste; Instalação de realização; Pessoal a realizar inspeção ou teste; Data de realização; ou Equipamentos. Clicar em "Pesquisar";

3) O sistema busca a palavra-chave no campo de pesquisa selecionado na tabela correspondente. Caso não encontre nenhum item, aparece a mensagem "Nenhum item encontrado.". Retornar ao início da página "Consulta e Edição de Inspeções ou Testes".

4) $O(s)$ item(ns) encontrado(s) é(são) listado(s) na Caixa de entrada "Inspeção(ões) ou Teste(s) Pesquisado(s)" (até 5 itens; para itens excedentes, cria-se uma barra de rolagem vertical à direita da lista);

5) Caso desejado, clicar em um dos itens listados e clicar em "Modificar";

6) Ao clicar em "Modificar", o sistema verifica qual item pesquisado foi selecionado; caso nenhum o tenha, aparece a mensagem "Nenhum item selecionado.". 
7) Caso haja um item selecionado, o sistema traz os dados nos mesmos campos da página "Inclusão de Processos", passíveis de modificações. O usuário modifica os valores de acordo e clica em "Salvar". O sistema atualiza a tabela. Retornar ao início da página "Consulta e Edição de Inspeções ou Testes". É enviada ao verificador notificação de modificação de inspeções ou testes.

8) Clicar em "Sair". O sistema fecha.

O fluxograma correspondente encontra-se na Figura 22.

Figura 22 - Fluxograma "Consulta e Edição de Inspeções ou Testes"

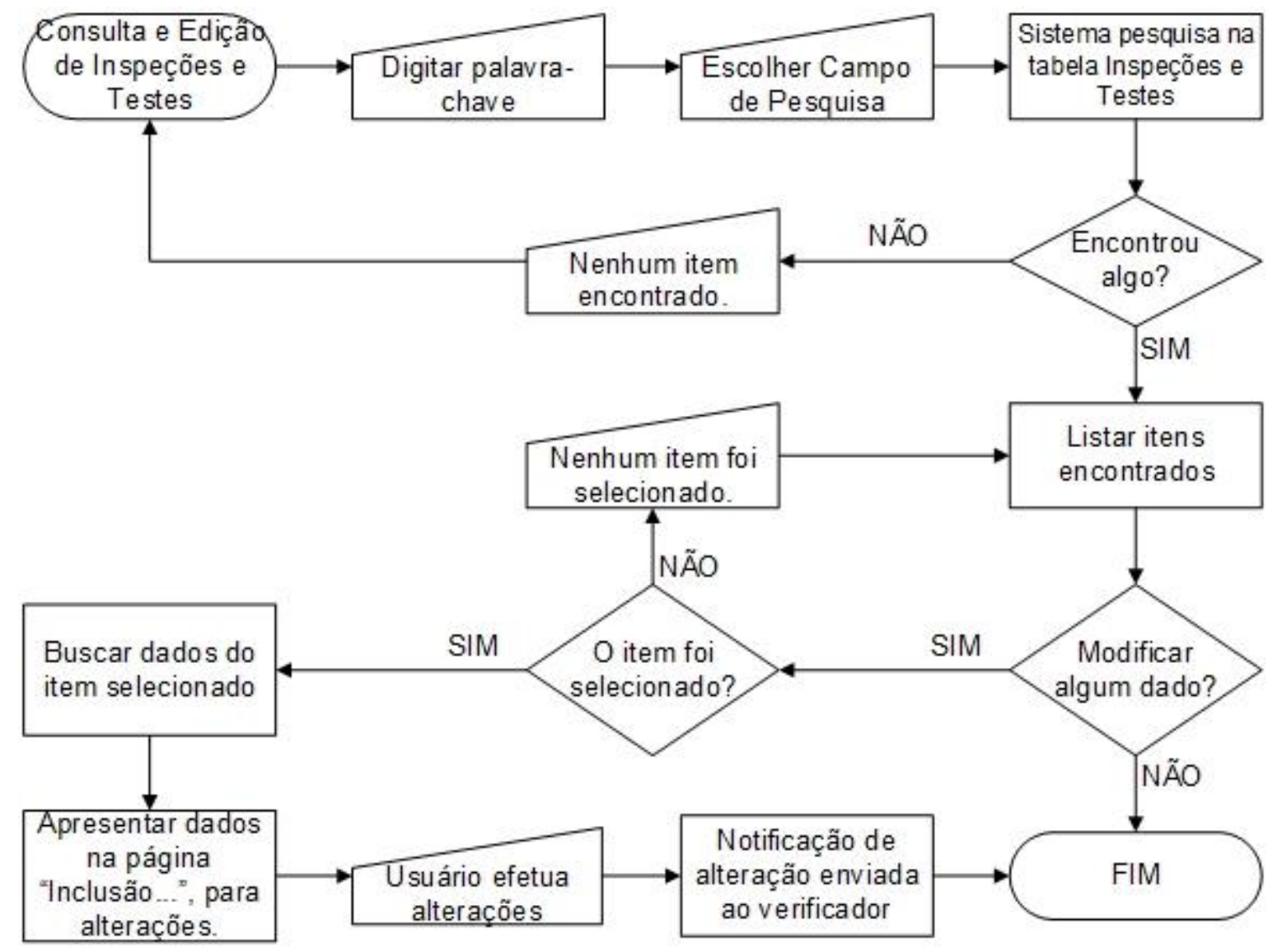

\subsubsection{Página Verificação de Inspeções ou Testes}

Itens a serem apresentados na página "Verificação de Inspeções ou Testes":

- Inicialmente, a página de Entrada;

- Depois, a página com o título "Verificação de Inspeções ou Testes"; 
- Caixa de texto com lista de itens a serem verificados (até 3 ou 5);

- Botão "Aceito";

- Botão "Rejeitado";

- Botão "Cancelar";

- Botão "Sair";

- Caixa de texto "Item aceito?" - incluir botões "Sim" e "Não";

- Caixa de texto "Item rejeitado?" - incluir botões "Sim" e "Não".

Operações elementares:

1) O verificador recebeu uma notificação de inclusão de inspeções ou testes. Após ser autorizado via login e senha, ele abre a página "Verificação de Inspeções ou Testes".

2) Os processos incluídos aparecem na página. O verificador seleciona o item e analisa os dados. Na sequência, ele clica no botão "Aceito" ou "Rejeitado".

3) Se o verificador clicar em "Aceito", a informação de "verificado" é registrada no banco de dados, uma mensagem informativa é enviada para o autor dos dados, e uma notificação é enviada ao responsável pela aprovação final.

4) Caso o verificador clique em "Rejeitado", ele digita o motivo pelo qual o item foi rejeitado, e depois clica em "Enviar". Tal informação é registrada no banco de dados, e uma notificação é enviada para o autor dos dados, para que este revise os mesmos.

O fluxograma correspondente encontra-se na Figura 23. 
Figura 23 - Fluxograma "Verificação de Inspeções ou Testes"

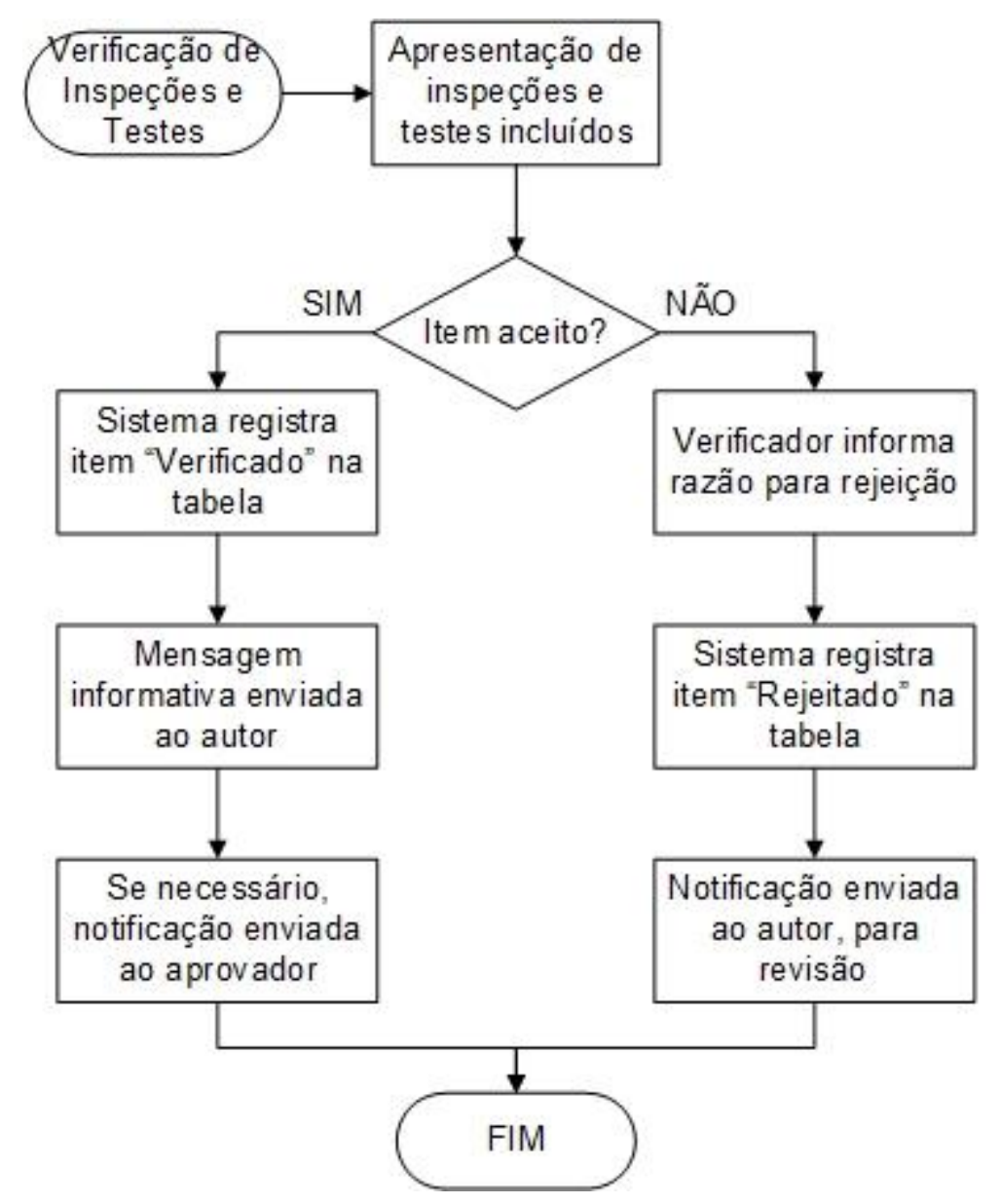

5.6.4 Página Aprovação de Inspeções e Testes

Itens a serem apresentados na página "Aprovação de Inspeções e Testes":

- Inicialmente, a página de Entrada;

- Depois, a página com o título "Aprovação de Inspeções ou Testes";

- Caixa de texto com lista de itens a serem aprovados (até 3 ou 5);

- Botão "Aprovado";

- Botão "Recusado";

- Botão "Cancelar";

- Botão "Sair";

- Caixa de texto "Item aprovado?" - incluir botões "Sim" e "Não";

- Caixa de texto "Item recusado?" - incluir botões "Sim" e "Não". 
Operações elementares:

1) O aprovador recebeu uma notificação de inspeções ou testes verificados. Após ser autorizado via login e senha, ele abre a página "Aprovação de Inspeções ou Testes".

2) As inspeções ou testes verificados aparecem na página. $O$ aprovador seleciona 0 item e analisa os dados. Na sequência, ele clica no botão "Aprovado" ou "Recusado".

3) Se o aprovador clicar em "Aprovado", a informação de "aprovado" é registrada no banco de dados, e mensagens informativas da aprovação final são enviadas para o autor dos dados e o verificador.

4) Caso o aprovador clique em "Recusado", ele digita o motivo pelo qual o item foi recusado, e depois clica em "Enviar". Tal informação é registrada no banco de dados, e notificações são enviadas para o autor dos dados e para o verificador, para revisão.

O fluxograma correspondente encontra-se na Figura 24. 
Figura 24 - Fluxograma "Aprovação de Inspeções e Testes"

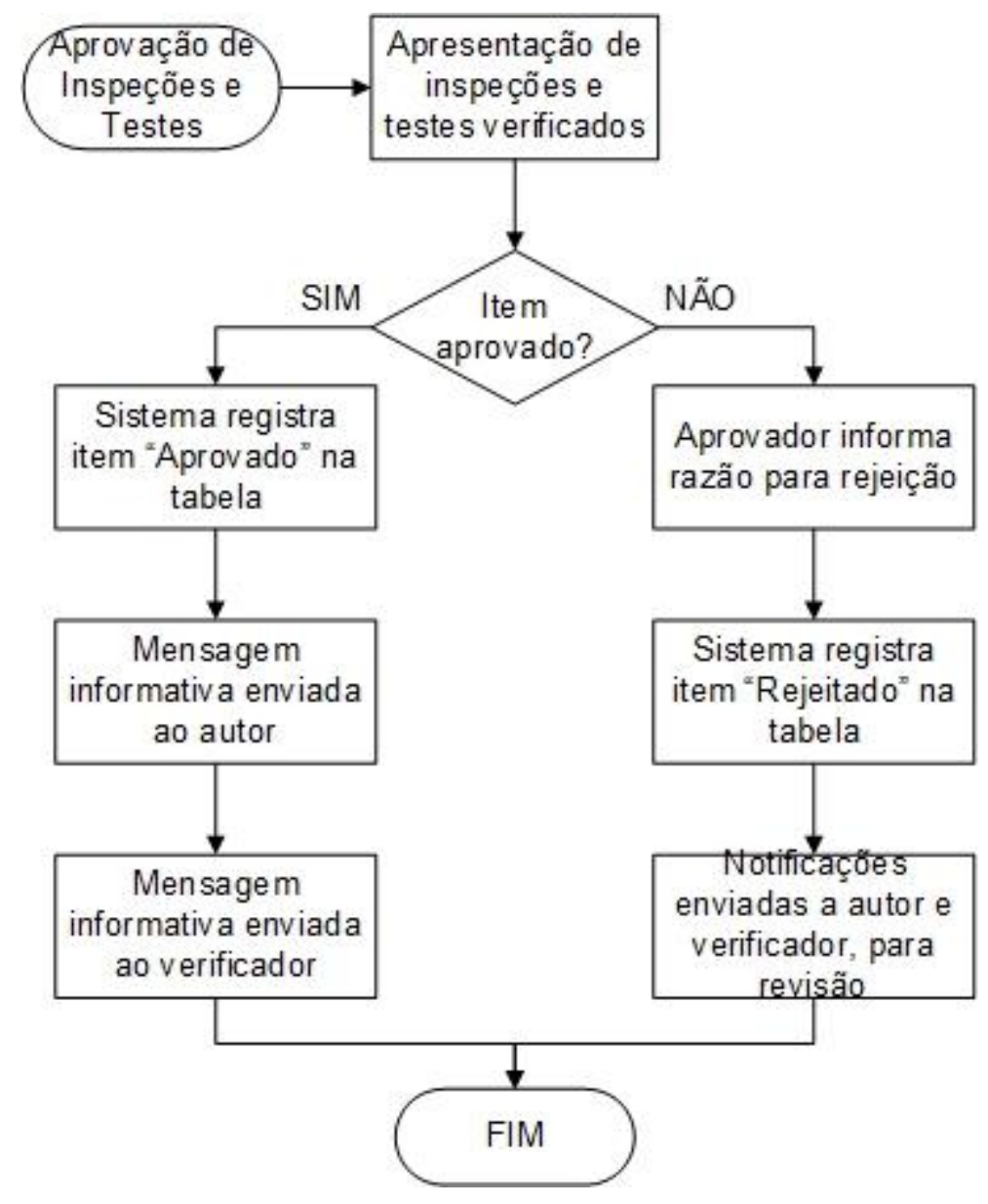

\subsection{Controle de Itens Não Conformes}

Os requisitos da CNEN-NN-1.16 para este item estão especificados na seção 4.10 "Controle de Itens Não Conformes". Esta seção possui duas subseções relacionadas a requisitos e avaliação e destinação. A seguir, segue a primeira subseção 4.10.1 "Requisitos Gerais":

4.10.1.1 Devem ser estabelecidas medidas para controlar itens não conformes, a fim de evitar seu uso ou instalação inadvertida.

4.10.1.2 Os itens não conformes devem ser identificados através de marcas, etiquetas e/ou isolamento físico, para garantir seu controle.

4.10.1.3 Devem ser estabelecidas, documentadas e implementadas medidas para controlar o processamento, a liberação ou a instalação de itens não conformes. (CNEN, 2000). 
O detalhamento realizado utilizando os itens correspondentes da regulação americana é apresentado abaixo:

\section{- Documentação, Notificação e Avaliação de Itens Não Conformes}

As não conformidades devem ser documentadas e notificadas aos níveis adequados de administração responsáveis para tal. Além disso, as organizações afetadas pela não conformidade devem ser notificadas por escrito.

A documentação de não conformidade deve identificar claramente e descrever as características que não estejam em conformidade com os critérios especificados.

As características da não conformidade devem ser revistas, e a disposição recomendada de itens não conformes deve ser proposta e aprovada. A revisão deve incluir determinação da necessidade das medidas corretivas cabíveis, em conformidade com as normas da CNEN.

As disposições recomendadas devem ser avaliadas e aprovadas por pessoas que sejam independentes do pessoal que realizou tais disposições.

O pessoal que realizar as avaliações para determinar a disposição deve demonstrar competência na área específica que está sendo avaliada, possuir compreensão adequada dos requisitos, e acesso às informações pertinentes. A responsabilidade e a autoridade para rever, avaliar e aprovar a disposição, e não conformidades de encerramento, devem ser especificadas.

O processamento posterior, entrega, instalação ou uso de um item não conforme deve ser controlado enquanto se aguarda a avaliação e aprovação da disposição. Não conformidades devem ser corrigidas ou separadas antes do início do programa de testes pré-operacionais do item.

\section{- Identificação de Itens Não Conformes}

Os itens não conformes devem ser identificados por marcação, etiquetação, ou outros métodos que não afetem negativamente sua utilização final. A identificação deve ser legível e facilmente reconhecível.

Se a identificação de um item não conforme não for possível, então o recipiente, pacote ou área separada de armazenamento, conforme o caso, deve ser identificado. 
Em seguida, a segunda subseção 4.10.2 "Avaliação e Destinação de Itens Não Conformes":

4.10.2.1 Os itens não conformes devem ser avaliados e classificados para fins de aceitação no estado, rejeição, reparação ou de serem refeitos, de acordo com procedimentos documentados.

4.10.2.2 A responsabilidade pela avaliação e classificação e a autoridade para a destinação de itens não conformes devem ser definidas.

4.10.2.3 Os itens não conformes aceitos, envolvendo um desvio em relação aos requisitos de aquisição, devem ser relatados ao comprador.

4.10.2.4 A descrição de alterações ou desvios de itens não conformes que tenham sido aceitos, deve ser documentada, a fim de indicar a condição "como construído". (CNEN, 2000).

O detalhamento realizado utilizando os itens correspondentes da regulação americana segue abaixo:

- Separação de Itens Não Conformes

Itens não conformes devem ser separados, colocando-os em uma área claramente identificada e designada até o adequado encaminhamento.

Se a separação for impraticável ou impossível devido às condições físicas, outras precauções devem ser empregadas para se evitar a utilização inadvertida.

- Destinação de Itens Não Conformes

A destinação de itens não conformes para uso "como construído", uso limitado, descarte, reparo, ou retrabalho deve ser identificada e documentada.

A justificativa técnica para aceitação de um produto não conforme, que foi definido como reparado, de uso limitado ou "como construído", deve ser documentada.

Os itens que não atendem aos requisitos do projeto original, que são separados como uso "como construído" ou reparados, devem ser submetidos a medidas de controle compatíveis com as aplicadas ao projeto original. 
1. Se as alterações no documento especificado são necessárias para refletir a condição de "como construído", então a destinação deve exigir medidas para modificar o documento especificado, incluindo a não conformidade aceita.

2. Qualquer alteração de documento ou de registro de garantia da qualidade, exigida pela destinação da não conformidade, deve ser identificada em sua documentação, e quando cada documento ou registro for alterado, a justificativa para mudança deve identificar a documentação da não conformidade.

A destinação de um item a ser retrabalhado ou reparado deve conter um requisito para reexaminar (ex.: por inspeção, teste ou exame não destrutivo) o item para verificar a aceitação. Itens reparados ou retrabalhados devem ser reexaminados utilizando-se os critérios originais do processo de aceitação, a não ser que na destinação do item não conforme haja o estabelecimento de critérios de aceitação alternativos.

Itens de reposição devem ser inspecionados e testados de acordo com os requisitos de inspeção e teste originais, ou alternativas aceitáveis.

As páginas a seguir são a de "Inclusão de Itens Não Conformes" e a de "Consulta de Edição de Itens Não Conformes", utilizadas pelo executor; "Verificação de Itens Não Conformes", que será utilizada pelo verificador; e "Aprovação de Itens Não Conformes", utilizada pelo gerente.

\subsubsection{Página Inclusão de Itens Não Conformes}

Itens a serem apresentados na página "Inclusão de Itens Não Conformes":

- Título "Inclusão de Itens não conformes";

- Nome do usuário e data / horário de acesso;

- Caixa de entrada "Tipo de item não conforme";

- Caixa de entrada "Método de identificação";

- Caixa de entrada "Departamento";

- Caixa de entrada "Características quanto ao estado"; 
- Caixa de entrada "Localização da documentação com descrição das características";

- Botão "Salvar";

- Botão "Cancelar";

- Botão "Sair".

Operações elementares:

1) Digitar "Tipo de item não conforme";

2) Digitar "Método de identificação";

3) Digitar "Departamento";

4) Digitar "Características quanto ao estado";

5) Digitar "Localização da documentação com descrição das características";

6) Clicar no botão "Salvar". O sistema grava os dados na tabela correspondente. Informativo é enviado para o Verificador, avisando sobre a inclusão de novo item não conforme.

O fluxograma correspondente encontra-se na Figura 25.

Figura 25 - Fluxograma "Inclusão de Itens Não Conformes"

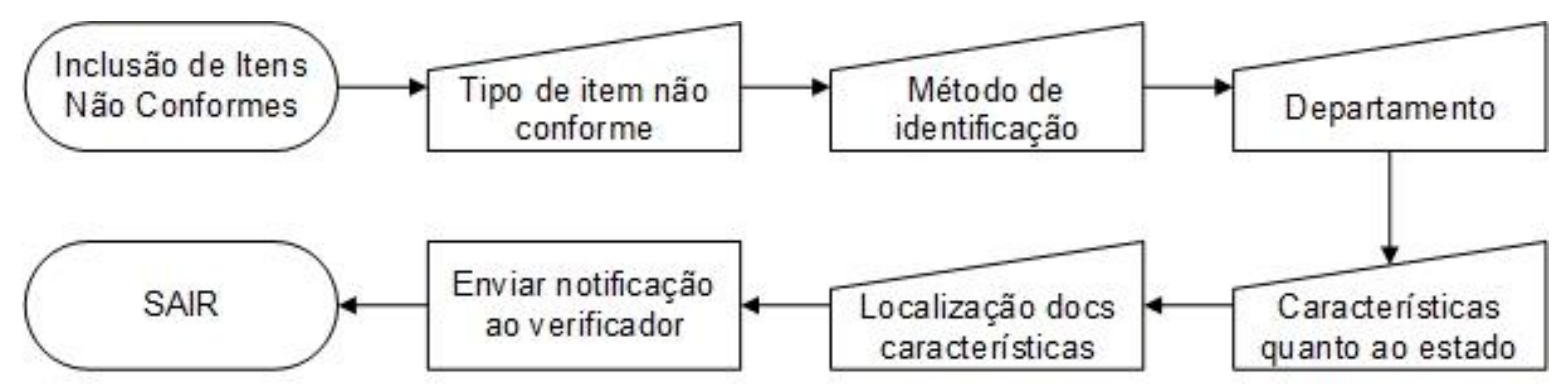

5.7.2 Página Consulta e Edição de Itens Não Conformes

Itens a serem apresentados na página "Consulta e Edição de Itens Não Conformes":

- Título "Consulta e Edição de Itens Não Conformes";

- Nome do usuário e data / horário de acesso;

- Botão "Pesquisar"; 
- Botão de escolha "Pesquisa por Tipo de item não conforme; Método de identificação; Departamento; Características quanto ao estado";

- Caixa de entrada "Dado a pesquisar";

- Caixa de entrada "Processo(s) pesquisado(s)";

- Botão "Modificar";

- Botão "Sair".

Operações elementares:

1) Digitar uma palavra-chave correspondente ao(s) item(ens) não conforme(s) a ser(em) buscado(s);

2) Utilizar o botão de escolha para selecionar no campo de pesquisa a palavrachave digitada: por Tipo de item não conforme; Método de identificação; Departamento; ou Características quanto ao estado. Clicar em "Pesquisar";

3) O sistema busca a palavra-chave no campo de pesquisa selecionado na tabela correspondente. Caso não encontre nenhum item, aparece a mensagem "Nenhum item encontrado.". Retornar ao início da página de Consulta e Edição de Itens Não Conformes.

4) $\mathrm{O}(\mathrm{s})$ item(ns) encontrado(s) é(são) listado(s) na Caixa de entrada "Item(ens) Não Conforme(s) Pesquisado(s)" (até 5 itens; para itens excedentes, cria-se uma barra de rolagem vertical à direita da lista);

5) Caso desejado, clicar em um dos itens listados e clicar em "Modificar";

6) Ao clicar em "Modificar", o sistema verifica qual item pesquisado foi selecionado; caso nenhum o tenha, aparece a mensagem "Nenhum item selecionado.".

7) Caso haja um item selecionado, o sistema traz os dados nos mesmos campos da página "Inclusão de Itens Não Conformes", passíveis de modificações. O usuário modifica os valores de acordo e clica em "Salvar". O sistema atualiza a tabela. Retornar ao início da página "Consulta e Edição de Itens Não Conformes". É enviada ao verificador notificação de modificação de itens não conformes.

8) Clicar em "Sair". O sistema fecha. 
Figura 26 - Fluxograma "Consulta e Edição de Itens Não Conformes"

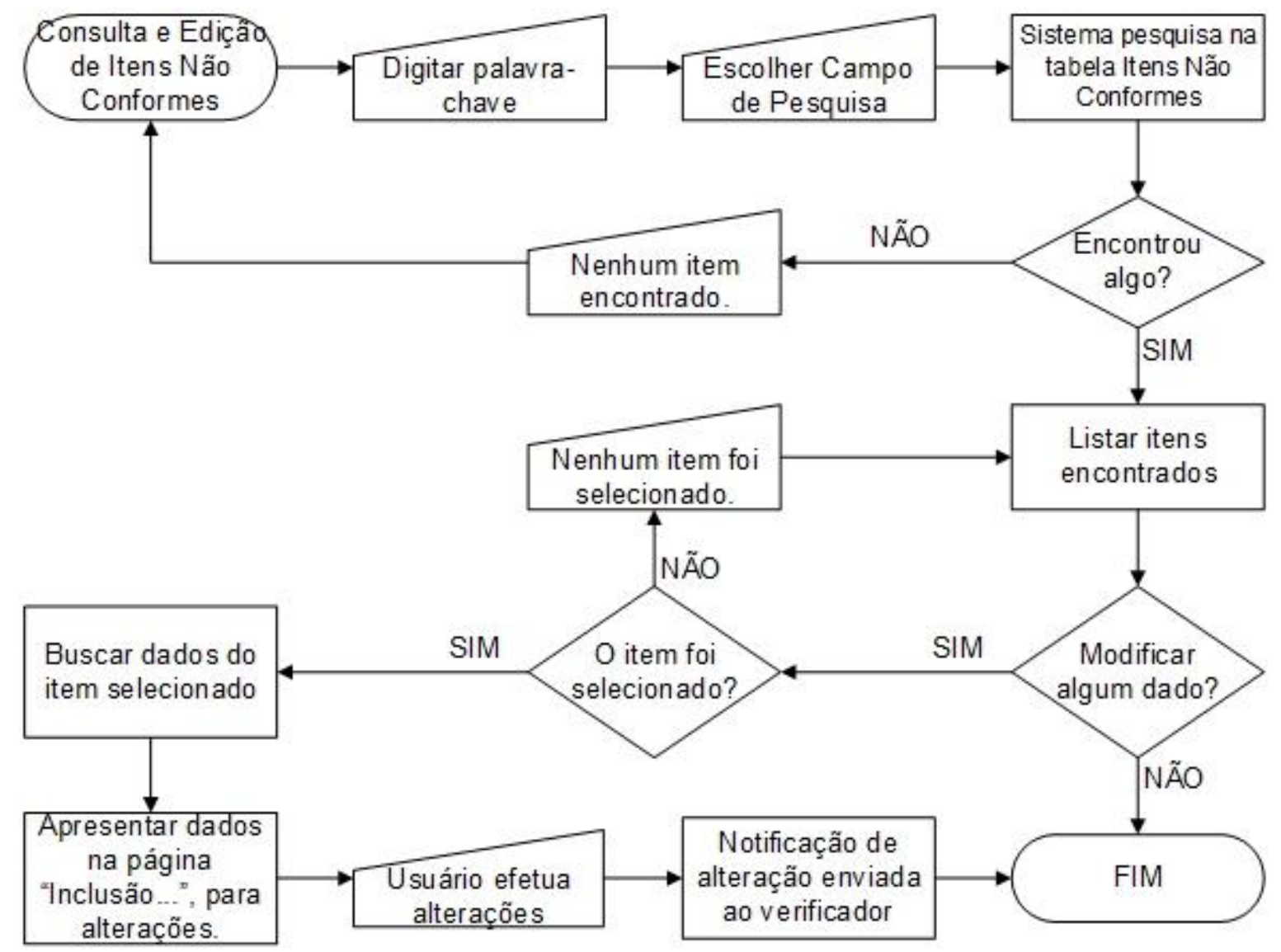

\subsubsection{Página Verificação de Itens Não Conformes}

Itens a serem apresentados na página "Verificação de Itens Não Conformes":

- Inicialmente, a página de Entrada;

- Depois, a página com o título "Verificação de Itens não conformes";

- Caixa de texto com lista de itens a serem verificados (até 5);

- Botão "Aceito";

- Botão "Rejeitado";

- Botão "Cancelar";

- Botão "Sair";

- Caixa de texto "Item aceito?" - incluir botões "Sim" e "Não";

- Caixa de texto "Item rejeitado?" - incluir botões "Sim" e "Não". 
1) O verificador recebeu uma notificação de inclusão de processos. Após ser autorizado via login e senha, ele abre a página "Verificação de Itens Não Conformes".

2) Os itens não conformes incluídos aparecem na página. O verificador seleciona o item e analisa os dados. Na sequência, ele clica no botão "Aceito" ou "Rejeitado".

3) Se o verificador clicar em "Aceito", a informação de "verificado" é registrada no banco de dados, uma mensagem informativa é enviada para o autor dos dados, e uma notificação é enviada ao responsável pela aprovação final.

4) Caso o verificador clique em "Rejeitado", ele digita o motivo pelo qual o item foi rejeitado, e depois clica em "Enviar". Tal informação é registrada no banco de dados, e uma notificação é enviada para o autor dos dados, para que este revise os mesmos.

O fluxograma correspondente encontra-se na Figura 27.

Figura 27 - Fluxograma "Verificação de Itens Não Conformes"

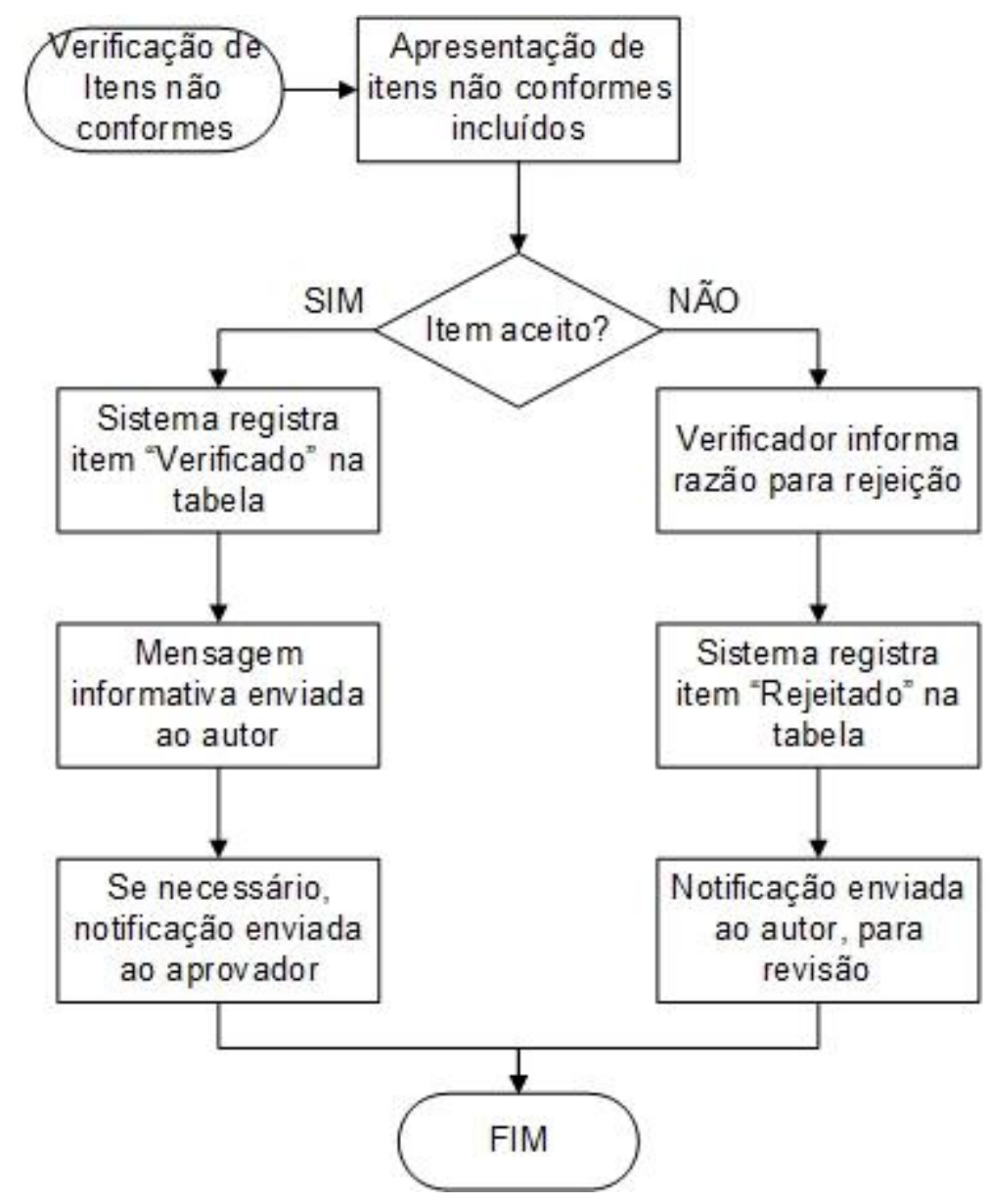


5.7.4 Página Aprovação de Itens Não Conformes

Itens a serem apresentados na página "Aprovação de Itens Não Conformes":

- Inicialmente, a página de Entrada;

- Depois, a página com o título "Aprovação de Itens não conformes";

- Caixa de texto com lista de itens a serem aprovados (até 5);

- Botão "Aprovado";

- Botão "Recusado";

- Botão "Cancelar";

- Botão "Sair";

- Caixa de texto "Item aprovado?" - incluir botões "Sim" e "Não";

- Caixa de texto "Item recusado?" - incluir botões "Sim" e "Não".

Operações elementares:

1) $O$ aprovador recebeu uma notificação de itens não conformes verificados. Após ser autorizado via login e senha, ele abre a página "Aprovação de Itens não conformes".

2) Os itens não conformes verificados aparecem na página. $O$ aprovador seleciona $\mathrm{o}$ item e analisa os dados. Na sequência, ele clica no botão "Aprovado" ou "Recusado".

3) Se o aprovador clicar em "Aprovado", a informação de "aprovado" é registrada no banco de dados, e mensagens informativas da aprovação final são enviadas para o autor dos dados e o verificador.

4) Caso o aprovador clique em "Recusado", ele digita o motivo pelo qual o item foi recusado, e depois clica em "Enviar". Tal informação é registrada no banco de dados, e notificações são enviadas para o autor dos dados e para 0 verificador, para revisão.

O fluxograma correspondente encontra-se na Figura 28. 
Figura 28 - Fluxograma "Aprovação de Itens Não Conformes"

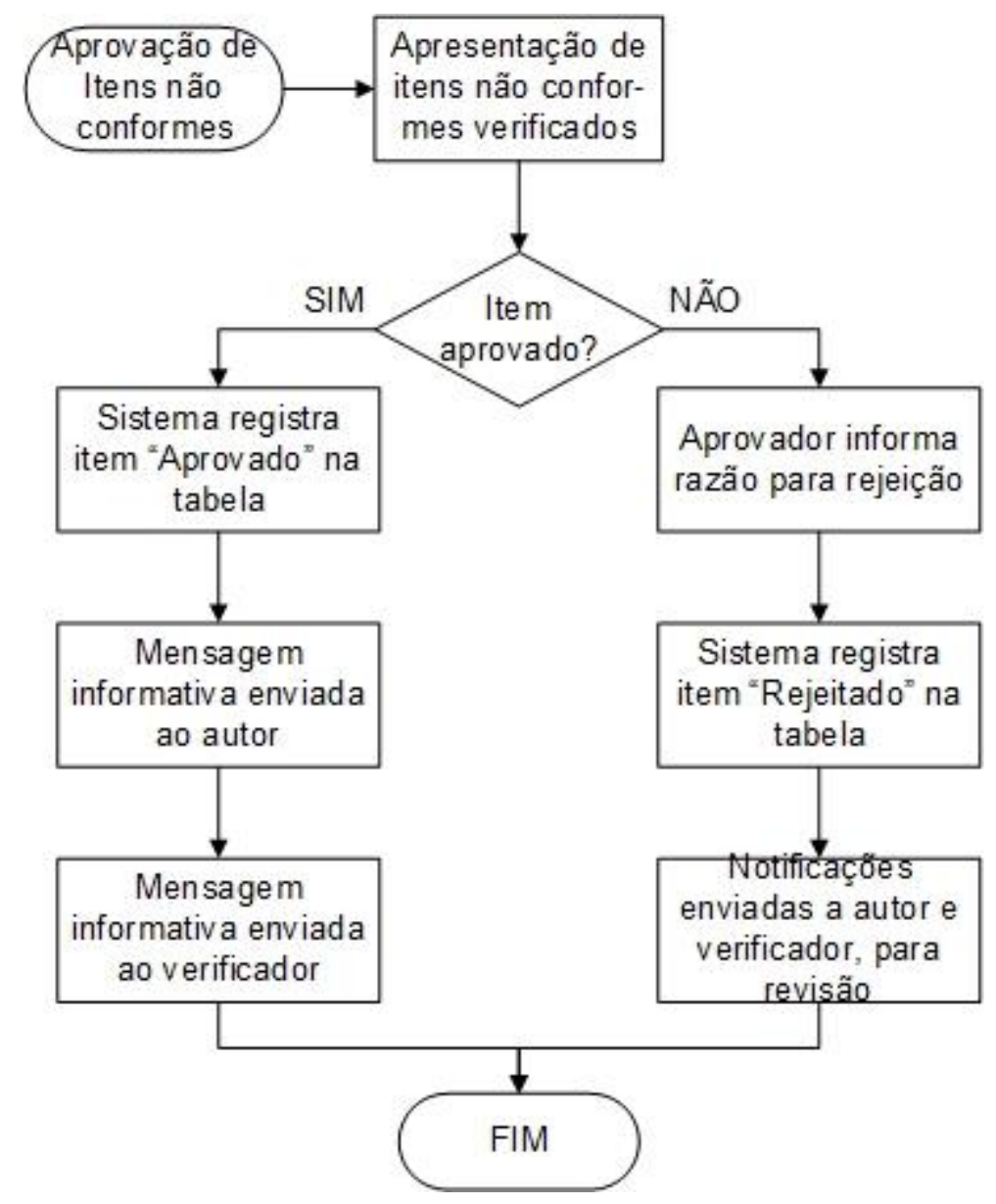

\subsection{Ações Corretivas}

Os requisitos da CNEN-NN-1.16 para este item estão especificados na seção 4.11 "Ações Corretivas". Esta seção possui uma única subseção. A seguir, a subseção 4.11 "Ações Corretivas":

4.11.1 Devem ser estabelecidas medidas para assegurar que condições adversas à qualidade, tais como, falhas, mau funcionamento, deficiências, desvios, materiais e equipamentos defeituosos e incorretos, e não conformidades, sejam identificadas e corrigidas.

4.11.2 Nas condições adversas à qualidade, deve ser determinada a causa de tais condições, através da utilização de um método disciplinado de investigação de causas, e adotada ação corretiva para evitar repetição.

4.11.3 A identificação de condições significativas, adversas à qualidade, juntamente com as respectivas causas e ações 
corretivas adotadas, devem ser documentadas e relatadas aos níveis apropriados de gerência. (CNEN, 2000).

O detalhamento realizado utilizando os itens correspondentes da regulação americana estão abaixo:

- Identificando as Condições Adversas à Qualidade

A condição adversa à qualidade deve ser identificada e documentada quando for identificada uma falha, mau funcionamento, deficiência, desvio, item com defeito ou não conformidade.

- Classificação das Condições Adversas à Qualidade

As condições adversas à qualidade devem ser classificadas quanto a sua importância e as ações corretivas devem ser tomadas de acordo.

Categorias de classificação devem ser estabelecidas para distinguir entre condições adversas à qualidade e condições significativamente adversas à qualidade.

- Notificando Condições Adversas à Qualidade

As condições adversas à qualidade devem ser documentadas, monitoradas e notificadas aos níveis administrativos adequados.

A gestão responsável deve realizar medidas corretivas assim que possível.

- Condições Significativamente Adversas à Qualidade

Critérios para a determinação de uma condição significativamente adversa à qualidade devem ser estabelecidos e documentados.

Condições significativamente adversas à qualidade devem ser prontamente documentadas e notificadas à gestão responsável pela situação e à sua administração superior.

Condições significativamente adversas à qualidade devem ser avaliadas pela organização de garantia da qualidade no caso de uma situação de interrupção de trabalho, para determinar se a interrupção é justificável. 
1. O departamento de garantia da qualidade deve emitir as ordens de interrupção de trabalho para a gestão responsável caso a necessidade para tal seja identificada.

2. O departamento de garantia da qualidade deve tomar as medidas adequadas para confirmar ou cancelar (em parte ou totalmente) a interrupção de trabalho emitida pelo departamento de garantia da qualidade, considerando a resolução do quadro significantemente adverso à qualidade.

A gerência responsável deve executar ação de investigação para determinar a extensão e o impacto da situação, e documentar os resultados.

A gerência responsável deve definir, documentar e concluir as ações corretivas.

A gerência responsável deve determinar e documentar a raiz do problema e tomar ações corretivas o mais breve possível para evitar sua reincidência.

- Acompanhamento

Devem ser estabelecidos processos para verificar a execução das ações corretivas associadas às condições significativamente adversas à qualidade.

\section{- Tendências na Qualidade}

Devem ser estabelecidos critérios para determinar as tendências adversas à qualidade.

Relatórios de não conformidades e condições adversas à qualidade devem ser avaliados para identificar as respectivas tendências.

A avaliação de tendências deve ser realizada de uma maneira e com a frequência que garantam a rápida identificação de tendências adversas à qualidade e auxiliem na identificação da raiz do problema.

As avaliações de tendências devem ser prontamente distribuídas aos responsáveis na CNEN para a análise e ação corretiva apropriada. 
As páginas a seguir são a de "Inclusão de Ações Corretivas" e a de "Consulta de Edição de Ações Corretivas", utilizadas pelo executor e pelo verificador; e "Verificação de Ações Corretivas", utilizada pelo gerente.

\subsubsection{Página Inclusão de Ações Corretivas}

Itens a serem apresentados na página "Inclusão de Ações Corretivas":

- Título "Inclusão de Ações Corretivas";

- Nome do usuário e data / horário de acesso;

- Caixa de entrada "Material com condição adversa à qualidade";

- Caixa de entrada "Tipo de condição (falha, mau funcionamento, deficiência, desvio, defeituoso ou incorreto, não conformidade)";

- Caixa de entrada "Departamento responsável";

- Caixa de entrada "A causa já foi investigada? (S/N)";

- Caixa de entrada "Causa do defeito";

- Caixa de entrada "Quem verificou / quando";

- Caixa de entrada "Ação corretiva a ser tomada";

- Caixa de entrada "Gerentes a serem informados";

- Botão "Salvar";

- Botão "Cancelar";

- Botão "Sair".

Operações elementares:

1) Digitar "Material em condição adversa à qualidade";

2) Escolher entre as opções "Tipo de condição (falha, mau funcionamento, deficiência, desvio, defeituoso ou incorreto, não conformidade)";

3) Digitar "Departamento responsável";

4) Escolher entre as opções "A causa já foi investigada? ( $/ \mathrm{N})$ ";

5) Caso positivo, digitar "Causa do defeito", "Quem verificou / quando" e "Ação corretiva a ser tomada";

6) Digitar "E-mail do gerente a ser informado". Apresentar mensagem "Deseja incluir mais algum gerente?". Caso positivo, salvar na tabela correspondente $\circ$ 
e-mail informado do gerente, limpar campo "E-mail do gerente a ser informado".

7) Caso negativo, clicar no botão "Salvar". O sistema grava os dados na tabela correspondente. Informativo é enviado para cada um dos Gerentes a serem informados.

O fluxograma correspondente encontra-se na Figura 29.

Figura 29 - Fluxograma "Inclusão de Ações Corretivas"

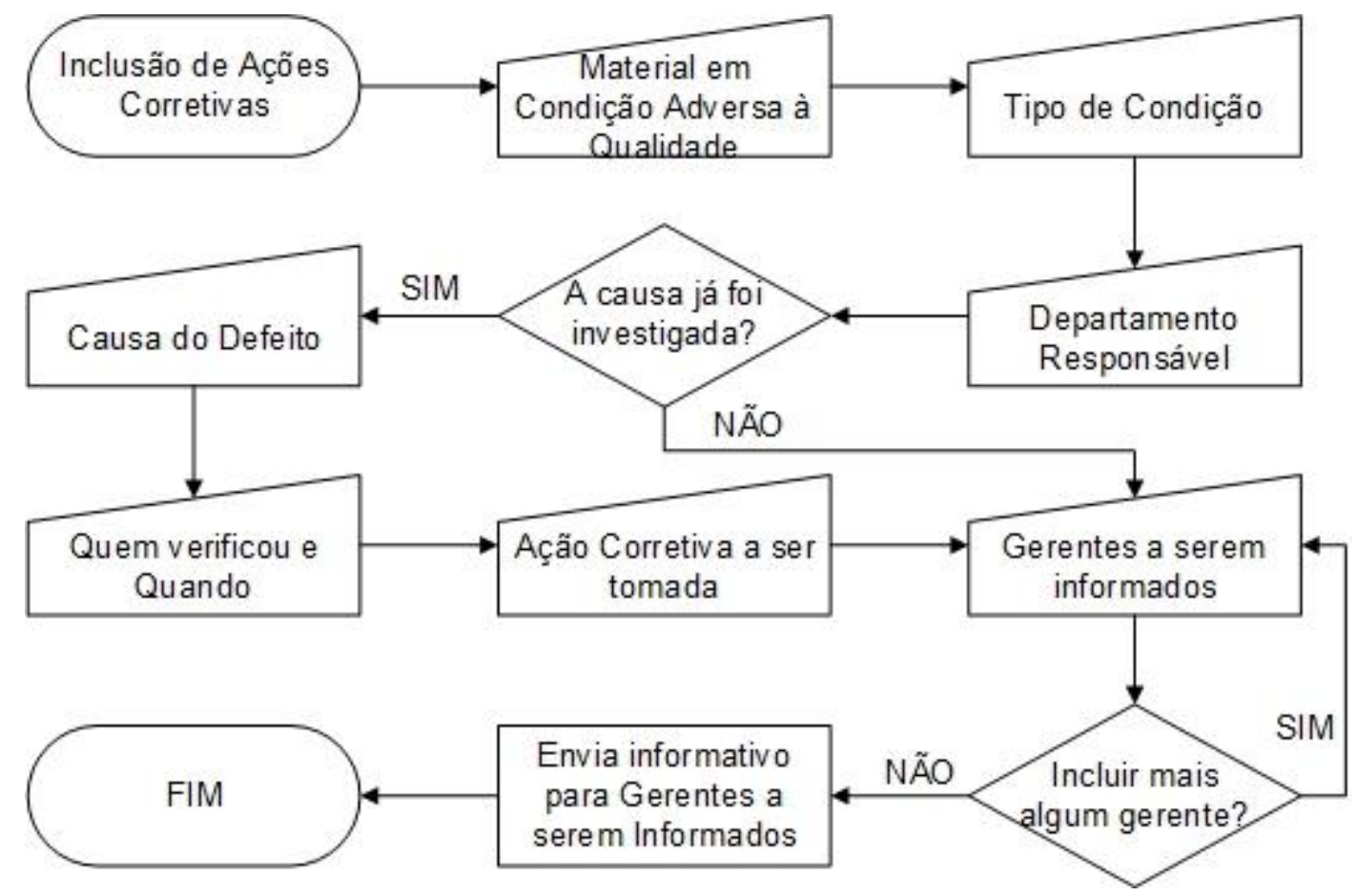

\subsubsection{Página Consulta e Edição de Ações Corretivas}

Itens a serem apresentados na página "Consulta e Edição de Ações Corretivas":

- Título "Consulta e Edição de Ações Corretivas";

- Nome do usuário e data / horário de acesso;

- Botão "Pesquisar";

- Botão de escolha "Pesquisa por Material em condição adversa à qualidade; Tipo de condição; Departamento responsável; Causa do defeito; Ação corretiva a ser tomada";

- Caixa de entrada "Dado a pesquisar"; 
- Caixa de entrada "Ação(ões) pesquisada(s)";

- Botão "Modificar";

- Botão "Sair".

Operações elementares:

1) Digitar uma palavra-chave correspondente à(s) ação(ões) corretiva(s) a ser(em) buscada(s);

2) Utilizar o botão de escolha para selecionar no campo de pesquisa a palavrachave digitada: por Material em condição adversa à qualidade; Tipo de condição; Departamento responsável; Causa do defeito; ou Ação corretiva a ser tomada. Clicar em "Pesquisar";

3) O sistema busca a palavra-chave na tabela correspondente. Caso não encontre nenhum item, aparece a mensagem "Nenhum item encontrado.". Retornar ao início da página "Consulta e Edição de Ações Corretivas".

4) $\mathrm{O}(\mathrm{s})$ item(ns) encontrado(s) é(são) listado(s) na Caixa de entrada "Ação(ões) Corretiva(s) Pesquisada(s)" (até 5 itens; para itens excedentes, cria-se uma barra de rolagem vertical à direita da lista);

5) Caso desejado, clicar em um dos itens listados e clicar em "Modificar";

6) Ao clicar em "Modificar", o sistema verifica qual item pesquisado foi selecionado; caso nenhum o tenha, aparece a mensagem "Nenhum item selecionado.".

7) Caso haja um item selecionado, o sistema traz os dados nos mesmos campos da página "Inclusão de Ações Corretivas", passíveis de modificações. O usuário modifica os valores de acordo e clica em "Salvar". O sistema atualiza a tabela. Retornar ao início da página "Consulta e Edição de Ações Corretivas". Notificações são enviadas aos Gerentes anteriormente informados.

8) Clicar em "Sair". O sistema fecha.

O fluxograma correspondente encontra-se na Figura 30. 
Figura 30 - Fluxograma "Consulta e Edição de Ações Corretivas"

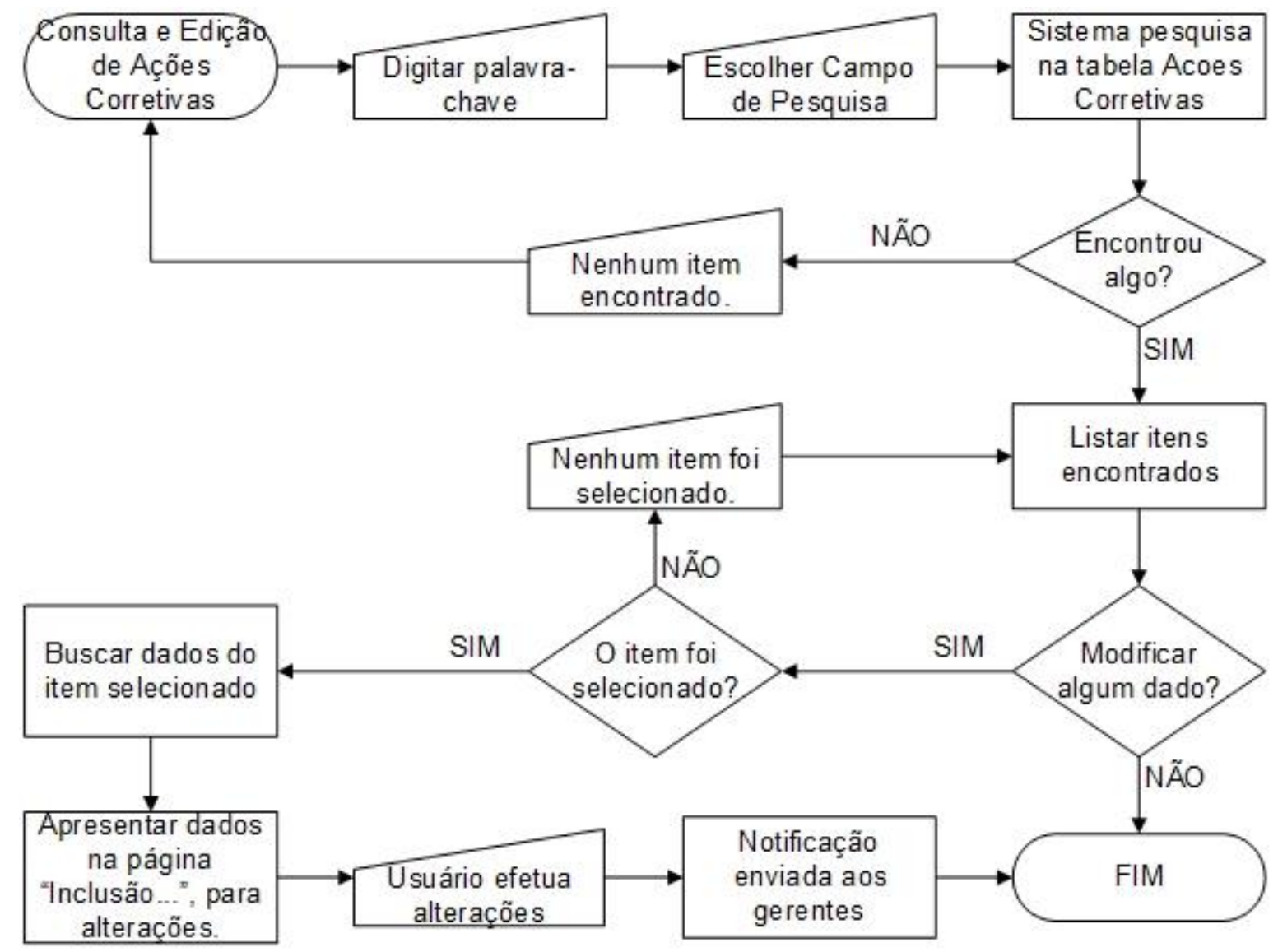

\subsubsection{Página Verificação de Ações Corretivas}

Itens a serem apresentados na página "Verificação de Ações Corretivas":

- Inicialmente, a página de Entrada;

- Depois, a página com o título "Verificação de Ações Corretivas";

- Caixa de texto com lista de itens a serem verificados (até 5);

- Botão "Aceito";

- Botão "Rejeitado";

- Botão "Cancelar";

- Botão "Sair";

- Caixa de texto "Item aceito?" - incluir botões "Sim" e "Não";

- Caixa de texto "Item rejeitado?" - incluir botões "Sim" e "Não". 
1) O gerente recebeu uma notificação de inclusão/modificação de ação(ões) corretiva(s). Após ser autorizado via login e senha, ele abre a página "Verificação de Ações Corretivas".

2) As ações corretivas incluídas/modificadas aparecem na página. O gerente seleciona o item e analisa os dados. Na sequência, ele clica no botão "Aceito" ou "Rejeitado".

3) Se o gerente clicar em "Aceito", a informação de "Aprovado" é registrada no banco de dados, uma mensagem informativa é enviada para o autor dos dados, e uma notificação é enviada ao autor dos dados.

4) Caso o gerente clique em "Rejeitado", ele digita o motivo pelo qual a ação corretiva foi rejeitada, e depois clica em "Enviar". Tal informação é registrada no banco de dados, e uma notificação é enviada para o autor dos dados, para que este revise os mesmos.

O fluxograma correspondente encontra-se na Figura 31.

Figura 31 - Fluxograma "Verificação de Ações Corretivas"

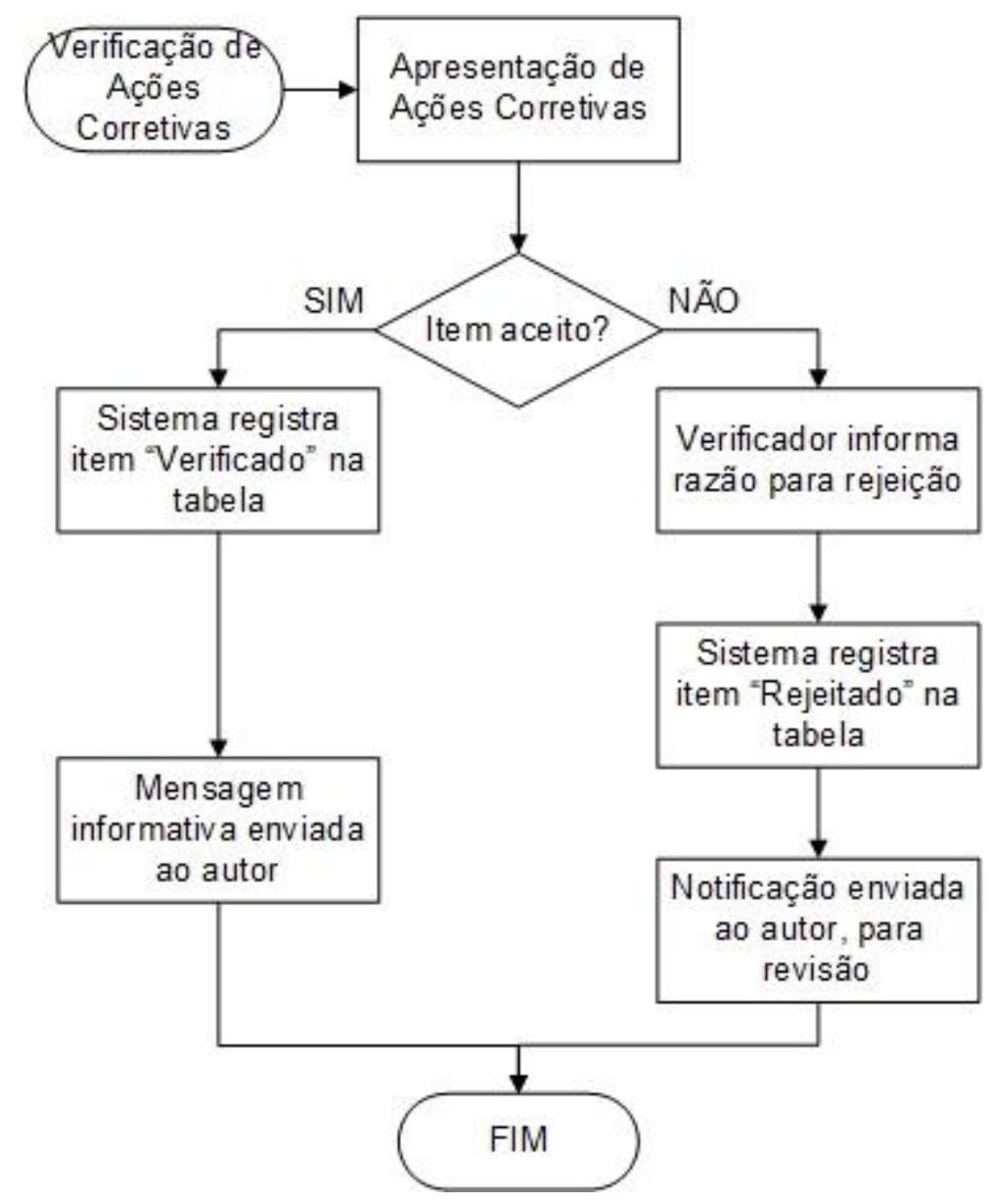




\subsection{Registros de Garantia da Qualidade}

Estes requisitos da CNEN-NN-1.16 estão especificados na seção 4.12 "Registros de Garantia da Qualidade". Esta seção possui duas subseções, referentes à preparação, coleta, arquivo e preservação dos registros. A seguir, a primeira subseção 4.12.1 "Preparação dos Registros":

4.12.1.1 Devem ser preparados, para o gerenciamento do Sistema de Garantia da Qualidade, registros adequados que representem evidência objetiva da qualidade.

4.12.1.2 Os registros devem incluir os resultados de análises, inspeções, testes, auditorias, monitoração do desempenho de trabalho, análises de materiais, notificações de alterações de campo, folhas diárias de operação da instalação, tratamentos de não conformidades, bem como dados correlatos, tais como qualificações de pessoal, procedimentos e equipamentos, reparos exigidos e outros documentos apropriados.

4.12.1.3 Os registros devem ser legíveis, completos $e$ identificáveis em relação ao item envolvido. (CNEN, 2000).

O detalhamento realizado utilizando os itens correspondentes da regulação americana é apresentado abaixo:

- Controle de Qualidade dos Registros

Os tipos de registros específicos de garantia da qualidade incluem, mas não estão limitados a:

1. Científicos, de engenharia, dados e agendas operacionais; cadernos

e livros de registro de laboratório e de campo; e documentos de redução de dados.

2. Resultados de revisões, inspeções, testes, auditorias e análise de material.

3. Monitoramento de desempenho no trabalho.

4. Procedimentos de manutenção e modificação, e resultados de inspeção.

5. Ocorrências comunicáveis.

6. Mudanças no programa de garantia da qualidade que reduzam os compromissos. 
7. Programa de computador com função de segurança ou isolamento de rejeitos.

8. Qualificação de pessoal e equipamento.

9. Qualificação de procedimentos especiais de processo.

10. Documentos tais como registros de projeto, desenhos, especificações, documentos de aquisição, procedimentos e relatórios de calibração, relatórios de revisão de projeto, relatórios de avaliação por pares, relatórios de não conformidades, relatórios de ações corretivas e desenhos "como construído".

11. Outros registros requeridos pelas condições operacionais de pré e pós-encerramento.

12. Registros de construção requeridos pelas respectivas associações competentes.

\section{- Gerando Registros Válidos de Garantia da qualidade}

Os documentos de execução devem identificar os documentos que virão a ser registros de garantia da qualidade, bem como a organização responsável pela apresentação dos registros de garantia da qualidade para o sistema de gerenciamento de registros.

O pessoal que gerar registros de garantia da qualidade deve assegurar que os mesmos sejam legíveis, precisos, completos, adequados para o trabalho realizado e identificáveis com o(s) item(ens) ou atividade(s) a que se aplicam.

O pessoal que lida com os registros de garantia da qualidade deve protegê-los de danos ou perda até que eles sejam enviados para o sistema de gerenciamento de registros.

Os documentos devem ser considerados registros válidos somente quando carimbados, rubricados ou assinados e datados por pessoal autorizado, ou autenticados de alguma outra forma. Esta autenticação pode ser uma declaração emitida por uma organização ou pessoal. Se a natureza do registro (ex.: meio magnético ou óptico) impedir a utilização de carimbo, rubrica ou assinatura, então outros meios de identificação do registro, desde que realizados por pessoal autorizado, devem ser permitidos. 
Assinaturas manuscritas não são necessárias se o documento estiver claramente identificado com uma declaração emitida por um indivíduo ou organização.

Registros de garantia da qualidade podem ser originais ou cópias.

Em seguida, a segunda subseção 4.12.2 "Coleta, Arquivo e Preservação dos Registros":

4.12.2.1 Deve ser estabelecido e implementado um sistema de registros, de acordo com procedimentos e instruções documentados.

4.12.2.2 O sistema de registros deve:

a) assegurar que sejam mantidos registros suficientes para fornecer evidência das atividades que influem na qualidade $e$ descrever condições pré-operacionais básicas conhecidas;

b) assegurar a identificação, coleta, indexação, arquivamento, manutenção e destino dos registros;

c) prover o arquivamento dos registros de tal maneira que sejam prontamente recuperáveis e mantidos em ambiente adequado para minimizar a deterioração ou danos e evitar perdas.

4.12.2.3 Os tempos de guarda dos registros, materiais e amostras de teste correspondentes, devem ser definidos por escrito.

4.12.2.4 Os registros que identificarem na instalação a condição de itens "como construído" devem ser mantidos pela ou para a organização responsável, durante a vida útil do item, desde a sua fabricação, ao longo da armazenagem, instalação e operação.

4.12.2.5 Para os registros não permanentes devem ser atribuídos tempos de guarda compatíveis com o tipo de registro envolvido.

4.12.2.6 O destino final dos registros deve ser definido de acordo com procedimentos escritos. (CNEN, 2000).

O detalhamento realizado utilizando os itens correspondentes da regulação americana segue abaixo:

- Apresentação de Registros de Garantia da Qualidade

Os registros de garantia da qualidade devem ser submetidos ao sistema de gerenciamento de registros para a recepção, processamento e armazenamento. 
- Recepção e indexação de Registros de Garantia da Qualidade

Um sistema de controle de recebimento de registros de controle da qualidade deve ser estabelecido conforme os seguintes requisitos:

1. Deve ser atribuída a um indivíduo ou organização a responsabilidade de receber os registros de garantia da qualidade. $O$ representante deve ser responsável pela organização e execução de um sistema de controle de recebimento de registros para armazenamento temporário e permanente.

2. Um método deve ser estabelecido para verificar se os registros de garantia da qualidade recebidos estão de acordo com os documentos de transferência.

3. Os registros de garantia da qualidade devem ser protegidos contra danos, deterioração ou perda, quando recebidos.

4. A legibilidade e integridade dos registros de garantia da qualidade devem ser verificadas.

5. O sistema de controle de recepção deve permitir uma avaliação atual e precisa do estado do registro de garantia da qualidade durante o processamento.

6. Os registros de garantia da qualidade devem ser indexados. $O$ sistema de indexação deve incluir, pelo menos: a localização dos registros de garantia da qualidade dentro do sistema de gerenciamento de registros; a identificação do item ou atividade relacionada à qual pertencem os registros de garantia da qualidade; os tempos de retenção de registros.

\section{- Corrigindo Informações nos Registros de Garantia da Qualidade}

As correções nos registros de garantia da qualidade, incluindo os documentos que se tornarão registros de garantia da qualidade, devem incluir as iniciais ou assinatura da pessoa autorizada a fazer a correção e a data em que a correção foi feita.

As correções nos registros de garantia da qualidade devem ser analisadas e aprovadas pelo autor original. Se a organização responsável por 
criar o registro não estiver mais disponível, uma nova organização responsável deve ser identificada e documentada.

\section{- Armazenamento e Preservação de Registros de Garantia da Qualidade}

Registros de garantia da qualidade devem ser armazenados e preservados em instalações de armazenamento pré-determinadas que atendam aos requisitos das normas, códigos e agências regulatórias aplicáveis, de acordo com a aplicação de documento aprovado que forneça:

1. Descrição da instalação de armazenamento.

2. Descrição do sistema de arquivamento a ser utilizado.

3. Método para verificar se os registros de garantia da qualidade recebidos estão de acordo com os documentos de transferência, e que os registros são legíveis.

4. Descrição dos controles que regem o acesso aos registros de garantia da qualidade, recuperação e remoção.

5. Método para inclusão de informações suplementares.

6. Método para disposição dos registros de garantia da qualidade substituídos.

Métodos de armazenamento devem ser desenvolvidos para evitar a deterioração dos registros de garantia da qualidade, conforme o seguinte:

1. A área de armazenamento deve ser construída e mantida de forma que seja minimizado o risco de danos ou destruição por desastres como inundações ou incêndios; condições ambientais, tais como temperatura e umidade altas e baixas; e infestações de insetos, fungos e roedores.

2. Métodos aprovados de arquivamento devem exigir que os registros de garantia da qualidade sejam devidamente guardados em fichários ou colocados em pastas ou envelopes para o armazenamento em armários de aço ou em prateleiras, em recipientes apropriados para a mídia de registro de garantia da qualidade que esteja sendo armazenada.

3. O arranjo do armazenamento deve fornecer a proteção adequada aos registros especiais de garantia da qualidade processados (por exemplo, radiografias, fotografias, negativos e microfilmes, e mídias 
eletrônica e magnética) para evitar danos advindos de umidade, temperatura, luz excessiva, campos eletromagnéticos ou empilhamento, de acordo com o tipo de registro de garantia da qualidade que esteja sendo armazenado.

4. A área de armazenamento deve ser protegida contra entrada não autorizada, furto e vandalismo.

- Recuperação de Registros de Garantia da Qualidade

O sistema de gerenciamento de dados deve garantir a recuperação dos registros de garantia da qualidade.

$\mathrm{O}$ acesso às instalações de armazenamento deve ser controlado. A lista deve ser mantida indicando os funcionários que possuem permissão de acesso aos registros de garantia da qualidade.

- Retenção de Registros de Garantia da Qualidade

- Registros Vitalícios de Garantia da Qualidade

Registros vitalícios de garantia da qualidade devem ser conservados e mantidos até que a licença seja modificada para a de fechamento permanente. Registros de garantia da qualidade vitalícios são aqueles que atendem a um ou mais dos seguintes critérios:

1. Aqueles que possuem valor significativo para demonstrar a capacidade de operação segura;

2. Aqueles que possuem valor significativo na manutenção, retrabalho, reparo, substituição ou modificação de um item;

3. Aqueles que possuem valor significativo em determinar a causa de um acidente ou avaria de um item;

4. Aqueles que fornecem dados de base necessários para a inspeção em serviço.

- Registros Não Permanentes de Garantia da Qualidade

Registros não permanentes de garantia da qualidade são aqueles que apresentam evidências de que uma atividade foi realizada em conformidade com os requisitos aplicáveis, mas que não cumprem com os critérios para caracterização como registros vitalícios de garantia da qualidade. 
1. Para registros de garantia da qualidade programáticos não permanentes, o início do período de retenção será após a conclusão da atividade.

2. Para registros não permanentes de garantia da qualidade de produtos, o início do período de retenção será após a conclusão da entrega.

\section{- Arquivamento de Registros de Garantia da Qualidade}

Os fornecedores devem apresentar à instalação de rejeitos radioativos os registros de garantia da qualidade que estão sendo armazenados provisoriamente pelo fornecedor e que estão sujeitos às exigências de arquivamento de registros. O período da apresentação será conforme os ciclos de registros sejam completados, ou conforme os itens sejam liberados para o embarque, ou conforme prescrito pelo comprador.

A organização do gerenciamento de registros deve inventariar a apresentação, confirmar recebimento e processar os registros de garantia da qualidade.

As organizações responsáveis devem identificar os registros de controle de qualidade no armazenamento temporário a serem arquivados como armazenamento de longo prazo no sistema de gerenciamento de registros.

- Unidades de armazenamento individuais de longo prazo

As unidades de armazenamento individuais para o armazenamento dos registros de garantia da qualidade devem satisfazer os seguintes requisitos de projeto e construção:

1. Concreto armado, bloco de concreto, alvenaria, construção ou similar.

2. Controle de drenagem para o chão e telhado. Se um dreno no chão existir, deve ser incluída uma válvula de retenção ou similar.

3. Resistência mínima de 120 minutos de porta corta-fogo, com batentes e estrutura.

4. Selante aplicado sobre as paredes como barreira contra a umidade ou condensação. 
5. Selante de superfície no chão, proporcionando superfície de desgaste dura para minimizar o pó de concreto.

6. Fundação selante e disposições para a drenagem.

7. Ar condicionado com sistema de filtro.

8. Sistema de proteção contra incêndio.

9. Penetrações limitadas à proteção contra incêndio, comunicação, iluminação e controles de temperatura e umidade. Vedações e válvulas em penetrações devem possuir resistência mínima de 2 horas de proteção contra incêndio.

Detalhes da construção devem ser revistos quanto à adequação da proteção dos registros, por uma pessoa competente na área técnica de proteção contra incêndio.

\section{- Unidades de Armazenamento Duplo}

Se o armazenamento duplo for utilizado ao invés do individual, os seguintes requisitos devem ser aplicados:

1. As unidades de armazenamento duplo para o armazenamento dos registros de garantia da qualidade devem disponibilizar instalações para cópias de cada registro, em locais suficientemente distantes um do outro, buscando eliminar a possibilidade de exposição a um perigo simultâneo.

2. Unidades de armazenamento duplo não devem ser obrigadas a cumprir com os requisitos de projeto e construção específicos para uma instalação de armazenamento individual de longo prazo, mas devem cumprir com os outros requisitos desta seção do SGQ.

\section{- Unidade de Armazenamento Provisório}

O armazenamento provisório deve garantir o armazenamento de registros de garantia da qualidade durante o processamento, revisão, ou utilização de arquivamento. 
- Substituição de Registros de Garantia da Qualidade

Organizações geradoras dos registros de garantia da qualidade devem desenvolver documentos que identifiquem os meios para a reposição, restauração ou substituição de registros de garantia da qualidade perdidos ou danificados.

Observação: Não há listas de operações, fluxogramas ou variáveis de banco de dados específicas desta seção, uma vez que os registros de garantia da qualidade fazem parte de todas as outras seções. É a informação necessária para a verificação e controle de conformidade de todos os requisitos.

\subsection{Auditorias}

Os requisitos da CNEN-NN-1.16 para este tipo de controle estão especificados na seção 4.13 "Auditorias". Esta seção possui duas subseções relacionadas a requisitos gerais e programação. A seguir, a primeira subseção 4.13.1 "Requisitos Gerais":

4.13.1.1 Deve ser utilizado um sistema de auditorias internas e externas, planejadas e documentadas para verificar, através de exames e avaliações, se os elementos aplicáveis do Sistema de Garantia da Qualidade foram estabelecidos, documentados e efetivamente implementados de acordo com as exigências especificadas.

4.13.1.2 As auditorias devem ser realizadas de acordo com procedimentos escritos.

4.13.1.3 As organizações responsáveis por auditorias devem selecionar e designar auditores qualificados, com conhecimento adequado das atividades a serem auditadas $e$ independentes de qualquer responsabilidade direta por essas atividades.

4.13.1.4 No caso de auditorias internas, as pessoas com responsabilidade direta pela execução das atividades a serem auditadas devem ser excluídas da seleção da equipe de auditoria.

4.13.1.5 Os resultados das auditorias devem ser registrados pelos auditores, em relatórios, e analisados pelas organizações com responsabilidade pela área auditada.

4.13.1.6 A gerência responsável pela área auditada deve providenciar, em tempo hábil, as ações corretivas necessárias, relativas às deficiências encontradas na auditoria. 
4.13.1.7 Devem ser providenciadas ações de acompanhamento para verificar se as deficiências constatadas na auditoria foram corrigidas. (CNEN, 2000).

O detalhamento realizado utilizando os itens correspondentes da regulação americana é apresentado abaixo:

\section{- Planejamento de Auditoria}

A organização da auditoria deve desenvolver e documentar um plano para cada auditoria individualmente. Este plano deve identificar a abrangência da auditoria, requisitos para sua execução, a equipe de auditoria, serviço a ser auditado, organizações a serem notificadas, documentos aplicáveis, agendamento da auditoria e implementação de documentos ou listas de verificação a serem utilizadas. As auditorias devem incluir avaliações técnicas sobre os procedimentos aplicáveis, instruções, atividades e itens.

O escopo de cada auditoria interna deve ser baseado na avaliação dos documentos de execução, atividades e itens a serem auditados; resultados de auditorias anteriores; natureza e frequência das deficiências previamente identificadas; e o impacto de mudanças significativas na equipe, organização, ou no SGQ.

\section{- Independência da Equipe de Auditoria}

A organização de auditoria deve selecionar e atribuir auditores independentes de qualquer responsabilidade direta pelo desempenho da atividade a ser auditada. A equipe de auditoria deve ter autoridade suficiente $\mathrm{e}$ liberdade de organização para tornar o processo de auditoria significativo e eficaz.

\section{- Seleção da Equipe de Auditoria}

Uma equipe deve ser identificada antes do início de cada auditoria. A equipe de auditoria deve incluir representantes do departamento de $G Q$ e, quando necessário, os especialistas técnicos aplicáveis.

Um auditor líder será nomeado para supervisionar a equipe, organizar e dirigir a auditoria, e coordenar a elaboração e emissão do relatório de auditoria.

Auditores líderes e demais auditores devem ser qualificados de acordo com os requisitos desta seção. Especialistas técnicos podem ser utilizados pela 
organização de auditoria para ajudar a avaliar a adequação dos processos técnicos.

No caso de auditorias internas, o pessoal com responsabilidade direta pela execução do serviço a ser auditado não pode estar envolvido na seleção da equipe de auditoria.

O auditor líder deve, antes de iniciar a auditoria, assegurar que 0 pessoal escolhido tenha experiência ou treinamento proporcional ao âmbito, complexidade ou especificidade do serviço a ser auditado.

\section{- Realização de Auditorias}

O líder da equipe de auditoria deve garantir que a equipe de auditoria esteja preparada antes de iniciar a auditoria.

As auditorias devem ser realizadas de acordo com procedimentos escritos ou listas de verificação. Elementos que tenham sido selecionados para a auditoria devem ser avaliados com relação aos requisitos especificados.

Evidências objetivas devem ser examinadas com o aprofundamento necessário para determinar se tais elementos estão sendo implementados de forma eficaz.

Os resultados da auditoria devem ser documentados pelo pessoal da auditoria, comunicados e revistos pela gestão com a responsabilidade pela área auditada. Condições que requeiram medidas corretivas imediatas devem ser comunicadas imediatamente à gestão da organização auditada.

Condições adversas à qualidade identificadas devem ser documentadas e corrigidas de acordo com a seção "Ações Corretivas".

\section{- Resposta à Auditoria}

A administração da organização ou atividade internamente auditada, incluindo os contratados principais, deve investigar as condições adversas à qualidade, e determinar e programar ações corretivas de acordo com a seção "Ações Corretivas".

A administração da organização ou atividade externamente auditada (exceto os contratados principais) deve investigar as condições adversas à qualidade, determinar e programar ações corretivas de acordo com a seção 
"Ações Corretivas", além de notificar por escrito a organização de auditoria sobre as medidas tomadas ou previstas.

Com relação aos resultados da auditoria, a administração da organização ou atividade auditada deve também identificar as medidas a serem utilizadas para prevenir a recorrência.

\section{- Avaliação das Respostas à Auditoria}

A adequação das ações corretivas propostas com base nos resultados da auditoria deve ser avaliada e aceita pela organização de auditoria antes do encerramento.

\section{- Ação de Acompanhamento}

Medidas de acompanhamento devem ser tomadas pela organização de auditoria para verificar que a ação corretiva com base nos resultados da auditoria venha a ser realizada em tempo hábil.

- Qualificação e Certificação da Equipe de Auditoria

O pessoal que realiza auditorias, incluindo auditores, especialistas técnicos e auditores líderes, deve ser qualificado e certificado de acordo com a regulamentação vigente.

Em seguida, a segunda subseção 4.13.2 "Programação":

4.13.2.1 As auditorias devem ser programadas com base na importância e no cronograma das atividades.

4.13.2.2 As auditorias programadas devem ser suplementadas por auditorias não programadas no caso de existir, pelo menos, uma das seguintes condições:

a) quando for necessária uma avaliação da eficácia do $S G Q$;

b) quando for preciso determinar a adequação do SGQ do fornecedor antes da celebração de um contrato ou da efetivação da ordem de compra;

c) quando, após a celebração de um contrato, houver decorrido tempo suficiente para a implementação do SGQ e for apropriado determinar se a organização está desempenhando adequadamente as funções de acordo com o prescrito no $P G Q$, na normalização aplicável e em outros documentos contratuais; 
d) quando forem efetuadas alterações importantes em áreas funcionais da Organização;

e) quando houver suspeição de que a qualidade de um item ou um serviço tenha sido comprometida devido a uma possível deficiência nos requisitos ou na implementação do $S G Q$;

f) quando for necessário verificar a implementação de ações corretivas. (CNEN, 2000).

O detalhamento realizado utilizando os itens correspondentes da regulação americana está abaixo:

- Agendamento de Auditorias

As auditorias devem ser realizadas em áreas em que as exigências dos documentos do $S G Q$ da instalação de gestão de rejeitos ou do fornecedor sejam aplicáveis. As seguintes áreas devem também ser consideradas para agendamento de auditorias:

1. Determinação de características do local que afetem sua adequação.

2. Preparação, revisão, aprovação e controle das primeiras aquisições.

3. Preparação e programas de treinamento.

4. Interface de controle entre a instalação de gestão de rejeitos radioativos e seus fornecedores.

5. Sistemas de ações corretivas, calibração e controle de não conformidades.

6. Relatórios de análise de segurança.

7. Desenvolvimento e controle de programa de computador com função de segurança ou isolamento de rejeitos.

- Agendamento de Auditorias Internas

Auditorias internas (ou seja, auditorias na instalação de gestão de rejeitos radioativos e contratados principais) devem ser coordenadas com o gerente responsável e agendadas de forma a fornecer cobertura, consistência e coordenação com os trabalhos em curso.

Auditorias internas devem ser agendadas com uma frequência compatível com a situação e a importância do trabalho. 
Auditorias internas devem ser agendadas para antes do início da vida útil do serviço e programadas para continuar em intervalos consistentes com o cronograma para a realização dos trabalhos.

Auditorias internas agendadas regularmente devem ser suplementadas por auditorias adicionais de assuntos específicos, quando necessário, para garantir uma adequada avaliação da conformidade e eficácia.

Auditorias internas de elementos do SGQ que verificam a conformidade e eficácia do SGQ da instalação de gestão de rejeitos devem ser realizadas a intervalos que não excedam 12 meses, ou pelo menos uma vez durante a vida útil do serviço, o que for menor.

Auditorias internas baseadas em desempenho devem ser realizadas em serviços selecionados para determinar a eficácia do SGQ da instalação de gestão de rejeitos radioativos.

\section{- Agendamento de Auditorias Externas}

Auditorias externas (auditorias em fornecedores) devem ser coordenadas com a administração do fornecedor e agendadas de forma a fornecer cobertura, consistência e coordenação com os trabalhos em curso.

As auditorias externas devem ser agendadas:

1. Para início antes da vida útil do serviço.

2. Para continuar em intervalos consistentes com o cronograma para realização do trabalho.

3. Com uma frequência compatível com a situação e importância do trabalho.

Auditorias externas de conformidade e eficácia devem ser realizadas a cada três anos ou, pelo menos, uma vez durante a vida útil do serviço, o que for menor. Auditorias externas regularmente agendadas devem ser suplementadas por auditorias adicionais de assuntos específicos, quando necessário, para garantir a adequada avaliação da conformidade ou eficácia (baseada em desempenho).

1. O período de auditoria deve ser iniciado quando a auditoria for realizada.

2. Auditorias externas anuais devem ser realizadas pelo comprador em um fornecedor ou outra organização externa sempre que o fornecedor 
ou organização externa não possuir um programa de auditoria aceito pelo comprador.

3. A auditoria inicial deve ser realizada quando o fornecedor tiver realizado trabalhos suficientes para demonstrar que sua organização esteja utilizando um programa de controle de qualidade que tenha 0 âmbito necessário para as compras feitas durante o período de auditoria.

4. Uma auditoria dos requisitos modificados deve ser realizada quando ocorrer uma alteração maior no âmbito do contrato, metodologia de trabalho, ou organização. Com esta auditoria deve-se iniciar um novo período de auditoria.

Auditorias externas podem não ser necessárias para itens adquiridos que são relativamente simples e padronizados em projeto, fabricação e testes, e adaptáveis a inspeções ou testes do produto final, padronizados ou automatizados para verificar as características de qualidade após a entrega. A justificativa para a não realização de auditorias nestes itens deve ser documentada.

Pesquisas pré-adjudicação, se aplicáveis, podem ser válidas na primeira auditoria trienal, desde que:

1. O fornecedor utilize o mesmo programa de garantia da qualidade em outros contratos propostos para o contrato do comprador.

2. A pesquisa pré-adjudicação satisfaça os mesmos elementos de auditoria e critérios que os utilizados na realização de uma auditoria trienal.

Os compradores da instalação de rejeitos radioativos incluem 0 departamento de rejeitos radioativos e seus contratados. Se mais de um comprador do departamento de rejeitos radioativos comprar de um único fornecedor, o comprador do departamento de rejeitos radioativos pode realizar ou organizar uma auditoria do fornecedor em seu próprio nome e de outros compradores do departamento de rejeitos radioativos, buscando reduzir o número de auditorias externas do fornecedor.

1. O âmbito desta auditoria deve satisfazer as necessidades de todos os compradores do departamento de rejeitos radioativos que venham a precisar do fornecedor. 
2. O relatório da auditoria deve ser distribuído aos compradores do departamento de rejeitos radioativos para quem a auditoria foi realizada.

3. Cada comprador do departamento de rejeitos radioativos que conte com os resultados da auditoria deve ser responsável pela adequação da mesma.

As páginas a seguir são a de "Inclusão de Auditorias" e a de "Consulta de Edição de Auditorias", utilizadas tanto pelo executor, como pelo verificador e pelo gerente.

\subsubsection{Página Inclusão de Auditorias}

Itens a serem apresentados na página "Inclusão de Auditorias":

- Título "Inclusão de Auditorias";

- Nome do usuário e data / horário de acesso;

- Caixa de entrada "Departamento a ser auditado";

- Caixa de entrada "Responsável pelo departamento";

- Caixa de entrada "Data agendada";

- Caixa de entrada "Periodicidade (dias)";

- Caixa de entrada "Equipe de auditoria";

- Caixa de entrada "Resultados";

- Caixa de entrada "Ações corretivas";

- Botão "Salvar";

- Botão "Cancelar";

- Botão "Sair".

Operações elementares:

1) Digitar "Departamento a ser auditado";

2) Digitar "Responsável pelo departamento";

3) Digitar "Data agendada";

4) Digitar "Periodicidade (dias)";

5) Digitar "Equipe de auditoria";

6) Digitar "Resultados"; 
7) Digitar "Ações corretivas";

8) Clicar no botão "Salvar". O sistema grava os dados na tabela correspondente. Informativo é enviado para o Responsável pelo departamento, avisando sobre a inclusão de nova auditoria.

O fluxograma correspondente encontra-se na Figura 32.

Figura 32- Fluxograma "Inclusão de Auditorias"

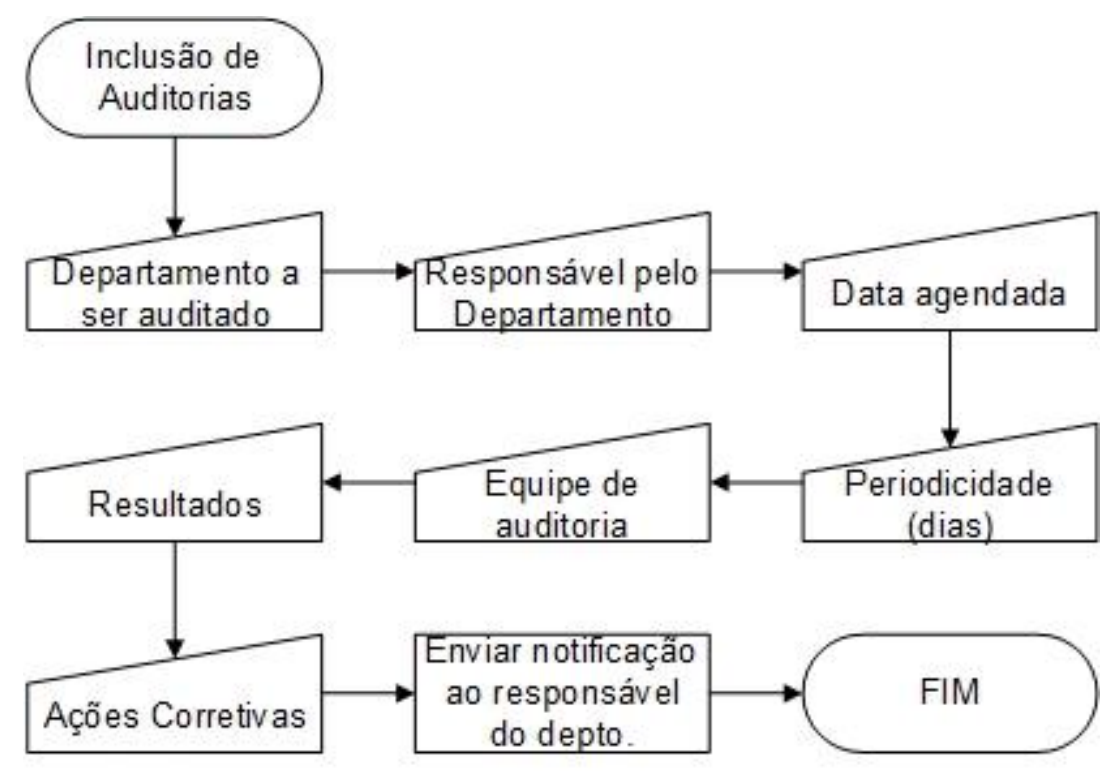

5.10.2 Página Consulta e Edição de informações sobre Auditorias

Itens a serem apresentados na página "Consulta e Edição de Informações sobre Auditorias":

- Título "Consulta e Edição de Informações sobre Auditorias";

- Nome do usuário e data / horário de acesso;

- Botão "Pesquisar";

- Botão de escolha "Pesquisa por Departamento a ser auditado; Responsável pelo departamento; Data agendada; Equipe de auditoria; Resultados; ou Ações corretivas";

- Caixa de entrada "Dado a pesquisar";

- Caixa de entrada "Auditoria(s) pesquisada(s)";

- Botão "Modificar";

- Botão "Sair". 
Operações elementares:

1) Digitar uma palavra-chave correspondente à(s) auditoria(s) a $\operatorname{ser}(\mathrm{em})$ buscada(s);

2) Utilizar o botão de escolha para selecionar no campo de pesquisa a palavrachave digitada: por Tipo de item não conforme; Método de identificação; Departamento; ou Características quanto ao estado. Clicar em "Pesquisar";

3) O sistema busca a palavra-chave no campo de pesquisa selecionado na tabela correspondente. Caso não encontre nenhum item, aparece a mensagem "Nenhum item encontrado.". Retornar ao início da página "Consulta e Edição de Informações sobre Auditorias".

4) $\mathrm{O}(\mathrm{s})$ item(ns) encontrado(s) é(são) listado(s) na Caixa de entrada "Auditoria(s) Pesquisada(s)" (até 5 itens; para itens excedentes, cria-se uma barra de rolagem vertical à direita da lista);

5) Caso desejado, clicar em um dos itens listados e clicar em "Modificar";

6) Ao clicar em "Modificar", o sistema verifica qual item pesquisado foi selecionado; caso nenhum o tenha, aparece a mensagem "Nenhum item selecionado.".

7) Caso haja um item selecionado, o sistema traz os dados nos mesmos campos da página "Inclusão de Auditorias", passíveis de modificações. O usuário modifica os valores de acordo e clica em "Salvar". O sistema atualiza a tabela. Retornar ao início da página "Consulta e Edição de Informações sobre Auditorias". É enviada ao responsável pelo departamento notificação de modificação de auditoria.

8) Clicar em "Sair". O sistema fecha.

O fluxograma correspondente encontra-se na Figura 33. 
Figura 33 - Fluxograma "Consulta e Edição de Auditorias"

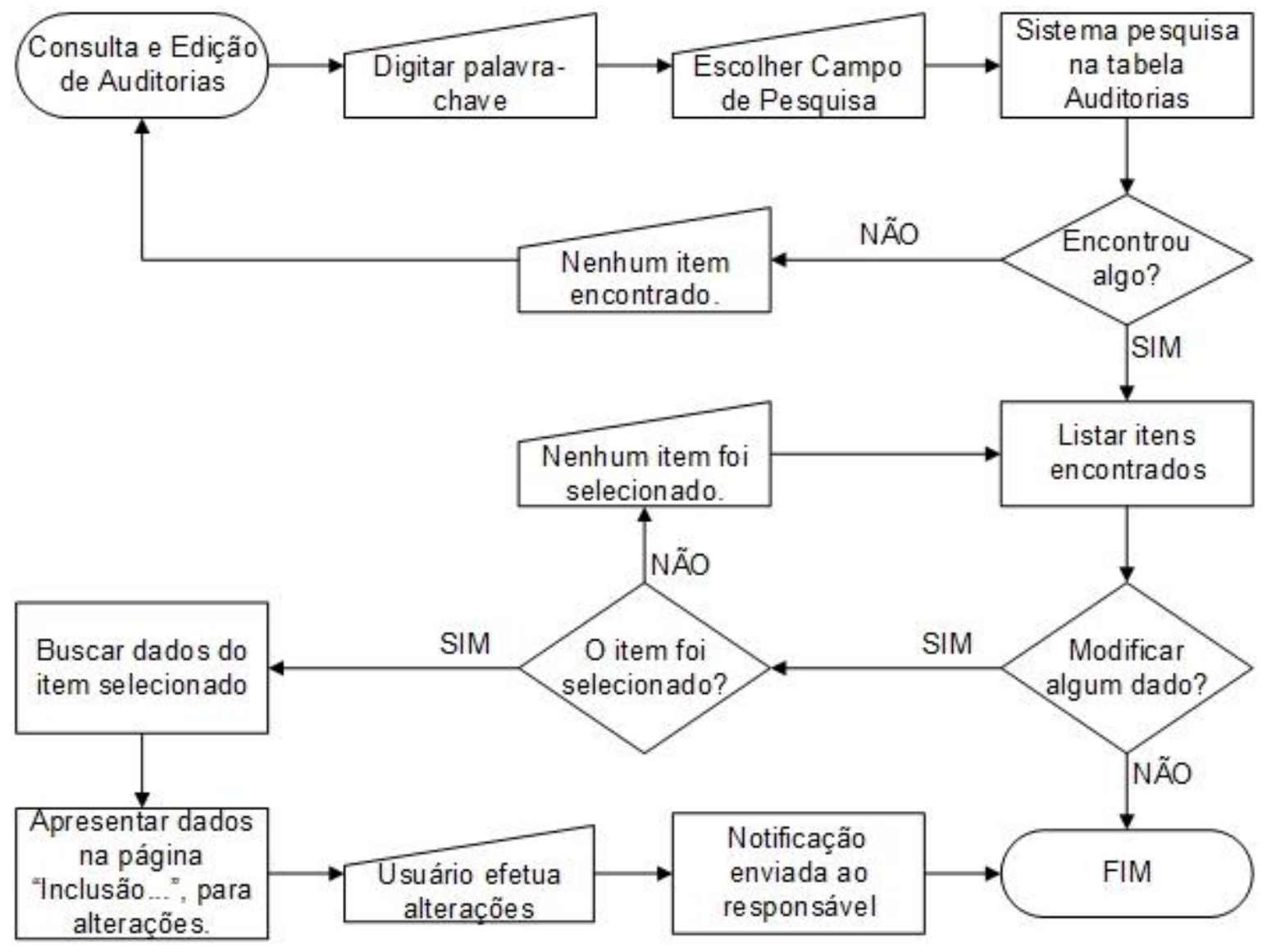




\section{DISCUSSÃO}

Conforme apresentado na seção 3.1 , as leis brasileiras inicialmente desenvolvidas para gerir a área nuclear no país estabeleceram a CNEN para posterior aperfeiçoamento do controle regulatório de tal área. Verificou-se que a regulamentação para gestão de instalações radiativas no Brasil foi baseada na mesma estrutura das respectivas leis americanas. Como a informação tecnológica para o surgimento e evolução dos empreendimentos nucleares no Brasil foi inicialmente fornecida pelos Estados Unidos a partir de seu programa "Átomos para a Paz" na década de 1950, que visava o aperfeiçoamento da área nuclear em ações pacíficas, entende-se o porquê de os responsáveis pela preparação da regulamentação utilizarem como matéria-prima a legislação daquele país.

A análise do regulamento americano DOE/RW-0333P e sua correlação com o regulamento brasileiro CNEN-NN-1.16 demonstraram não apenas a semelhança de estrutura entre elas, mas também, devido a sua maior especificidade, que as informações advindas da regulamentação americana abordam uma variedade maior de situações em uma instalação de rejeitos radioativos, o que termina por minimizar ocasiões de ambiguidade nas interpretações da execução das regras.

O mapeamento de processos através da preparação dos fluxogramas baseados nas condições para controle descritas na CNEN-NN-1.16, junto das respectivas operações elementares, ou passo a passo, analisam tais processos em nível das atividades mais elementares, visando facilitar o entendimento no momento de sua utilização prática, o que permitiria a um indivíduo com menos conhecimentos da área nuclear, inclusive um programador de computação, uma melhor compreensão dos procedimentos importantes para a segurança a serem controlados.

O objetivo de mapear os processos de forma a manter a conformidade com a regulamentação CNEN-NN-1.16 foi realizado, porém somente em nível descritivo, apresentando o funcionamento geral do processo. A situação de abrangência se manteve, pois tal como esta regulamentação é direcionada a todo tipo de instalação nucleoelétrica e radiativa, também o são os fluxogramas de processo. Os níveis analítico e executável somente seriam viáveis após o 
emprego deste mapeamento de processos em situações mais específicas de uma instalação radiativa.

A validação dos mapeamentos de processos pode ser obtida apenas considerando que a confiança nos resultados dos processos seja aumentada em função de redução da incerteza dos mesmos. Isto é conseguido através de melhorias contínuas dos processos, à medida que novos dados e informações se tornem disponíveis e sejam incorporados aos mesmos em progressivas modelagens.

No entanto, a técnica de mapeamento de processos por meio de fluxogramas pode apresentar deficiências na priorização e identificação de falhas devido à quantidade de informações envolvida. Com isso, outras ferramentas como o SIPOC e o FTA podem utilizadas para detectar as atividades críticas para o processo, conhecer a sequência do fluxo de atividades e entender de forma clara e rápida o processo (ANDRADE; MARRA; LEAL; MELLO, 2012).

Alguns métodos para verificação e validação de processos informatizados para controle de rejeitos são descritos em dois artigos sobre avaliações de desempenho no projeto do repositório da Planta-Piloto de Isolamento de Rejeitos Radioativos do Departamento de Energia dos Estados Unidos, no estado de New Mexico (FROELICH; OGDEN; BYLE, 2000; FROELICH; WILLIAMSON; OGDEN, 2000). Os métodos propostos são por etapas de desenvolvimento do código do programa, ou então por fases do ciclo de vida do programa. Um outro documento desenvolvido pelas Tecnologias de Segurança Nacional dos EUA (NST, 2007) apresenta um plano de garantia da qualidade do programa GoldSim $^{\circledR}$, que realiza o controle das áreas 3 e 5 dos locais de gestão de rejeitos radioativos no estado de Nevada. Tais métodos poderiam ser utilizados em trabalhos futuros, com os processos mapeados de acordo com os da gestão de rejeitos radioativos. 


\section{CONCLUSÃO}

Este trabalho foi desenvolvido para ser uma ferramenta de orientação para cumprimento dos requisitos regulatórios especificados na regulamentação nacional CNEN-NN-1.16. Além disto, buscou-se trazer da regulamentação americana um conjunto de dados que, através de correspondências e analogias, seguisse a mesma estrutura desta regulamentação nacional, mas que fosse dirigida para a área mais específica da gestão de rejeitos radioativos.

Embora algumas situações precisem ser verificadas ou mais desenvolvidas em outros trabalhos, considera-se que os objetivos do presente trabalho foram cumpridos. Ainda que as pesquisas realizadas tenham encontrado poucos artigos acadêmicos relacionados com o tema, as documentações legais e normativas localizadas deste e de outros países permitiram que fosse feita uma sistematização da literatura sobre o tema e posterior utilização de métodos e técnicas para o desenvolvimento da pesquisa científica.

Recomendam-se trabalhos futuros para verificar quais métodos seriam mais indicados para mitigação dos erros e validação do mapeamento de processos apresentado neste trabalho, quando aplicado em uma instalação de rejeitos radioativos. 


\section{REFERÊNCIAS BIBLIOGRÁFICAS}

ABDEL RAHMAN, R.O.; EL-KAMASH, A.M.; SHEHATA, F.A.; EL-SOUROUGY, M.R. Planning for a Solid Waste Management Quality Assurance Program in Egypt. Quality Assurance Journal, v. 11, p. 53-59, 2007.

AGUILAR-SAVÉN, R.S. Business process modeling: Review and framework. International Journal of Production Economics, v.90, n. 2, p. 129-149, 2004.

AMERICAN SOCIETY OF MECHANICAL ENGINEERS. Nuclear Quality Assurance. New York City, 2017. (ASME-NQA-1-2017).

ANDRADE, G.E.V.; MARRA, B.A.; LEAL, F.; MELLO, C.H.P. Análise da Aplicação Conjunta das Técnicas SIPOC, Fluxograma e FTA em uma Empresa de Médio Porte. In: ENCONTRO NACIONAL DE ENGENHARIA DE PRODUÇÃO, 32., 1518 de outubro, 2012, Bento Gonçalves, RS, Resumos...

ASSOCIAÇÃO BRASILEIRA DE NORMAS TÉCNICAS. Guia de termos e expressões utilizados na Normalização. Rio de Janeiro, 2012. Disponível em: $<$ http://portalmpe.abnt.org.br/component/content/article/18-bibliotecadigital/guias/76-guia-de-termos-e-expressoes>. Acesso em jan. 2018.

BECKMERHAGEN, I.A.; BERG, H.P.; HARNACK, K. Quality assurance for safety-related components in a waste repository. Journal of Quality in Maintenance Engineering, v. 2, n. 2, p. 38-49, 1996.

BIZAGI. Bizagi - The Digital Business Platform. 2018. Disponível em: $<$ https://www.bizagi.com/pt>. Acesso em: jan. 2018.

BRASIL. Lei no 4.118, de 27 de agosto de 1962. Dispõe sobre a política nacional de energia nuclear, cria a Comissão Nacional de Energia Nuclear, e dá outras providências. Diário Oficial da União, Brasília, DF, 19 set.1962. Disponível em: <http://www.planalto.gov.br/ccivil_03/leis/L4118compilada.htm>. Acesso em: jan. 2018.

BRASIL. Lei no 6.189, de 16 de dezembro de 1974. Altera a Lei no 4.118, de 27 de agosto de 1962, e a Lei oㅜ 5.740, de 1 de dezembro de 1971. Diário Oficial da União, Brasília, DF, 17 dez.1974. Disponível em: <http://www.planalto.gov.br/ccivil_03/leis/L6189.htm>. Acesso em: jan. 2018.

BRASIL. Constituição (1988). Constituição da República Federativa do Brasil. Brasília, DF: Senado Federal: Centro Gráfico, 1988, 292 p.

BRASIL. Lei oㅜ 7.781, de 27 de junho de 1989. Dá nova redação aos artigos 2º 10 e 19 da Lei no 6.189, de 16 de dezembro de 1974, e dá outras providências. Diário Oficial da União, Brasília, DF, 28 jun.1989. Disponível em: <http://www.planalto.gov.br/ccivil_03/leis/L7781.htm>. Acesso em: jan. 2018. 
BRASIL. Lei no 10.308 de 20 de novembro de 2001. Dispõe sobre a seleção de locais, a construção, o licenciamento, a operação, a fiscalização, os custos, a indenização, a responsabilidade civil e as garantias referentes aos depósitos de rejeitos radioativos, e dá outras providências. Diário Oficial da União, Brasília, DF, 21 nov.2001. Disponível em:

<http://www.planalto.gov.br/ccivil_03/leis/LEIS_2001/L10308.htm>. Acesso em: jan. 2018.

BRASIL. Decreto no 5.935, de 19 de outubro de 2006. Promulga a Convenção Conjunta para o Gerenciamento Seguro de Combustível Nuclear Usado e dos Rejeitos Radioativos. Diário Oficial da União, Brasília, DF, 20 de outubro de 2006. Disponível em: <https://www.planalto.gov.br/ccivil_03/_Ato20042006/2006/Decreto/D5935.htm>. Acesso em: jan. 2018.

BRITISH STANDARDS INSTITUTION (BSI). Specification for a total quality assurance programme for nuclear instalations. Londres, 1996. (BS 5882:1996).

COMISSÃO NACIONAL DE ENERGIA NUCLEAR. Seleção e Escolha de Locais para Depósitos de Rejeitos Radioativos. Rio de Janeiro: CNEN, 1990. (CNENNE-6.06). Disponível em:

<http://appasp.cnen.gov.br/seguranca/normas/pdf/Nrm606.pdf>. Acesso em: jan. 2018.

COMISSÃO NACIONAL DE ENERGIA NUCLEAR. Garantia da Qualidade para a Segurança de Usinas Nucleoelétricas e Outras Instalações. Rio de Janeiro: CNEN, 2000. (CNEN-NN-1.16). Disponível em:

$<$ http://appasp.cnen.gov.br/seguranca/normas/pdf/Nrm116.pdf>. Acesso em: jan. 2018.

COMISSÃO NACIONAL DE ENERGIA NUCLEAR. Critérios para Aceitação e Deposição de Rejeitos Radioativos de Baixo e Médio Níveis de Radiação. Rio de Janeiro: CNEN, 2002. (CNEN-NE-6.09). Disponível em:

$<$ http://appasp.cnen.gov.br/seguranca/normas/pdf/Nrm609.pdf>. Acesso em: jan. 2018.

COMISSÃO NACIONAL DE ENERGIA NUCLEAR. Gerência de Rejeitos Radioativos de Baixo e Médio Níveis de Radiação. Rio de Janeiro: CNEN, 2014. (CNEN-NN-8.01). Disponível em:

<http://appasp.cnen.gov.br/seguranca/normas/pdf/Nrm801.pdf>. Acesso em: jan. 2018.

COMISSÃO NACIONAL DE ENERGIA NUCLEAR. Licenciamento de Depósitos de Rejeitos Radioativos de Baixo e Médio Níveis de Radiação. Rio de Janeiro: CNEN, 2014. (CNEN-NN-8.02). Disponível em:

<http://appasp.cnen.gov.br/seguranca/normas/pdf/Nrm802.pdf>. Acesso em: jan. 2018.

COMISSÃO NACIONAL DE ENERGIA NUCLEAR. Quem Somos. 2015.

Disponível em: <http://www.cnen.gov.br/quem-somos>. Acesso em: jan. 2018. 
COMISSÃO NACIONAL DE ENERGIA NUCLEAR. Licenciamento de Instalações Radiativas. Rio de Janeiro: CNEN, 2017. (CNEN-NE-6.02). Disponível em: < http://appasp.cnen.gov.br/seguranca/normas/pdf/Nrm602.pdf>. Acesso em: jan. 2018.

DAMELIO, R. The Basics of Process Mapping. 2.ed. Boca Raton, FL: CRC Press, 2011.

ERRERA, J.; TISON, J.L. Acceptance and tracking of waste packages from nuclear power plants at the Centre de l'Aube. In: IAEA-CSP--6/C, 2001, Proceedings... Disponível em: <https://wwwpub.iaea.org/MTCD/publications/PDF/csp_006c/PDF-Files/paper-25.pdf>. Acesso em: jan. 2018.

ESCUELA DE ORGANIZACIÓN INDUSTRIAL (EOI). Análisis de los Registros de Garantía de Calidad de Enresa. 2011. Disponível em:

$<$ https://www.eoi.es/es/file/16960/download?token=ou1FVCmr>. Acesso em: Jan. 2018.

FROEHLICH, G.K.; OGDEN, H.C.; BYLE, K.A. Software quality assurance for the 1996 performance assessment for the Waste Isolation Pilot Plant. Reliability Engineering and System Safety, v. 69, p. 421-427, 2000.

FROEHLICH, G.K.; WILLIAMSON, C.M.; OGDEN, H.C. Computational environment and software configuration management of the 1996 performance assessment for the Waste Isolation Pilot Plant. Reliability Engineering and System Safety, v. 69, p. 429-436, 2000.

GUROCK. TestRail: Quality Assurance Management Software for your QA Team. 2018. Disponível em: <http://www.gurock.com/testrail/>. Acesso em: jan. 2018.

INSTITUTO DE PESQUISAS ENERGÉTICAS E NUCLEARES. Quem somos. 2012. Disponível em:

$<$ https://www.ipen.br/portal_por/portal/interna.php?secao_id=1141>. Acesso em: jan. 2018.

INTERNATIONAL ATOMIC ENERGY AGENCY. Manual on Training, Qualification and Certification of Quality Assurance Personnel. Viena, 1986. (Technical Reports Series 262).

INTERNATIONAL ATOMIC ENERGY AGENCY. Regulatory Inspection of the Implementation of Quality Assurance Programmes: A Manual. Viena, 1989. (Technical Reports Series 296).

INTERNATIONAL ATOMIC ENERGY AGENCY. Implementation of Quality Assurance Corrective Actions: A Manual. Viena, 1990. (Technical Reports Series 317). 
INTERNATIONAL ATOMIC ENERGY AGENCY. Grading of Quality Assurance Requirement: A Manual. Viena, 1991. (Technical Reports Series 328).

INTERNATIONAL ATOMIC ENERGY AGENCY. Quality Assurance Integrated Training Packages: A Manual. Viena, 1992. (Technical Reports Series 340).

INTERNATIONAL ATOMIC ENERGY AGENCY. Application of Quality Assurance to Radioactive Waste Disposal Facilities. Viena, 1996. (IAEATECDOC-895).

INTERNATIONAL ATOMIC ENERGY AGENCY. The IAEA Online Information Resource for Radioactive Waste Management. Viena, 2002. Disponível em: $<$ http://newmdb.iaea.org/>. Acesso em: jan. 2018.

INTERNATIONAL ATOMIC ENERGY AGENCY. Radioactive Waste Management Glossary. 2003 Edition. Viena, 2003.

INTERNATIONAL ATOMIC ENERGY AGENCY. The Management System for Facilities and Activities - Safety Requirements. Viena, 2006. (Safety Standards Series No. GS-R-3).

INTERNATIONAL ATOMIC ENERGY AGENCY. Radioactive Waste Management Information Systems - Radioactive Waste Management Registry (RWMR). Viena, 2015. Disponível em: $<$ https://www.iaea.org/OurWork/ST/NE/NEFW/TechnicalAreas/WTS/informationsystems.html>. Acesso em: jan. 2018.

INTERNATIONAL ATOMIC ENERGY AGENCY. Nuclear Safety Conventions. Viena, 2017. Disponível em: < https://www.iaea.org/topics/nuclear-safetyconventions>. Acesso em: jan. 2018.

LASER, M. Modifications of radioactive waste management as a consequence of quality assurance and quality control. Shorter communication, 1991. Disponível em: <http://archive.icheme.org/cgibin/somsid.cgi?session=226237D\&type=header\&record=2250 $>$. Acesso em: jan . 2018.

MASTERCONTROL. Quality Assurance (QA) Software Systems. Disponível em: <https://www.mastercontrol.com/quality-management-software/qualityassurance $>$. Acesso em: jan. 2018.

MOHAMED, Y.T. Quality Assurance Manual for Low Level Radioactive Waste Disposal Facility. In: WM'07 CONFERENCE, February 25 - March 01, 2007, Tucson, AZ: USA. Proceedings... Disponível em: <http://www.wmsym.org/archives/2007/pdfs/7069.pdf>. Acesso em: 10 jan. 2018.

NATIONAL SECURITY TECHNOLOGIES (NST). Software Quality Assurance Plan for GoldSim ${ }^{\circledR}$ Models Supporting the Area 3 and Area 5 Radioactive Waste Management Site Performance Assessment Program. 2007. Disponível 
em: <https://inis.iaea.org/search/search.aspx?orig_q=RN:39107452>. Acesso em: jan. 2018.

OFFICE OF CIVILIAN RADIOACTIVE WASTE MANAGEMENT. Quality Assurance Requirements and Description. EUA, 2009. (DOE/RW-0333P, Revision 21).

ORGANIZAÇÃO PARA A COOPERAÇÃO E DESENVOLVIMENTO ECONÔMICO (OCDE). Le contrôle réglementaire de la gestion des déchets radioactifs: panorama de 15 pays membres de l'AEN. Paris: OCDE, 2004.

OUZOUNIAN, G. Low-level radioactive waste management: The French case. In: LLRWM Workshop, Washington, D.C., EUA, Outubro 24-25, 2016, Proceedings... Disponível em: <http://dels.nas.edu/resources/staticassets/nrsb/miscellaneous/LLWMgmtWorkshop/Ouzounian_LLWmanagementFrenchCase.pdf>. Acesso em: jan. 2018.

PMQM. Curso de Gerenciamento de Processos de Negócio, 2018. Disponível em:

$<$ http://www.pmqm.com.br/index.php?option=com_content\&view=article\&id=88:cur so-de-gerenciamento-de-processos-de-negocio\&catid=3:noticias $>$. Acesso em: jan. 2018.

SILVER, B. BPMN Method and Style: A levels-based methodology for BPM process modeling and improvement using BPMN 2.0. Aptos, CA: CodyCassidy Press, 2009.

U.S. DEPARTMENT OF ENERGY. NQA-1: An Overview for Federal Project Directors. 2011. Disponível em: <https://energy.gov/management/downloads/nqa1 pdf>. Acesso em: set. 2015.

U.S. FEDERAL REGISTER. Nuclear Safety Management, 10 CFR Part 830 , p.1813, 2001. Disponível em: <https://www.gpo.gov/fdsys/pkg/FR-2001-0110/pdf/01-608.pdf>. Acesso em: jan. 2018. 